\title{
Prevention of obesity in childhood
}

Citation for published version (APA):

Ernst, M. A. B. (2015). Prevention of obesity in childhood. [Doctoral Thesis, Maastricht University]. Maastricht University. https://doi.org/10.26481/dis.20150415me

Document status and date:

Published: 01/01/2015

DOI:

10.26481/dis.20150415me

Document Version:

Publisher's PDF, also known as Version of record

\section{Please check the document version of this publication:}

- A submitted manuscript is the version of the article upon submission and before peer-review. There can be important differences between the submitted version and the official published version of record.

People interested in the research are advised to contact the author for the final version of the publication, or visit the DOI to the publisher's website.

- The final author version and the galley proof are versions of the publication after peer review.

- The final published version features the final layout of the paper including the volume, issue and page numbers.

Link to publication

\footnotetext{
General rights rights.

- You may freely distribute the URL identifying the publication in the public portal. please follow below link for the End User Agreement:

www.umlib.nl/taverne-license

Take down policy

If you believe that this document breaches copyright please contact us at:

repository@maastrichtuniversity.nl

providing details and we will investigate your claim.
}

Copyright and moral rights for the publications made accessible in the public portal are retained by the authors and/or other copyright owners and it is a condition of accessing publications that users recognise and abide by the legal requirements associated with these

- Users may download and print one copy of any publication from the public portal for the purpose of private study or research.

- You may not further distribute the material or use it for any profit-making activity or commercial gain

If the publication is distributed under the terms of Article $25 \mathrm{fa}$ of the Dutch Copyright Act, indicated by the "Taverne" license above, 


\section{PREVENTION \\ OF OBESITY \\ IN CHILDHOOD}
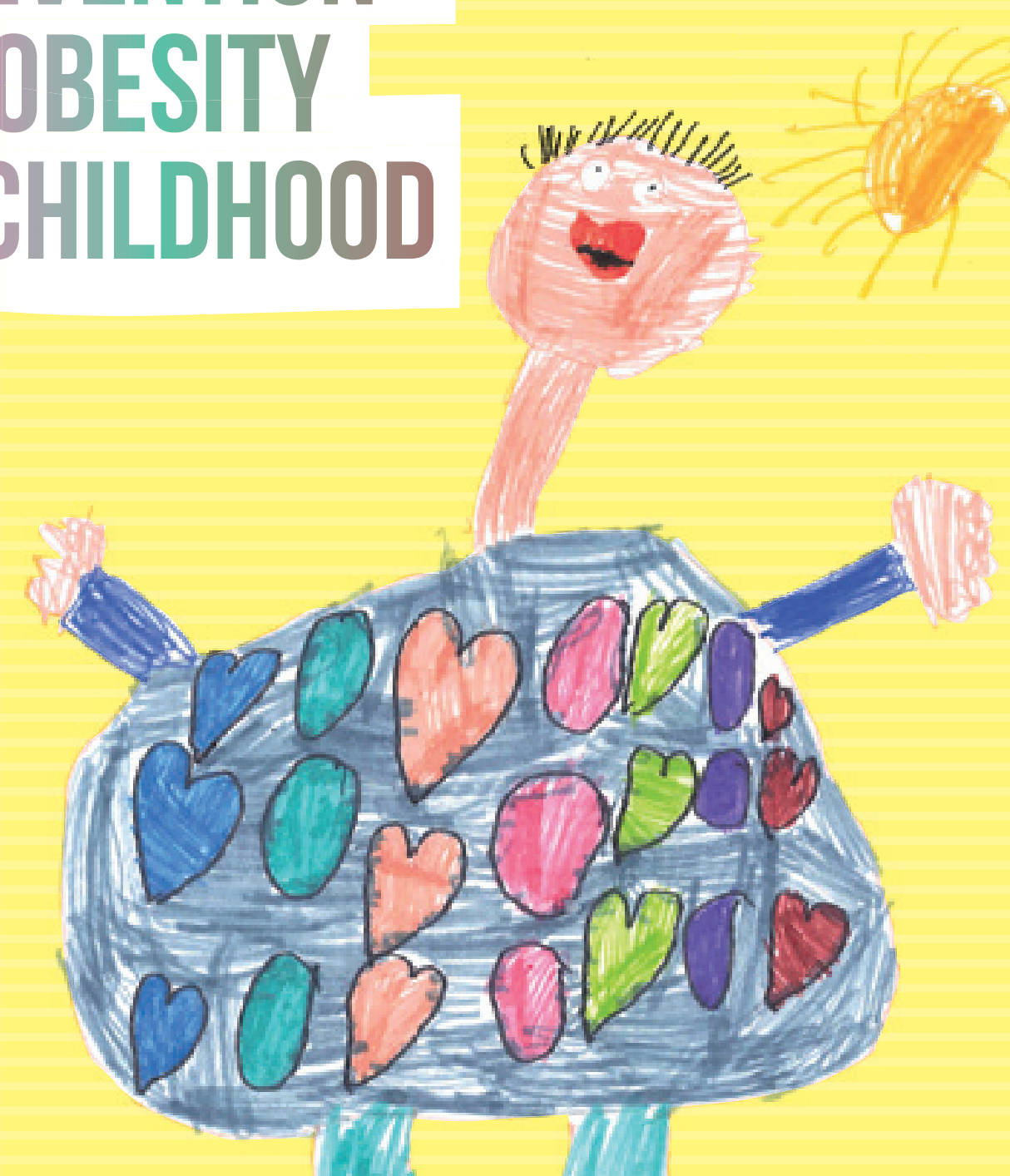

MANON ERNST 



\section{Prevention of obesity in childhood}

Manon Alice Bertine Ernst 
The research presented in this thesis was conducted at the Academic Collaborative Centre for Public Health Limburg.

The financial support for the publication of this thesis was kindly provided by Pierre Gubbels, Joep Gubbels and Fagron.

(C) Copyright Manon Ernst, Maastricht 2014.

Vormgeving en realisatie: Grafische Dienstverlening, Facilitair Bedrijf azM

Cover design and illustrations: Floor en Lotte Houppermans

ISBN: 978-90-822614-5-5 


\title{
Prevention of obesity in childhood
}

\author{
PROEFSCHRIFT
}

ter verkrijging van de graad van doctor aan de Universiteit Maastricht, op gezag van de Rector Magnificus, Prof. dr. L.L.G. Soete, volgens het besluit van het College van Decanen, in het openbaar te verdedigen, op woensdag 15 april 2015, om 14:00 uur

door

Manon Alice Bertine Ernst 


\section{Promotor}

Prof. Dr. L.J.I. Zimmermann

\section{Copromotor}

Dr. W.J.M. Gerver en Dr. M.A.H.B.M. van der Hoeven

\section{Beoordelingscommissie}

Prof. Dr. F.J.M. Feron (voorzitter)

Prof. Dr. J.H.A. Bosma

Prof. Dr. C. Noordam, Radboud Universitair Medisch Centrum, Nijmegen

Prof. Dr. P.J.J. Sauer, Universitair Medisch Centrum, Groningen

Prof. Dr. M.S. Westerterp 
Aan mijn ouders

"Ut kump wie ut kump, ut geet wie ut geet, ut hat nog ummer good gegange..." 


\section{Contents}

Chapter 1 General introduction 9

Chapter 2 Obesity in childhood: a secular trend or an epidemic disease? 23

Chapter 3 Change in total body water as a predictive tool for growth $\quad 41$ hormone treatment response

Chapter 4 Body proportions in small for gestational age children after $\quad 57$ receiving growth hormone treatment

Chapter 5 A prediction model to prevent abnormal weight in childhood

Chapter 6 The use of a prediction model to prevent abnormal weight in childhood in the Youth Health Care Practice

$\begin{array}{lll}\text { Chapter } 7 & \text { Discussion } & 105\end{array}$

$\begin{array}{ll}\text { Summary / Samenvatting } & 117\end{array}$

$\begin{array}{ll}\text { Dankwoord } & 127\end{array}$

$\begin{array}{ll}\text { Curriculum vitae } & 133\end{array}$ 



\section{CHAPTER 1}

GENERAL INTRODUCTION

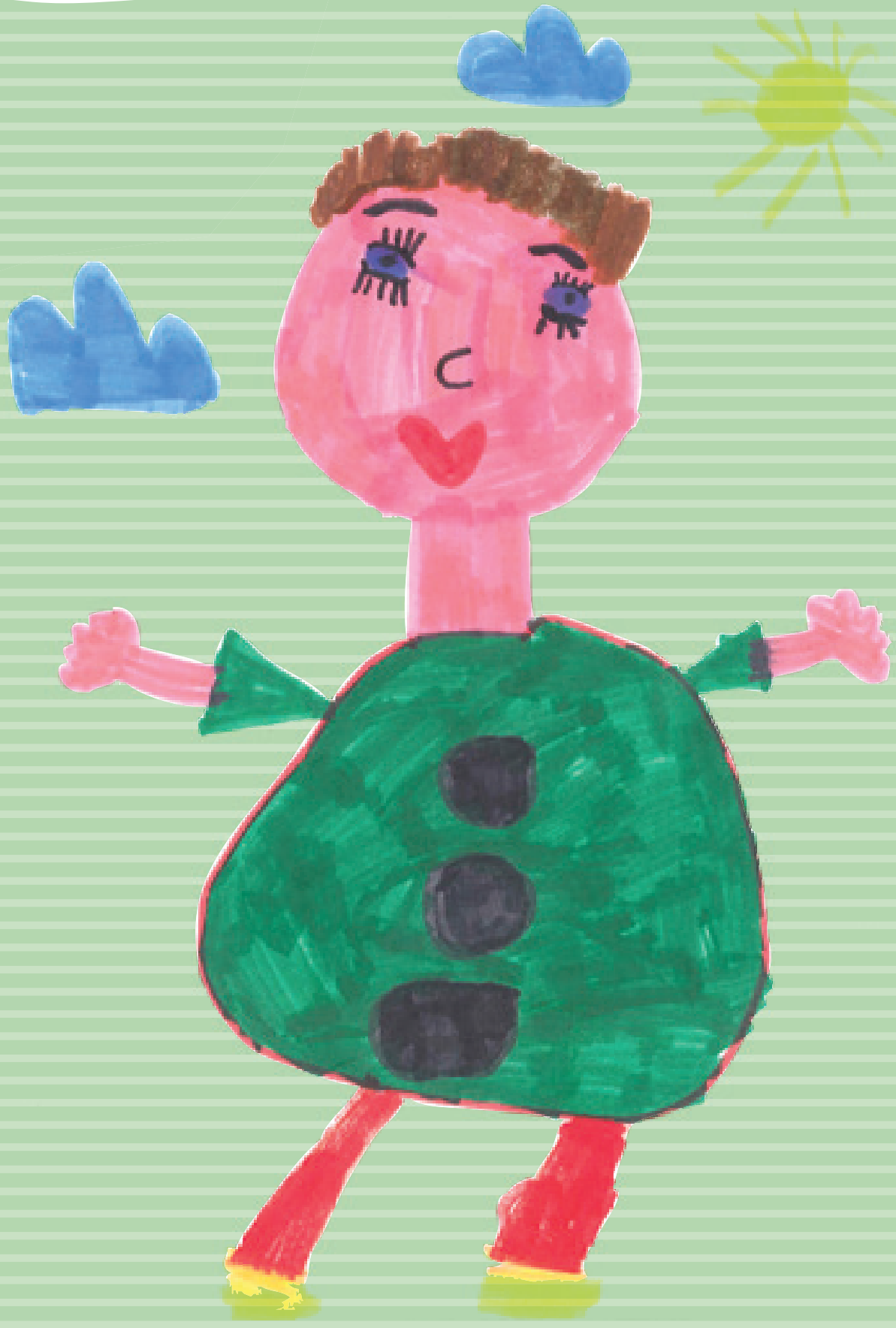


CHAPTER 1 


\section{Aim of the thesis}

The aim of this study is to gain better insight into the development of obesity in childhood, in the anthropometric and metabolic consequences and the possibilities to prevent obesity already in the first years of life. Therefore, the longitudinal data of height and weight in a healthy Dutch population are analyzed to make a better assessment on the risk on developing obesity. Growth patterns and the change in body composition of individual children during the first 4 years of age are evaluated to create a prediction model of normal growth. The use of the prediction model can be applied to prevent obesity and thereby play an essential tool in the Youth Health Care Practice. Prevention of obesity is important because it is a risk factor for the development of the metabolic syndrome with the well-known cardiovascular pathology. Not only obesity in childhood but also intrauterine growth retardation is known as the origin of the metabolic syndrome. Small for gestational age (SGA) children are treated with recombinant human growth hormone (rhGH) from the age of four years onwards, not only to improve their height, but also for metabolic reasons. From earlier studies it is known that rhGH has a positive effect on the metabolism ${ }^{1}$. Therefore, we investigated the growth and change in body composition of SGA children, treated with rhGH. The results of this study gain some insight in the change of body composition and can be used to compare SGA children with children developing obesity. The question arises if there is a common ground for the development of the metabolic syndrome.

\section{Obesity}

During the last decades the prevalence of overweight increased at a fast rate, not only in adults but also in children. In $19807 \%$ of children (6-11 years) in the United States were obese in comparison to $18 \%$ in 2010. In adolescents (12-19 years) this increase is even worse: $5 \%$ was obese in 1980 and $18 \%$ in $2010^{2,3}$. Worldwide, the number of overweight children under the age of 5 years is estimated over 42 million. Recently, high prevalence of overweight and obesity was reported in children and adolescents in several developing countries: 41.8\% in Mexico, 22.1\% in Brazil, $22.0 \%$ in India, and $19.3 \%$ in Argentina 4 .

The question arises, if the increasing incidence of overweight is actually due to a change in lifestyle and feeding habits or as a result of the secular trend ${ }^{5}$. A secular trend for height describes the change in physical development from one generation to the next and is an important parameter for the socioeconomic conditions of a society. With regard to weight it is questionable if the phenomenon of a secular trend is also a positive development in society, reflecting the improved socioeco- 
nomic conditions or a negative development because of an increasing incidence of diseases related to obesity.

Obesity can be defined as an overload of fat mass in the body. The degree of overweight is determined by the Body Mass Index (BMI) calculated by weight (kg) divided by the square height $\left(\mathrm{m}^{2}\right)$. Adolphe Quetelet, a Belgian statistician, introduced the BMI. Therefore the BMI is also called the Quetelet index ${ }^{6}$. The World Health Organization defines a BMI between $18.5 \mathrm{~kg} / \mathrm{m}^{2}$ and $25 \mathrm{~kg} / \mathrm{m}^{2}$ as healthy while overweight and obesity are defined as a BMI $>25$ and BMI $>30$ respectively. One speaks of morbid obesity in case of a BMI $>40 \mathrm{~kg} / \mathrm{m}^{2}$. With regard to children the value of the BMI is age dependent and thereby the cut-off point of abnormal weight may differ from adults. The Ponderal Index (PI) is comparable to the BMI, but the mass is normalized with the third power of body height rather than the second power. It is used in infants because their body form is more cubic instead of oblong. Another approach is to depict on a graph weight versus height whereby the two measurements are used independent of age. It makes an estimation of weight more reliable in the case of extreme tall or small children. To date, often-used method is the measurement of waist circumference as an estimate of the abdominal fat mass. The measurement of skinfolds is applied to measure subcutaneous fat but is less accurate in obese children because of the restricted possibility of verification.

It must be taken into consideration that the BMI does not make a difference between fat mass and fat-free mass. The fat-free mass represents all tissues except fat. From the fat-free mass only the muscle mass changes in relation to fat mass during the development of obesity. This difference can be estimated by measuring Total Body Water (TBW), the amount of water in the body. TBW is measured by the Deuterium dilution method or doubly labeled water (DLW) method. DLW is a the stable isotope of hydrogen and according to the Maastricht protocol ${ }^{7}$ the fat-free mass can be calculated by

$C_{1} \times V_{1}=C_{2} \times V_{2}$

$\mathrm{C}_{1}=$ concentration of the label in the ingested fluid

$\mathrm{V}_{1}=$ volume of the dose

$\mathrm{C}_{2}=$ concentration of the tracer in the sample

$\mathrm{V}_{2}=$ distribution volume in the body

Due to the exchange of the tracer with non-aqueous substances in the body, $V_{2}$ has to be divided by 1.04 to determine TBW.

To interpret total body water in individuals who differed in height, the results are corrected for height as TBW/height ${ }^{2}$. 
Adipose tissue expanding in the obese state synthesizes and secretes metabolites and signaling proteins like leptin, adiponectin, and tumor necrosis factor-alpha. These factors are known to alter insulin secretion and sensitivity and even cause insulin resistance 8 . The most important consequences of insulin resistance in children include increased incidence of type 2 diabetes, atherogenic dyslipidemia and arterial hypertension, which lead to increased cardiovascular risk. In case of female pediatric patients a higher incidence of polycystic ovary syndrome (PCOS) is observed ${ }^{9}$. Besides, there are numerous medical comorbidities associated with obesity in childhood. Nonalcoholic fatty liver disease (NAFLD) is increasingly prevalent in pediatric age individuals, in parallel with increasing obesity, and can lead to liver inflammation, fibrosis and even cirrhosis ${ }^{10}$.

Not only severe physical consequences of obesity can be seen, but also psychosocial problems are obvious like stigmatization and discrimination ${ }^{11}$. Obese children have more problems with playing sports with their peers and may suffer from bullying ${ }^{12}$. They may also develop a low self-esteem and a poor body image. It is generally agreed that being obese, or even being overweight, is a highly stigmatized condition. There is a considerable discussion in the literature on the stigma of obesity and the way that obese people are treated in western society, from childhood teasing and bullying ${ }^{13}$, avoidance by others ${ }^{14}$, and misplaced humour ${ }^{15}$. Obese children are at risk to become isolated, miss the connection with peers and may drop out of society.

There are a couple of predictive risk factors to develop obesity. In general, children with a BMI $\geq 95^{\text {th }}$ percentile have a high risk for adult obesity ${ }^{16}$. Also an early age of adiposity rebound (the moment of increase of the BMI) is an important predictor for obesity in adolesence ${ }^{17}$. Exposure to maternal obesity, with or without gestational diabetes, having a high birth weight ${ }^{18}$, but also low birth weight, together with catch-up growth, is associated with a significant risk of adult obesity. Studies including randomized controlled trials consistently show that higher protein intake during infancy is associated with the development of obesity. Lack of breastfeeding was also associated with obesity in many observational studies ${ }^{19}$. The hypothesis that breastfeeding could have a protective effect against obesity is supported by epidemiological evidence, but literature data are still controversial. If this hypothesis is confirmed, it will represent one more advantage of breastfeeding, as well as a new "weapon" to fight obesity. The potentially implicated mechanisms still have to be clarified. Breastfeeding involves several aspects, such as the amount of food intake, composition of the food, time of introduction of solid foods and development of regulatory eating mechanisms. Also behavioral aspects related to the mother-child relationship and formations of eating habits are important aspects of breastfeeding ${ }^{20}$. 
In developing countries determinants of childhood obesity include high socioeconomic status, residence in metropolitan cities, female gender, unawareness and false beliefs about nutrition, marketing by transnational food companies, increasing academic stress, and poor facilities for physical activity ${ }^{4}$ In the past, in the developed countries obesity was seen particularly in individuals with high socioeconomic status, in the wealthy population, because of excess food intake. To date, obesity is particularly seen in the lower income groups. In an attempt to account for this fact are more fast food intake, less exercise, more playing computer games and watching television.

Causes for obesity are health styles and also genetic backgrounds are mentioned. Some gene defects have been described which could be related to a predisposition to obesity. Particularly FTO (Fat mass and obesity-associated protein also known as alpha-ketoglutarate-dependent dioxygenase FTO), MC4R (Melanocortin receptor 4), and TMEM18 (Transmembrane protein 18) loci are described in the development of obesity. MC4R mutations are associated with inherited human obesity. They were found in heterozygotes, suggesting an autosomal dominant inheritance pattern. However, based on other research and observations, these mutations seem to have an incomplete penetrance and some degree of codominance. It has a prevalence of $1-2.5 \%$ in people with BMI's > 30, making it the most common known genetic defect predisposing people to obesity ${ }^{21}$. Although some genes have been found for pediatric obesity, there is still a lot more to be learned, and the future involves looking at rare variants, gene-by-gene and gene-by-environment interactions, and epigenetic factors ${ }^{22}$.

\section{Metabolic syndrome}

The concern about overweight in childhood is based on the observation that it leads to obesity in adulthood and thereby to a risk of developing the metabolic syndrome, not only with regard to adults but also with regard to children. The metabolic syndrome has become one of the major health problems of our times. Associated obesity, dyslipidemia, atherosclerosis, hypertension, and type 2 diabetes add up to shorten life spans, whereas hyperandrogenism with polycystic ovarian syndrome affect the quality of life and fertility of increasing numbers of women ${ }^{23}$.

In 2007, the International Diabetes Federation (IDF) proposed a definition of pediatric metabolic syndrome using age-specific diagnostic criteria: (1) children aged 6-10 years who are obese (defined as waist circumference $\geq 90^{\text {th }}$ percentile) and have other relevant risk factors such as family history of cardiometabolic disease and (2) children aged 10-16 years who are obese and meet the adult metabolic syndrome criteria for triglycerides (TGs), HDL-cholesterol (HDL-C), blood pressure (BP), and glucose concentrations ${ }^{24}$. 
During the last decades it became evident that the origin of the metabolic syndrome has to be found in childhood and not in adulthood. Originally it was proven by Barker that SGA children are at risk for developing this syndrome in adulthood. Besides, to date the first signs of the syndrome can also be recognized in obese children who are still young. The metabolic impact of obesity is determined by the pattern of lipid partitioning. Lipid storage in insulin sensitive tissues (such as liver and muscle) and in the visceral compartment is associated with a typical metabolic profile characterized by elevated free fatty acids and inflammatory cytokines alongside reduced levels of adiponectin. This combination can lead to peripheral insulin resistance and to endothelial dysfunction. The combination of insulin resistance and early atherogenesis drives the development of altered glucose metabolism and of cardiovascular disease ${ }^{17}$. Important cardiovascular risk factors in children with obesity are high blood pressure, high cholesterol level, high LDL-cholesterol level and low HDL cholesterol level.

An association has been described between asthma and obesity, especially during puberty. One of the possible mechanisms is that obesity represents a proinflammatory state, and leptin levels influence Th1 cytokine responses ${ }^{23}$.

Also skin disorders can be a consequence of the metabolic syndrome like acanthosis nigricans. Acanthosis nigricans is associated to hyperinsulinemia. Common sites of involvement include the axillae, posterior region of the neck, antecubital fossae, and groins ${ }^{23}$. The lesion represents a thickening of the stratum corneum that becomes pigmented in a racially dependent manner. As well insulin as IGF-I receptors have been identified in cultured human keratinocytes. High levels of insulin can activate both receptors ${ }^{25}$. Additionally, TNF- $\alpha$ and IFN $\gamma$ cytokines that are often elevated in obesity, can induce up-regulation of PPAR $\beta / \delta$ and thereby keratinocyte proliferation 26,27 . Other skin problems associated with obesity are striae, plantar hyperkeratosis, acrochordons, intertrigo, pseudoacanthosis nigricans, keratosis pilaris, lymphedema and bacterial infections. The presence of striae, pseudoacanthosis nigricans and bacterial infections may correlate with the degree of obesity 28 . Psoriasis has been recognized as a systemic disease, associated with metabolic syndrome, type II diabetes, hypertension, dyslipidemia and obesity ${ }^{29-34}$. Further evidence indicates that overweight is a risk factor for the onset of psoriasis and that the BMI is correlated to the PASI (Psoriasis Area Severity Index) ${ }^{28}$.

\section{Small for gestational age children}

Risk groups for the development of obesity, are SGA children and children suffering from growth hormone deficiency (GHD). The concept of the development of health and disease (DOHaD) of David Barker relates diseases of adulthood like obesity to fetal programming: "The nourishment a baby receives from its mother, and its ex- 
posure to infection after birth, determine its susceptibility to chronic disease in later life". Adequate and balanced protein, energy and micronutrient intake during pregnancy might be a protective factor for adult obesity. Thus, improving women's nutritional status prior to and during pregnancy can substantially reduce the risk of low birth weight. Children born with low birth weight appeared to have less lean body mass, lower BMI and greater fat mass in adults ${ }^{19}$.

In SGA children, poor nutritional conditions during gestation can modify metabolic systems to adapt to expectations of chronic under nutrition. These children are potentially poorly equipped to cope with energy-dense diets and are possibly programmed to store as much energy as possible, leading to later obesity, metabolic syndrome, disturbed regulation of normal puberty and early onset of cardiovascular disease ${ }^{35}$. A follow up of 5654 men born from 1911 to 1930 in England demonstrated that men with the lowest weights at birth had highest death rates from ischemic heart disease ${ }^{36}$.

Fetal growth restraint is associated with maternal-uterine factors such as primiparity, smoking, restrictions in the maternal diet, maternal insulin resistance, and gestational diabetes. Alternatively, if an insulin resistant state was manifested in utero, then diminished fetal growth with SGA might be anticipated, because insulin is a powerful prenatal growth hormone ${ }^{14}$.

Insulin plays a central role in fetal growth. During the first two years of life, especially during the first 12 months of life, SGA newborns are usually able to catch-up growth velocity above the 50 th percentile ${ }^{37}$. Not only does this trend improve the final height, but it has also been associated with changes in insulin sensitivity ${ }^{38,39}$. If a SGA child shows a growth pattern that transcends the normal trend, the risk to develop obesity is evident.

Also children with growth hormone deficiency (GHD) are at risk to develop obesity. GDH children appear to have a higher fat mass. In children who do not suffer from growth hormone deficiency, the growth in length compensates the increase in weight. In GDH children this compensation mechanism does not work. In GHD children it is shown that besides its positive effect on growth, rhGH influences metabolism too ${ }^{40,41}$. The basal metabolic rate increases visible as a change in body composition by an increase in fat-free mass (FFM) ${ }^{42,43}$.

Adults with GHD are characterized by disturbances in body composition, lipid metabolism, cardiovascular risk profile and bone mineral density. It is well-known that adult GHD usually is accompanied by an increase in fat accumulation. Growth hormone replacement in adult patients with GHD results in reduction of fat mass and abdominal fat mass in particular ${ }^{44}$. 


\section{Early detection of obesity and prevention}

Early detection and prevention of obesity in an at-risk population is of utmost importance. One has to identify children not only when they are already obese, but even more important are the children with the tendency of becoming obese. Multiple strategies to prevent obesity in children are available worldwide, but most of them are applied at the moment a child is already overweight. It is more important to detect the predisposition of becoming overweight at the moment a child still has a healthy weight. For that reason knowledge of the longitudinal growth of weight and height of a healthy reference population is important. This information is available from the Dutch longitudinal growth study of Gerver and de Bruin ${ }^{45}$. Out of the original data of children from birth until four years of age a prediction model is constructed which gives the opportunity to calculate from each age onwards the expected height, weight and weight for height some years ahead. If the actual growth pattern of an individual child does not fit into the expected growth pattern, intervention may be needed to prevent obesity later on and thereby reduce the risk of the metabolic syndrome. Additionally, the question arises whether the study data of the reference population are conform the actual population or if there might be a change in height and weight due to a secular trend. It is of great interest to know at what age during infancy this secular trend in weight and height begins and if this trend can also be seen during intrauterine growth.

As mentioned above in SGA children it is evident that the increased risk on the metabolic syndrome is already present at birth. According to international guidelines a subgroup of the SGA children is treated with human growth hormone from the age of 4 years onwards. Besides an increase in height they also show a change in their metabolism resulting in a shift towards less fat mass and more fat-free mass. It is assumed that this shift is important to prevent the metabolic syndrome. The question arises if there is common basis for the development of the metabolic syndrome between the two groups of children, obese and SGA. Insulin resistance may play a role in the underlying pathogenesis.

\section{Outline of the thesis}

In the first chapter, an overview is given of the question about growth, obesity and the metabolic syndrome.

In the second chapter, we investigate whether the increase in weight is related to a secular trend in height. Furthermore, it is discussed whether the increase in weight is part of the increase in height or goes beyond this. A second aim was to examine whether this secular trend in height and weight is already visible during intrauter- 
ine growth. For this purpose we explored and compared growth data of prenatal growth studies. We also examined the relation between height and weight by the Body Mass Index (BMI) during the postnatal secular trend by comparing growth data of different postnatal growth studies.

In the third chapter, we explore whether short term changes in body composition, measured by total body water (TBW), as a result of rhGH therapy could be used to predict its growth effect after one year in children with GHD and SGA children. Because not all these children seem to benefit from this treatment it is important to predict whether a child will have an adequate or inadequate response to rhGH. This prediction is also important as a tool to predict a declining risk on the metabolic syndrome.

In the fourth chapter, we analyze the metabolic growth pattern, expressed as BMI and weight for height values of SGA children, treated with rhGH. The objective of this study was to investigate whether short-term changes in BMI and weight for height, as a result of rhGH could be used to predict its growth effect after one year in GHD- and SGA children. If the outcome is the same as by the Deuterium measurement of TBW, the result can be utilized as a tool in the daily practice of the Youth Health Care.

In the fifth chapter, we describe the construction of a prediction model for the development of obesity in children. This model is based on the longitudinal data of healthy infants, followed from birth until the age of 4 years. Most prevention programs are applicable from the age of approximately two years. Thereby most children are presented to the pediatrician at the moment their weight is already outside the normal range. Accordingly, we created a prediction model to detect the tendency of becoming overweight in childhood at a moment overweight has not been established. This model can be used in early childhood, in the first years of life. Such a model can provide the possibility to detect, whether the growth of an individual child still fits within the expected range of the growth velocity and thereby to detect if a child is at risk for an abnormal growth. Obesity prevention might then be possible already during the first years of life in the regular preventive health care program, coordinated by the Youth Health Care. Screening tools for deviated growth and body proportions are essential in a preventive program and can be used in the follow up of children.

In the sixth chapter, we applied the prediction model to an overweight and nonoverweight group to test our hypothesis. We compared our prediction model with 2 other methods to estimate (ab)normal growth of children: the often used weight for length growth chart and the BMI calculation. The prediction model can easily be used in the regular monitoring of children by the youth health care providers and thereby may reduce the incidence of obesity in childhood and thereby its comorbid- 
ities and health care costs. Especially in children overweight has to be prevented, because overweight and its co-morbidities will be one of the biggest health- and social care problems and costs in the future.

In the seventh chapter, the results are put into perspective. We discussed the position of our results within the existing knowledge about the prevention of obesity in childhood. 


\section{References}

1. Leger J, Garel C, et al. Human growth hormone treatment of short-stature children born for gestational age: effect on muscle and adipose tissue mass during a 3-year treatment period and after 1 year's withdrawal. J Clin Endocrinol Metab 1998; 83:3512-3516.

2. Ogden CL, Carroll MD, et al. Prevalence of obesity and trends in body mass index among US children and adolescents, 1999-2010. Journal of the American Medical Association 2012; 307(5):483-490.

3. National Center for Health Statistics. Health, United States, 2011: With Special Features on Socioeconomic Status and Health. Hyattsville, MD; U.S. Department of Health and Human Services; 2012.

4. Gupta N, Goel K et al. Childhood obesity in developing countries: Epidemiology, Determinants and Prevention. Endocrine Reviews 2012; 33(1):48-70.

5. Fredriks AM. Growth Diagrams, Fourth Dutch Nation-wide Survey 1997; 2004.

6. Quetelet A. l'Homme et le développement de ses facultés, Paris; 1835.

7. Westerterp KR, Wouters L, et al. The Maastricht protocol for the measurement of body composition and energy expenditure with labeled water. Obes Res 1995; 3:49-57.

8. Roth CL, Reinehr T. Roles of gastrointestinal and adipose tissue peptides in childhood obesity and changes after weight loss due to lifestyle intervention. Arch Pediatr Adolesc Med. 2010; 164:131138.

9. Witek J, Witek P, et al. Insulin resitance in children. Pediatr Endocrinol Diabetes Metab 2011; 17(4):206-13.

10. Sundaran SS, Zeitler $\mathrm{P}$, et al. The metabolic syndrome and nonalcoholic fatty liver disease in children. Curr Opin Pediatr 2009; 21(4):529-35.

11. Lee YS. Consequences of childhood obesity. Annals academy of Medicine Singapore 2009; 38:75-81.

12. Griffiths LJ, Wolke D, et al. Obesity and bullying: Different effects on boys and girls. Arch Dis Child 2006; 91:121.

13. Vaidya V. Psychosocial aspects of obesity. Advances in Psychosomatic Medicine 2006; 27:73-85.

14. Latner JD, Schwartz MB. Weight Bias in a Child's World. In: Brownell K. D., Puhl R. M., Schwartz M. B., Rudd L., editors. Weight Bias: Nature, Consequences, and Remedies. London: The Guildford Press; 2005:54-67.

15. Brownell KD. The chronicling of obesity: growing awareness of its social, economic, and political contexts. Journal of Health Politics, Policy and Law 2005; 30:955-64.

16. Dietz WH. Health consequences of obesity in youth: Childhood predictors of adult disease. Pediatrics 1998; 101:518-525.

17. Hughes AR, Sherrif A et al. Timing of adiposity rebound and adiposity in adolencense. Pediatrics 2014; 134(5):1354-61.

18. Desai M, Beall M et al. Developmental origins of obesity: programmed adipogenesis. Curr Diab Rep 2013; 13:27-33.

19. Yang Z, Huffman SL. Nutrition in pregnancy and early childhood and associations with obesity in developing countries. Maternal and Child Nutrition 2013; 9 (Suppl. 1):105-119.

20. Balaban G, Silva GA. Protective effect of breastfeeding in childhood obesity. J Pediatr 2004; 80(1):716.

21. Farooqi S, O'Rahilly S. Genetics of obesity in humans. Endocrine Reviews 2006; 27 (7): 710-718.

22. Manco M, Dallapiccola B, Genetics of pediatric obesity Pediatrics 2012; 130(1):123-33.

23. Ten S, Maclaren N. Insulin Resistance Syndrome in Children. Journal of Clinical Endocrinology and Metabolism 2004; 89(6):2526-2539.

24. Zimmet P, Alberti G, Kaufman F, et al. International Diabetes Federation Task Force on Epidemiology and Prevention of Diabetes. The metabolic syndrome in children and adolescents. Lancet 2007; 369:2059-2061.

25. Mantzoros CS, Flier JS. Insulin resistance: the clinical spectrum. Adv Endocrinol Metab 1995; 6:193232.

26. Tan NS, Michalik L, et al. Critical roles of PPAR $\beta / \delta$ in keratinocyte response to inflammation. Genes Dev 2001; 15:3263-3277. 
27. Michalik L, Desvergne B, et al. Impaired skin wound healing in peroxisome proliferator-activated receptor (PPAR) $\alpha$ and PPAR $\beta$ mutant mice. J Cell Biol 2001; 154:799-814.

28. Boza JC, Trindade EN, et al. Skin manifestations of obesity; a comparative study. J Eur Acad Dermatol Venereol 2012; 26(10):1220-1223.

29. Davidivici BB, Sattar N et al. Psoriasis and systemic inflammatory diseases: potential mechanistic links between skin disease and co-morbid conditions. J Invest Dermatol 2010; 130:1785-1796.

30. Kim N, Thrash B et al. Comorbidities in psoriasis patients. Semin Cutan Med Surg 2010; 29:10-15.

31. Hercogova J, Ricceri F et al. Psoriasis and body mass index. Dermatol Ther 2010; 23: 152-154.

32. Wolk K, Mallbris L et al. Excessive body weight and smoking associates with a high risk of onset of plaque psoriasis. Acta Derm Venereol 2009; 89:492-497.

33. Menter A, Griffiths CE et al. International Psoriasis Council. Exploring the association between cardiovascular and other disease-related risk factors in the psoriasis population: the need for increased understanding across the medical community. J Eur Acad Dermatol Venereol 2010; 24:1371-1377.

34. Prey S, Paul C et al. Cardiovascular risk factors in patients with plaque psoriasis: a systematic review of epidemiological studies. J Eur Acad Dermatol Venereol 2010; 24:23-30.

35. Roth CL, Sathyanarayana S. Mechanisms affecting neuroendocrine and epigenetic regulation of body weight and onset of puberty: potential implications in the child born small for gestational age (SGA) Rev Endoc Metab Disord 2012; 13(2):129-40.

36. Bradley TJ, Potts JE et al. Early changes in the biophysical properties of the aorta in pre-adolescent children born small for gestational age. J Pediatr. 2010; 156:388-92.

37. Boersma B, Wit JM. Catch-up growth. Endocr Rev. 1997; 18:646-61.

38. Bavdekar A, Yajnik CS et al. Insulin resistance syndrome in 8 year old Indian children: small at birth, big at 8 years, or both? Diabetes $1999 ; 48: 2422-9$.

39. Veening MA, Van Weissenbruch MM et al. Glucose tolerance, insulin sensitivity, and insulin secretion in children born small for gestational age. J Clin Endocrinol Metab. 2002; 87:4657-61.

40. Hassan HM, Kohno H, et al. Body composition, atherogenic risk factors and apolipoproteins following growth hormone treatment. Acta Paediatr 1996; 85:899-901.

41. Cowan FJ, Evas WD, et al. Metabolic effects of discontinuing growth hormone treatment. Arch Dis Child 1999; 80:517-523.

42. Gregory JW, Greene SA, et al. Changes in body composition and energy expenditure after six weeks' growth hormone treatment. Arch Dis Child 1991; 66:598-602.

43. Dempsher DP, Bier DM, et al. Whole body nitrogen kinetics and their relationship to growth in short children treated with recombinant human growth hormone. Pediatr Res 1990; 28:394-400.

44. Rasmussen MH, Obesity, growth hormone and weight loss, Mol Cell Endocrinol. 2010; 25 316(2):147-53.

45. Gerver WJM. de Bruin R. Paediatric Morphometrics, A reference manual. (second extended edition). University Press Maastricht, The Netherlands, ISBN 905278307 1; 2001. 



\section{CHAPTER 2}

OBESITY IN CHILDHOOD: A SECULAR TREND OR AN EPIDEMIC DISEASE?

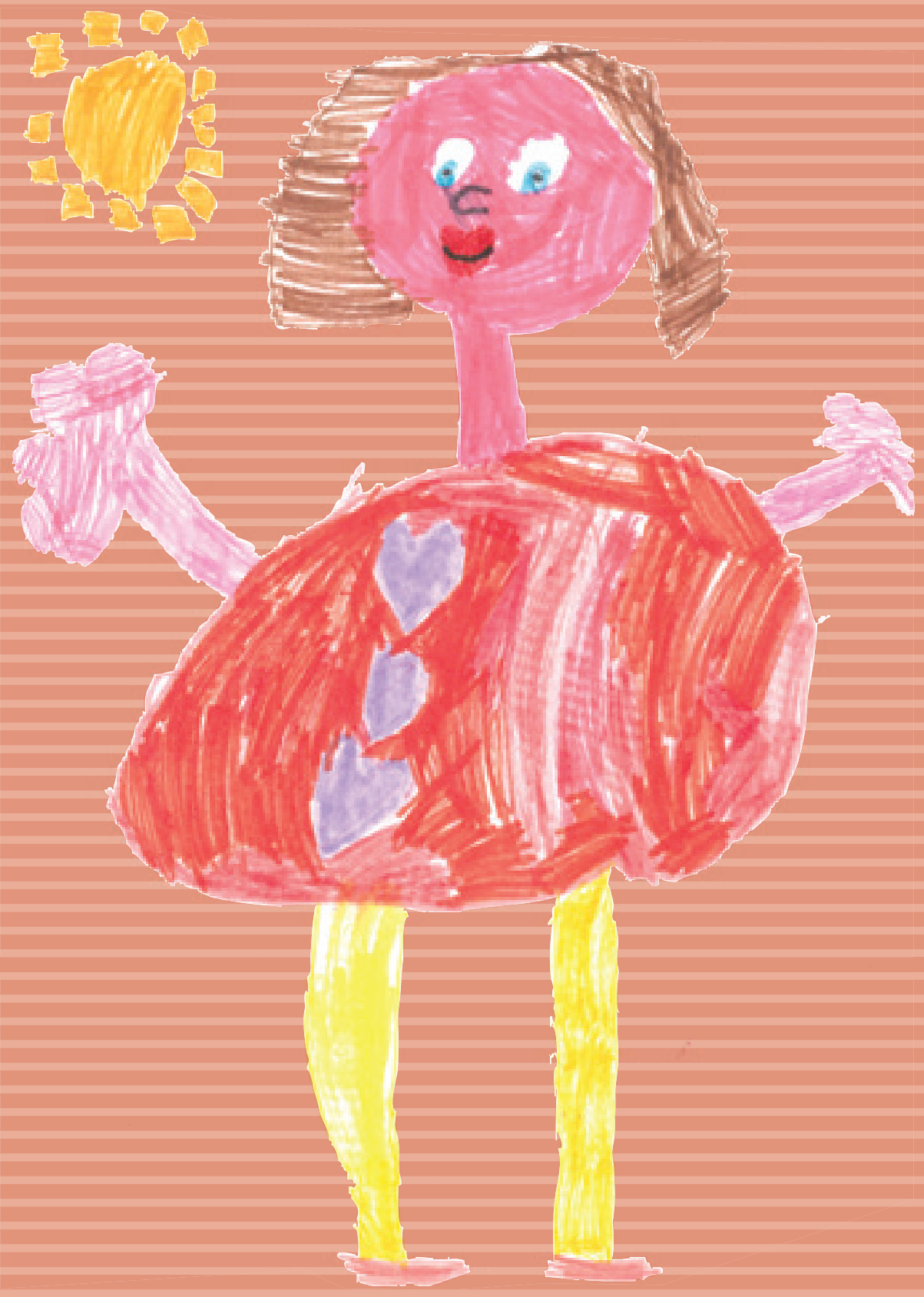


CHAPTER 2 


\section{CHAPTER 2 \\ Obesity in childhood: a secular trend or an epidemic disease?}

\footnotetext{
To achieve more insight into the origin of obesity, we studied the growth of children throughout the past decennia. The question arises, whether the trend to obesity already starts during the prenatal period and to what extent the increase of weight is related to a secular trend in height.

For neonatal data, three studies, performed in The Netherlands, with neonatal data of birth weights were compared. For postnatal data, weight, height and Body Mass Index (BMI) of two nationwide studies, performed in the Netherlands, were analyzed.

No differences between birth weights were found between 1970 and 2007. In postnatal data a trend of increasing weight and BMI in both boys and girls starts from five years onwards. The secular trend in height starts from the age of two and a half years onward in both boys and girls. The increase in weight is more pronounced than the increase in height.

No prenatal secular trend could be detected in The Netherlands. Postnatal, the secular trend is obvious for weight, height and BMI. The increase in skewness of the weight distribution may be ascribed to a metabolic disturbance of the population.
}

This chapter is published in:

Journal of Child Health Care Volume 17 Issue 1, March 2013

by Manon AB Ernst, Willem JM Gerver, Michelle YG Simons, Maria WJ Jansen, Mark AHBM van der Hoeven, Luc JI Zimmermann.

The article has also been selected as part of a special issue of the Journal of Child Health Care. The special issue reflects international perspectives with papers reporting on issues within the Netherlands, Germany, Norway, Australia, Canada, USA and the UK. 
CHAPTER 2 


\section{Introduction}

There is rising concern about the increasing incidence of overweight and obesity, not only in adults but also in children ${ }^{1}$. Obesity is one of the most serious present and possible future health problems, because of co-morbidities such as diabetes mellitus type II, cardiovascular diseases, joint problems and psychosocial problems. During the last 30 years, the prevalence of overweight and obesity in The Netherlands has increased ${ }^{2,3}$.

The question arises as to whether this increase in weight may be attributed to or aligned with a secular trend in height? A secular trend describes the change in physical development from one generation to the next and can be interpreted as a 'mirror of conditions in society', as Tanner stated ${ }^{4}$. The improved physical and psychological condition over the last 100 years in Western society, due to improved foods, living conditions and less diseases, led indeed to a tendency for children to become progressively larger and heavier at all ages. The aim of this study was to examine whether this secular trend in height and weight is already visible during intrauterine growth. Secondly, the rate between height and weight expressed by the Body Mass Index (BMI) as weight divided by squared height, during this secular trend was examined ${ }^{5}$. To compare growth data of children in the Netherlands concerning the prenatal growth and postnatal growth, we analyzed two data sets. Especially a secular trend in prenatal growth with respect to population of the Netherlands has not been investigated before.

\section{Methods}

\section{Prenatal growth curves}

All the available nationwide data for prenatal growth in the Netherlands were used, these include two sets of growth data: The Kloosterman study from $1970^{6}$ and the Perinatreg study from $2001^{7}$.The big time span between those studies can offer insight in a possible trend in growth. In the Kloosterman study, birth weight data of 80,000 infants were presented. All children were born at gestational age between 25 to 40 weeks in two Amsterdam clinics. The infants were subdivided by gender and those born from primiparae and multiparae ${ }^{6}$.

The Perinatreg study consisted of a nationwide birth weight registration of 176,093 infants of the gestational age between 25 to 40 weeks, gathered in 2001. The total group is subdivided in infants born from primigravida and multiparous women 7 .

To compare the two studies, the mean weight value for each gestational age in weeks of the Kloosterman registration was subtracted from the Perinatreg data. 
The neonatal data of the Maastricht University Medical Centre (MUMC) were added, because these data are collected in one specific region. The above-mentioned studies are from different regions: Amsterdam and the whole of The Netherlands. The azM registration between 1988 and 2007 is divided in two groups: the first of 1988 which consists of 679 newborns, the second of 2007 consisting of 1,109 newborns, all born at gestational age of 24-40 weeks. Unlike the other described studies, these data included length measurements. Therefore, the relation weight to length was evaluated as well. The oldest data from 1988 were compared to the recent ones from 2007.

\section{Postnatal growth curves}

With respect to the postnatal growth the nationwide growth studies, performed in The Netherlands, by van Wieringen and Fredriks were compared ${ }^{8,9}$. The van Wieringen study collected data from a nationwide survey of 55,000 children and adolescents between 1964 and 1966. The data pertained to height and weight of respondents being recorded at one weekly intervals until 52 weeks and at 26 weekly intervals thereafter?.

The nationwide study of Fredriks on weight and height was performed from 19961997: a total of 14,500 children, 7,482 boys and 7,018 girls, were included ${ }^{8}$. Until the age of one year, the measurements were presented in weekly intervals and after the age of one year in yearly intervals.

In our study we calculated the BMI, expressed as weight (in kilograms) divided by the squared height (in meters) from the given percentile values of the different studies. We compared the data of the study of van Wieringen (1972) with the more recent data of Fredriks (2004).

\section{Results}

\section{Prenatal growth studies}

Figure 1 shows the difference between the birth weight data of the neonatal registration from the Kloosterman study in 1970 and the data from the nationwide Perinatreg study in 2001. The maximal difference between the two studies is 187 grams for boys at gestational age of 29 weeks and 221 grams for girls at gestational age of 31 weeks. In the period before 34 weeks the more recent data show lower birth weights. Because these results were independent of the parity, the mean values of the data of primiparae and multiparae are not presented separately. 


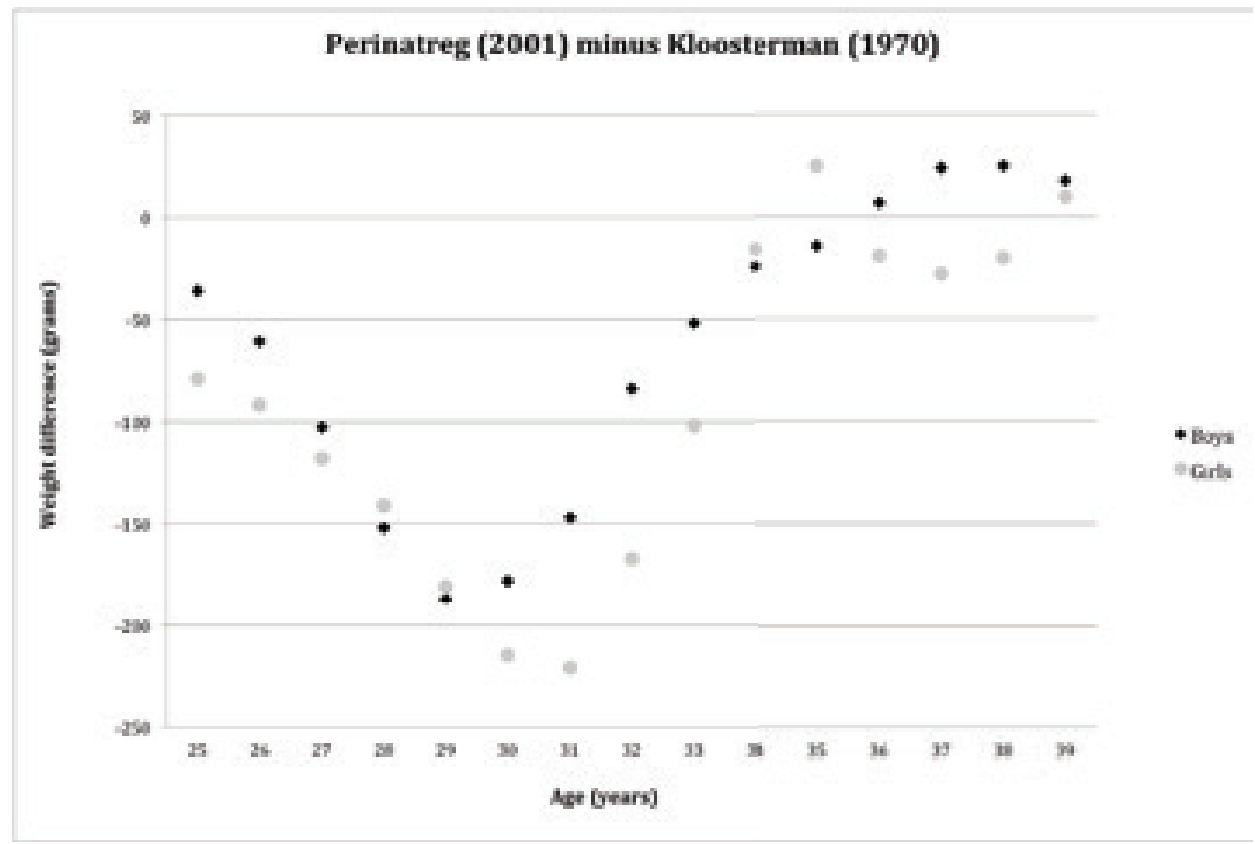

Figure 1: Weight difference for boys and girls between the Kloosterman study and the Perinatal registration.

For the Maastricht study the length and weight data of 1988 and 2007 showed no difference. Weight plotted against height also revealed no difference between the two study groups despite an interval of 20 years.

\section{Postnatal growth studies}

In Table 1 and Table 2 the differences for height and weight between the studies of van Wieringen and Fredriks are presented for girls and boys. The mean data for height show that in the more recent study (Fredriks) both boys and girls were shorter from birth onwards until the age of approximately two years. The maximum difference in this time period between both studies is $-0.9 \mathrm{~cm}$ for girls and $0.7 \mathrm{~cm}$ for boys. At the age of two and a half years and further the height in the more recent study is increased with a maximal difference between both studies of $4.3 \mathrm{~cm}$ in girls and $3.4 \mathrm{~cm}$ in boys at the age of ten years.

For weight a similar pattern is seen (Table 1). Until the age of four years the children from the more recent study of Fredriks had a lower mean weight compared to the children from the study of van Wieringen. After the age of four to five years there is a turning point. The children from the more recent study have a higher weight and this difference is increasing with the age. The differences in height and weight between the two studies are given for 3 percentiles $\left(\mathrm{P}_{3}, \mathrm{P}_{50}\right.$ and $\left.\mathrm{P}_{97}\right)$. These 
percentiles give an indication of the percentage of the concerning population that is below a certain value. For example, a $\mathrm{P}_{3}$ value for height of $92 \mathrm{~cm}$ means that $3 \%$ of the concerning population has a length below $92 \mathrm{~cm}$. The $\mathrm{P}_{50}$ value is the median; $50 \%$ of the concerning population has a length below and $50 \%$ a length above this value. At the $\mathrm{P}_{3}$ the difference in weight starts at 108 grams ending up with a difference of 1071 grams for girls. At the $\mathrm{P}_{50}$ the difference in weight starts at the age of five years, with a difference of 300 grams ending up at the age of ten years with a difference of 3200 grams. In boys the difference mean weight also starts at the age of five years beginning with 400 grams and ending up at the age of ten years with 2400 grams. At the $\mathrm{P}_{97}$ curve the deviation starts at the age of four years with 797 grams to a maximum difference of 7447 grams at ten years for girls.

Table 1: Differences in weight and height of girls until the age of ten years between the study of Fredriks (1996-1997) and van Wieringen (1964-1966).

\begin{tabular}{|c|c|c|c|c|c|c|}
\hline \multirow[b]{2}{*}{ Age (y) } & \multicolumn{3}{|c|}{ height $(\mathrm{cm})$} & \multicolumn{3}{|c|}{ weight (gr) } \\
\hline & $\mathrm{P}_{3}$ & $\mathrm{P}_{50}$ & $\mathrm{P}_{97}$ & $\mathrm{P}_{3}$ & $\mathrm{P}_{50}$ & $\mathrm{P}_{97}$ \\
\hline 0.27 & -0.5 & -0.9 & -0.7 & 115 & -10 & -23 \\
\hline 0.31 & -0.5 & -0.9 & -0.8 & 41 & -30 & 11 \\
\hline 0.38 & -0.6 & -0.8 & -0.6 & 27 & -20 & 35 \\
\hline 0.46 & -0.6 & -0.8 & -0.8 & -47 & -70 & -1 \\
\hline 0.54 & -0.7 & -0.8 & -0.7 & -159 & 20 & 9 \\
\hline 0.62 & -0.7 & -0.8 & -0.8 & -155 & -150 & -63 \\
\hline 0.69 & -0.9 & -0.8 & -0.7 & -205 & -280 & -179 \\
\hline 0.77 & -0.9 & -0.8 & -0.8 & -199 & -280 & -165 \\
\hline 0.85 & -0.9 & -0.7 & -0.5 & -233 & -330 & -201 \\
\hline 0.92 & -0.8 & -0.6 & -0.5 & -267 & -350 & -281 \\
\hline 1 & -0.7 & -0.5 & -0.5 & -193 & -450 & -243 \\
\hline 2 & 0.1 & -0.2 & -1.0 & -257 & -500 & -590 \\
\hline 3 & 0.1 & 0.2 & 0.0 & -22 & -200 & -38 \\
\hline 4 & 0.0 & 0.3 & 0.5 & 108 & 0 & 797 \\
\hline 5 & 0.8 & 0.9 & 1.1 & 150 & 300 & 1425 \\
\hline 6 & 1.5 & 1.4 & 1.5 & 498 & 1000 & 2536 \\
\hline 7 & 1.7 & 1.9 & 2.3 & 751 & 1500 & 3817 \\
\hline 8 & 2.2 & 2.5 & 2.7 & 817 & 2000 & 5268 \\
\hline 9 & 2.8 & 3.3 & 3.7 & 888 & 2500 & 6508 \\
\hline 10 & 3.3 & 4.3 & 3.8 & 1071 & 3200 & 7447 \\
\hline
\end{tabular}


Table 2: Differences in weight and height of boys until the age of ten years between the study of Fredriks (1996-1997) and van Wieringen (1964-1966).

\begin{tabular}{|c|c|c|c|c|c|c|}
\hline \multirow[b]{2}{*}{ Age (y) } & \multicolumn{3}{|c|}{ height $(\mathrm{cm})$} & \multicolumn{3}{|c|}{ weight (gr) } \\
\hline & $\mathrm{P}_{3}$ & $\mathrm{P}_{50}$ & $\mathrm{P}_{97}$ & $\mathrm{P}_{3}$ & $\mathrm{P}_{50}$ & $\mathrm{P}_{97}$ \\
\hline 0.27 & -0.5 & -0.5 & -0.3 & 197 & 220 & 141 \\
\hline 0.31 & -0.5 & -0.5 & -0.4 & 103 & 180 & 175 \\
\hline 0.38 & -0.6 & -0.6 & -0.5 & 39 & 120 & 169 \\
\hline 0.46 & -0.7 & -0.6 & -0.3 & -65 & 20 & 217 \\
\hline 0.54 & -0.6 & -0.5 & -0.3 & -99 & 0 & 251 \\
\hline 0.62 & -0.7 & -0.5 & -0.1 & -89 & -60 & 235 \\
\hline 0.69 & -0.7 & -0.7 & -0.3 & -163 & -100 & 249 \\
\hline 0.77 & -0.7 & -0.7 & -0.3 & -227 & -120 & 273 \\
\hline 0.85 & -0.7 & -0.6 & -0.1 & -341 & -210 & 237 \\
\hline 0.92 & -0.6 & -0.5 & -0.1 & -301 & -260 & 231 \\
\hline 1 & -0.6 & -0.4 & 0.1 & -345 & -300 & 225 \\
\hline 2 & 0.0 & 0.0 & -0.5 & -145 & -300 & -202 \\
\hline 3 & 1.5 & 0.6 & -0.7 & -216 & -400 & 56 \\
\hline 4 & 1.2 & 0.8 & 0.3 & -186 & -200 & 703 \\
\hline 5 & 1.8 & 1.7 & 1.3 & 56 & 400 & 1737 \\
\hline 6 & 2.5 & 2.3 & 2.2 & 598 & 1200 & 2960 \\
\hline 7 & 2.8 & 2.8 & 2.9 & 939 & 1400 & 3465 \\
\hline 8 & 3.1 & 3.2 & 3.4 & 999 & 1700 & 3963 \\
\hline 9 & 2.7 & 3.5 & 4.2 & 1152 & 2000 & 4744 \\
\hline 10 & 2.2 & 3.4 & 4.6 & 1112 & 2400 & 5519 \\
\hline
\end{tabular}

Figure 2 shows the average difference in BMI for boys and girls between the children of the van Wieringen group and those of the Fredriks group. Between the age of one year and five years, the boys and girls of the Fredriks group have a lower BMI compared to those of the van Wieringen group. After the age of five years the data of the recent study show a higher BMI compared to the data from van Wieringen. 


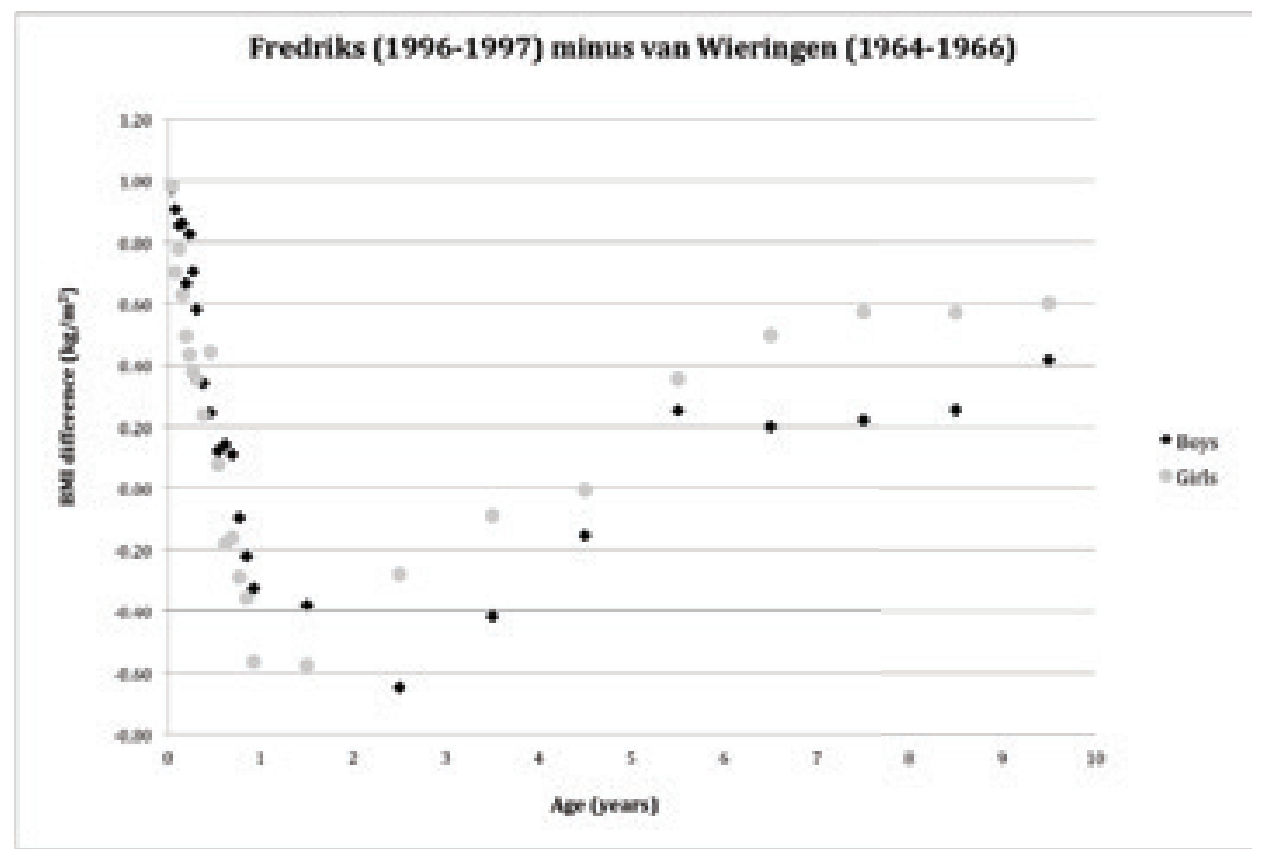

Figure 2: BMI difference for boys and girls between the van Wieringen study and the Fredriks study.

In Figure 3 and 4 the relation weight for height from birth until the age of ten years for girls and boys is shown, as taken from the $\mathrm{P}_{3}, \mathrm{P}_{50}$ and $\mathrm{P}_{97}$ values from the studies by van Wieringen and Fredriks. At the $\mathrm{P}_{3}$ there is hardly any difference shown between both studies. The curves at the $97^{\text {th }}$ percentile on the other hand show an obvious deviation by increasing height. The children of the more recent study of Fredriks show a trend in which they have a higher weight for height compared to the data of van Wieringen. The deviation becomes visible at a height of approximately $113 \mathrm{~cm}$ in both boys and girls. 
OBESITY IN CHILDHOOD: SECULAR TREND OR EPIDEMIC DISEASE?

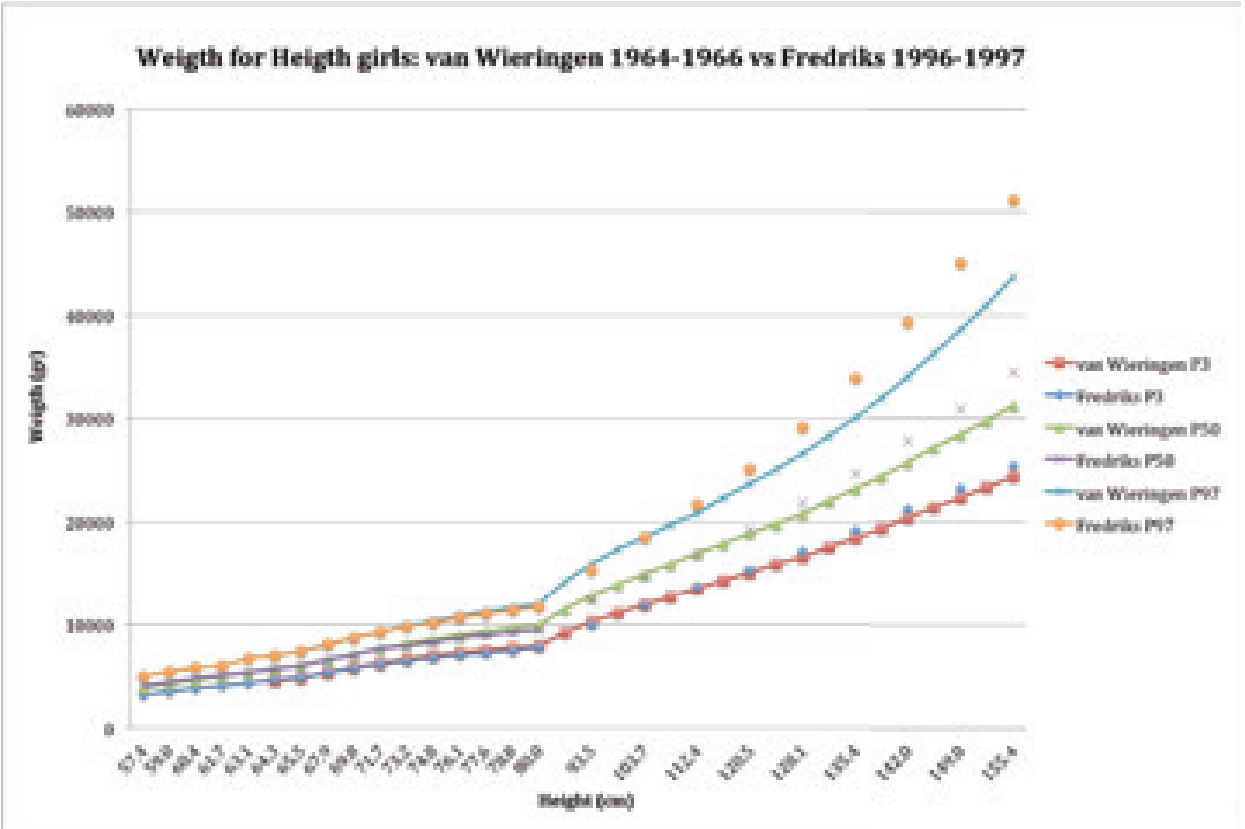

Figure 3: Weight versus height from $\mathrm{P}_{3}, \mathrm{P}_{50}$ and $\mathrm{P}_{97}$ values for girls of the van Wieringen study and the Fredriks study.

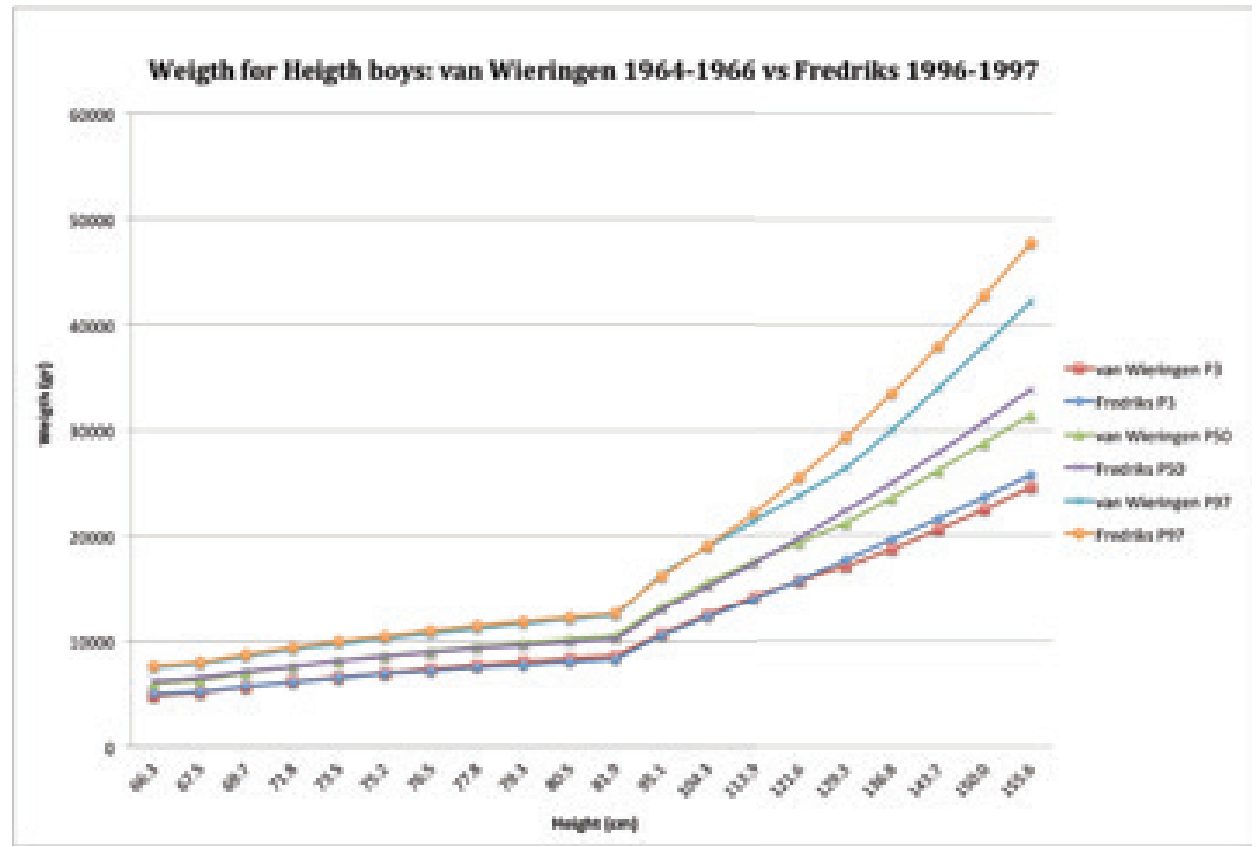

Figure 4: Weight versus height from $\mathrm{P}_{3}, \mathrm{P}_{50}$ and $\mathrm{P}_{97}$ values for boys of the van Wieringen study and the Fredriks study. 
Table 3 gives the differences of weight, height and BMI between the data of van Wieringen and the data of Fredriks for boys and girls at the age of ten years. The differences are calculated for the $\mathrm{P}_{3}, \mathrm{P}_{50}$ and $\mathrm{P}_{97}$. The differences are presented as percentage of the original $\mathrm{P}_{3}, \mathrm{P}_{50}$ and $\mathrm{P}_{97}$ values of van Wieringen. As an example, in boys the mean height at the $\mathrm{P}_{50}$ of the Fredriks population increased with $3.4 \mathrm{~cm}$ which is equivalent to an increase of $2.40 \%$. In addition the weight at the same percentile increased with an average of $2.4 \mathrm{~kg}$. This is equivalent to an increase of $7.60 \%$. The corresponding increase of the BMI of $0.4 \mathrm{~kg} / \mathrm{m}^{2}$ is $2.55 \%$.

Table 3: Differences of weight, height and $\mathrm{BMI}$ at $\mathrm{P}_{3}, \mathrm{P}_{50}$ and $\mathrm{P}_{97}$ between the data of van Wieringen and Fredriks for boys and girls.

\begin{tabular}{lllllll}
\hline \multicolumn{7}{l}{ Fredriks (1996-1997) - van Wieringen (1964-1966) } \\
& $\mathrm{P}_{3}$ & \multicolumn{5}{l}{} \\
\hline Height $_{\text {boys }}$ & $+2.2 \mathrm{~cm}$ & $1.70 \%$ & $+3.4 \mathrm{~cm}$ & $2.40 \%$ & $+4.6 \mathrm{~cm}$ & $3 \%$ \\
Height $_{\text {girls }}$ & $+3.3 \mathrm{~cm}$ & $2.97 \%$ & $+4.3 \mathrm{~cm}$ & $3.09 \%$ & $+3.8 \mathrm{~cm}$ & $2.50 \%$ \\
Weight $_{\text {boys }}$ & $+1.1 \mathrm{~kg}$ & $0.45 \%$ & $+2.4 \mathrm{~kg}$ & $7.60 \%$ & $+5.5 \mathrm{~kg}$ & $13 \%$ \\
Weight $_{\text {girls }}$ & $+1.07 \mathrm{~kg}$ & $4.40 \%$ & $+3.2 \mathrm{~kg}$ & $10.20 \%$ & $+7.4 \mathrm{~kg}$ & $17 \%$ \\
BMI $_{\text {boys }}$ & +0.12 & $0.80 \%$ & +0.4 & $2.55 \%$ & +1.2 & $6.50 \%$ \\
BMI $_{\text {girls }}$ & -0.15 & $-1 \%$ & +0.6 & $3.70 \%$ & +2.2 & $11.50 \%$ \\
\hline
\end{tabular}

\section{Discussion}

The increase in weight in children is obvious. Therefore, we examined whether this phenomenon is actually related to the secular trend in height and thereby also in weight, or a phenomenon beyond the expected increase fitting the height. We first examined whether a secular trend already exists during intrauterine growth. To answer these questions, we compared different growth studies, performed in The Netherlands, within a time span of several decades.

\section{Prenatal growth studies}

Comparison of the neonatal curves unexpectedly revealed a lower birth weight in the more recent data in boys born between 26 and 33 weeks and in girls between 25 and 33 weeks. The observed weight difference could be explained by the fact that gynaecologists currently do accept or induce delivery at an earlier gestational age in case of a threatened and/or growth retarded infant. At the time of the Kloosterman study, there was no intervention in such an early stage of pregnancy lacking the modern postnatal medical support. In general, it must be remarked that reference intrauterine growth curves are based on measurements of premature born infants with possibly an abnormal intrauterine growth pattern. Children born at 34 to 39 weeks onwards, no difference in weight is visible, in both boys and girls between 1970 and 2001. Therefore a secular trend in prenatal growth in this time 
span can be excluded. We conclude that the process of a secular trend is only expressed after birth. The assumption can be made that the intrauterine environment and the placental nutrition supply prevent the fetus from becoming overgrown.

The two above-mentioned populations not only differ in time span but also in their socioeconomic background. The Kloosterman population concerned the low socioeconomic classes of Amsterdam ${ }^{6}$ in contrast to the Perinatreg study, which is nationwide and includes all socioeconomic classes in the Netherlands ${ }^{7}$. For that reason we compared two populations with the same socioeconomic background in the more homogeneous MUMC population. Besides, in this study group also length values were available so we could compare weight in relation to length. No difference was found between the measurements of weight and length neither in the interrelation between these two measurements, measured at birth in 1988 and 2007. Therefore, it is assumed that the socioeconomic differences between the two populations of Kloosterman and Perinatreg do not affect the results.

\section{Postnatal growth studies}

To evaluate a postnatal secular trend in weight and height, the growth curves from the studies by van Wieringen and Fredriks were compared ${ }^{8,9}$.

Both height and weight were higher during the first years of life in the older study. An explanation could be that food composition for infants changed during the past 30 years $^{10}$. The energy intake of the population of 1964 during the first three years of life exceeded the energy intake of the population of 1996 due to differences in feeding habits, while the energy expenditure is probably equal at this age. After the age of five years the energy expenditure is apparently decreased during the past 30 years. An explanation could be that energy expenditure is decreasing in childhood, for example because of lack of movement due to watching television or playing computer games.

By analyzing the BMI, there is a remarkable increase of the BMI visible from the age of approximately five years. However, it has to be realized that the increase of the BMI is highly dependent on the increase of height*. As an example a ten years old boy is presented (Table 4) in which the BMI is calculated by the measures of height at a given percentile with corresponding weight. As is illustrated in Table 4, at the same age, the BMI varies widely depending on the height*. 
Table 4: height, weight and corresponding BMI values of the $3^{\text {rd }}, 50^{\text {th }}$ and $97^{\text {th }}$ percentile of a 10 -year old boy.

\begin{tabular}{llll}
\hline Boy, 10 years & Height $(\mathrm{cm})$ & Ideal Weight $(\mathrm{kg})$ & BMI $\left(\mathrm{kg} / \mathrm{m}^{2}\right)$ \\
\hline $\mathrm{P}_{3}$ & 129 & 24.7 & 14.84 \\
$\mathrm{P}_{50}$ & 141 & 30 & 15.09 \\
$\mathrm{P}_{97}$ & 152 & 37.5 & 16.32 \\
\hline
\end{tabular}

Although the BMI is the usual ratio to express weight for height related to age, weight plotted against height independent of age is a more reliable comparison in children*. In the Figures 3 and 4 it is seen that there is an increase in weight for height comparing the recent data of Fredriks with the older data of van Wieringen. Although there is a secular trend visible for height, the increasing weight goes beyond this secular trend, especially for the $\mathrm{P}_{97}$ values resulting in a skewed distribution. This is even more pronounced realizing that in the latest growth study, performed in The Netherlands, the secular trend in height has stopped at all. Since 1955 there in an increase in height, but between 1997 and 2010 this increase discontinued as visible in Table 5 . The trend in weight did not stop, according to this study ${ }^{11}$.

Table 5: Final height of boys and girls from 1955-2010.

\begin{tabular}{llllll}
\hline & 1955 & 1965 & 1980 & 1997 & 2010 \\
\hline Boys & $176.0 \mathrm{~cm}$ & $178.0 \mathrm{~cm}$ & $182.0 \mathrm{~cm}$ & $184.0 \mathrm{~cm}$ & $183.8 \mathrm{~cm}$ \\
Girls & $163.0 \mathrm{~cm}$ & $166.3 \mathrm{~cm}$ & $168.3 \mathrm{~cm}$ & $170.6 \mathrm{~cm}$ & $170.7 \mathrm{~cm}$ \\
\hline
\end{tabular}

As is illustrated in the examples of Table 4, the BMI also shows a skewed distribution, in contrast to the original BMI data of Quetelet ${ }^{5}$. Both data sets are based on prepubertal data. The normal distribution as found by Quetelet has changed in a skewed distribution nowadays. Realizing that the BMI is defined as weight divided by the squared height, the secular trend must be more pronounced for weight than for height.

\section{Conclusion}

During the last decennia there is no secular trend of height and weight visible during the intrauterine period, in contrast to the postnatal growth curves. However, the phenomenon of increasing BMI can be partly explained by the increase in height*. Evidently the increase in skewness of the weight distribution must be ascribed to a metabolic disturbance of the population.

According to these data, it is of great importance to take the described trends in weight and height in children into account in general practice. The increase in 
weight and BMI is obvious, but the increase in height stopped recently. If height increases, BMI also increases*. Taking into account the information that height does not increase anymore, the increase in BMI means a higher increase in weight. The BMI may be misleading in interpreting growth of children*.

Another limitation of the anthropometric approach of overweight is that the BMI as well as weight for height does not distinct between fat mass (FM) and fat-free mass (FFM) ${ }^{12}$. In adipose children it is reasonable to ascribe the weight gain to an increase in FM, but at the same time in relatively lean children a lower weight is largely due to a shift from FM to FFM ${ }^{12}$. Therefore Fredriks stated that waist circumference could be used as a better tool to screen for increased abdominal fat in children ${ }^{13}$.

It is of great importance to detect and treat children who are already overweight at an early age. Prevention at an early age is necessary in reducing the problem of obesity or malnutrition and its co-morbidities, which will be a threat for the population in the future.

* It is true that the increase of BMI partly can be explained by the increase in height, taking the P3, P50 and P97 values into account, but only below the age of about 10 years. During that period the increase in weight is less pronounced than the increase in height: on the curve weight for height the linear regression is $y=0.283 \mathrm{x}$ 12.26. Beyond the age of ten years, the increase in weight compared to weight is more pronounced: $y=0.753 x-74.87$. 


\section{References}

1. Cole TJ, Bellizzi MC, et al. Establishing a standard definition for child overweight and obesity worldwide: international survey. British Medical Journal 2000; 320(7244):1240-1243.

2. Hurk van den K, Dommelen van P, et al. Prevalentie van overgewicht en obesitas bij jeugdigen 4-15 jaar in de periode 2002-2004. TNO Leiden; 2004.

3. Fredriks AM, Buuren van S, et al. Alarming prevalences of overweight and obesity for children of Turkish, Moroccan and Dutch origin in The Netherlands according to international standards. Acta Paediatrica 2005; 94(4):496-498.

4. Tanner JM. Growth as a mirror of conditions in society. In: Lindgren GW (ed.) Growth as a mirror of conditions in society. Institute of Education Press, Stockholm 1990:9-48.

5. Quetelet A. l'Homme et le développement de ses facultés. Bachelier, imprimeur-libraire, quai des Augustins, no 55. Paris; 1835.

6. Kloosterman GJ. On intrauterine growth, the significance of prenatal care. International Journal of Gynaecology \& Obstetrics 1970; 8(6):895-912.

7. Stichting Perinatale Registratie Nederland. Perinatale zorg in Nederland 2006. Stichting Perinatale Registratie Nederland. Zutphen; 2008.

8. Fredriks AM. Growth Diagrams: Fourth Dutch Nation-wide Survey 1997. Leiden; 2004.

9. Wieringen van JC. Seculaire groeiverschuiving, lengte en gewicht surveys 1964-1966 in Nederland in historisch perspectief. Netherlands Institute for Preventive Medicine: TNO Leiden; 1972.

10. Jonxis JHP. De voeding van de jonge zuigeling. Nederlands Tijdschrift voor Geneeskunde 1974; 118: nr 20.

11. Schonbeck Y, Buuren van S. Vijfde Landelijke Groeistudie. Leiden 2010:TNO.

12. Freedman S, Sherry B. The validity of BMI as an indicator of body fatness and risk among children. Pediatrics 2009; 124:S23-S24.

13. Fredriks AM, van Buuren S, et al. Are age references for waist circumference, hip circumference and waist-hip ration in Dutch children useful in clinical practice? European Journal of Pediatrics 2005; 164(4):216-222. 
OBESITY IN CHILDHOOD: SECULAR TREND OR EPIDEMIC DISEASE? 



\section{CHAPTER 3}

CHANGE IN TOTAL BODY WATER AS

A PREDICTIVE TOOL FOR GROWTH HORMONE TREATMENT RESPONSE

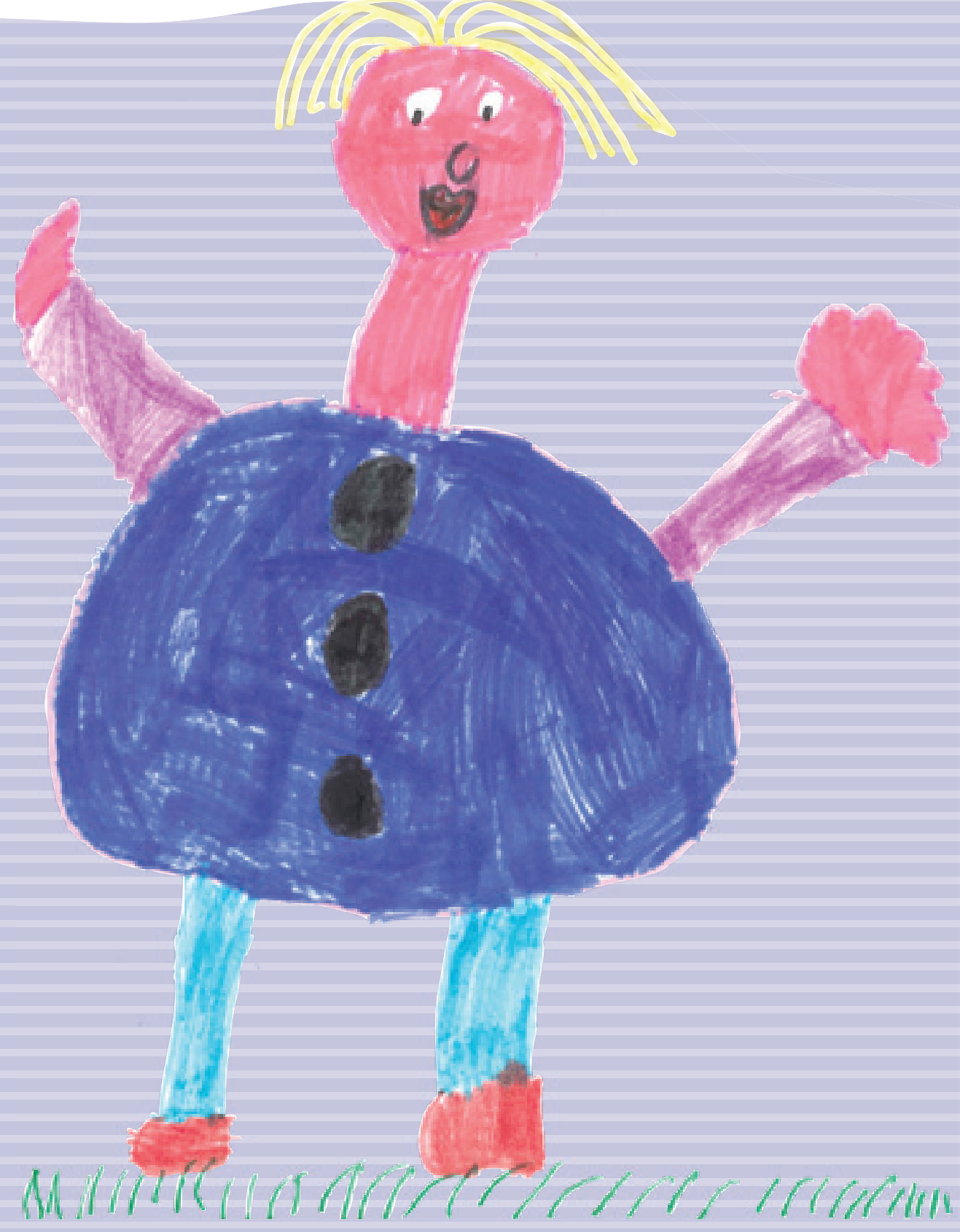


CHAPTER 3 


\section{CHAPTER 3}

\section{Change in total body water as a predictive tool for growth hormone treatment response}

This chapter is published in:

Hormone Research in Paediatrics, 2012;78:18-23

by: Manon AB Ernst, Michelle YG Simons, Angèle JGM Gerver, Gladys RJ Zandwijken, Luc JI Zimmermann, Willem JM Gerver. 


\section{Abstract}

To investigate whether short term changes in body composition as a result of growth hormone therapy could be used to predict its growth effect after one year in children with growth hormone deficiency (GHD) and children born small for gestational age (SGA).

88 GHD children and 99 SGA children who started treatment with recombinant human growth hormone (rhGH) were included. Total body water (TBW) and height were measured. After one year patients were divided into adequate and inadequate responders.

In GHD and SGA children a sensitivity of $87 \%$ and $53 \%$ resp. and a specificity of $58 \%$ and $83 \%$ resp. was found. The positive predictive values for GHD and SGA children are $73 \%$ and $90 \%$ resp. The negative predictive values are $75 \%$ and $32 \%$ resp.

In conclusion: Changes in body composition data measured by TBW are a valuable tool to correctly predict $75 \%$ of the GHD children and are only useful in SGA children when the change in TBW is above the cut off value of $0.7 \mathrm{l} / \mathrm{m}^{2}$. 


\section{Introduction}

In pediatric endocrinology short stature is a frequently seen problem. Children with short stature due to growth hormone deficiency (GHD) or due to be born small for gestational age (SGA) are indicated for growth hormone treatment. However, not all children seem to benefit from this treatment and it is unclear how to predict whether a child will have an adequate or inadequate response to growth hormone therapy.

Short stature as a result of GHD has an incidence of 1:3500 and is the original indication for treatment with recombinant human growth hormone (rhGH) in childhood. According to the Dutch rules at least two stimulation tests (for example clonidine and arginine test) with an increase of growth hormone below $20 \mathrm{mU} / \mathrm{l}$ are needed to confirm the diagnosis of GHD and to obtain an indication for rhGH treatment $^{1}$. Despite the results of the stimulation tests, the individual responses to treatment with rhGH vary widely. The second well-defined indication for rhGH treatment ${ }^{2}$ is restricted to those infants with birth weight and/or length of at least 2 SD below the mean for gestational age, and without catch-up growth before the age of 4 years $(\mathrm{SGA})^{1}$. They do not need a stimulation test and a normal value of insuline-like growth factor (IGF1) is no contraindication for treatment. Most of the SGA children have a spontaneous catch-up growth in the first 2 years of life, but 1 out of 10 subjects remains of short stature during childhood and seems to benefit from treatment with rhGH. The mechanisms that are involved in this catch-up growth in SGA children are unknown ${ }^{2}$ and none of the endocrine parameters seem to have any predictive value.

Already at an early age both the GHD and the SGA children show abnormalities in body composition ${ }^{3}$. While GHD children show an increased total body fat, SGA children show a reduced body fat percentage ${ }^{4,5}$. Treatment with rhGH in adults causes a shift in body composition towards an increase in fat-free mass (FFM) ${ }^{6}$. In children with GHD the same effect was found in several studies during treatment with $\mathrm{rhGH}^{3,7-11}$. It is also proven that a shift in body composition is already present after 6 weeks of treatment ${ }^{8-12}$. In the study of Hoos et al. ${ }^{13}$ it is shown that the increase in FFM, measured with the Deuterium dilution method after 6 weeks of treatment, is a valuable tool for distinction between good and poor responders on growth measured after one year of treatment in children diagnosed with GHD. A comparable effect in SGA children is not described in literature yet.

\section{Objectives}

Based on the above mentioned results a Dutch nationwide study was performed to investigate whether the findings of the study of Hoos et al. ${ }^{13}$ could be confirmed in a larger cohort of children indicated for rhGH treatment. A second objective of this 
study was to investigate if these metabolic effects could also be seen in SGA children treated with rhGH after 6 weeks and whether these effects are also a predictive tool for growth response after one year.

\section{Importance of the study}

Until now, height measurement during a period of one year of treatment with rhGH is recommended for a reliable evaluation of the growth response. Because the evaluation of the effect lasts such a long time, some children are unnecessarily treated with rhGH, consisting of daily injections. Besides, growth hormone therapy is an expensive treatment. To prevent unnecessary treatment, the prediction of the effect of rhGH therapy on a short term basis is important. The aim of this study was to find a good prognostic tool for prediction of the growth response to rhGH therapy.

\section{Methods}

\section{Subjects}

In this study children with GHD or SGA were included who were indicated for rhGH treatment according to the Dutch Growth Research Foundation. GHD children have to meet the following criteria:

- Negative deviation of the growth curve

- Delayed bone maturation measured by X-ray of the left hand

- $\mathrm{GH}$ concentration $<20 \mathrm{mU} / \mathrm{l}$ in 2 stimulation tests

- Insulin-like growth factor 1 (IGF-1) <-2 SD

- Inclusion criteria for SGA children to receive GH therapy were:

- Birth length or weight <-2 SD for gestational age

- Actual height $<-2.5$ SD according to the standard reference values ${ }^{14,15}$

- Age $\geq 4$ years

- Bone maturation $\leq 13$ years for girls or $\leq 15$ years for boys

- No signs of catch-up growth in previous year

- Actual height deviates > 1 SD from target height (TH)

- Children were excluded if other reasons than those related to GHD or SGA for growth retardation were present

- SGA children with GHD are excluded in this study

Parents and children were informed about the nature of the study and written consent was obtained. The study was approved by the Medical Ethical Committee of the Maastricht University Medical Centre (MUMC). 


\section{Study design}

The study design was a prospective cohort study with duration of follow-up of 12 months. End points: Primary end points were growth and body composition. Growth was assessed by the evaluation of height during one year. Body composition was assessed by measuring the total body water (TBW) by the Deuterium dilution method (doubly labeled water (DLW) method).

\section{Measurements}

\section{$\underline{\text { Height }}$}

Height and weight were measured at the start of therapy and at 3 months intervals during at least one year. Height was measured using a Harpenden stadiometer. Subject's shoes and socks were removed. A $0.5 \mathrm{~kg}$ weight was placed on the headboard to flatten hair. The patient was kept in the correct upright position, the 'Frankfurt plane', while a gentle upward pressure was exerted on the mastoid processes so that the patient was fully extended. Height was expressed in standard deviation score (SDS). The difference in SDS over one year $\left(\mathrm{SDS}_{\mathrm{t} 1}-\mathrm{SDS}_{\mathrm{t} 0}\right)$ was used to divide the patient group into adequate and inadequate responders. Weight was measured with an electronic scale with digital readings, accurate to 5 gram. Empty body weight was measured without clothing, directly after waking up and voiding.

\section{Deuterium dilution method (DLW method)}

Body composition was determined by measuring the TBW with the stable isotope of hydrogen (Deuterium), according to the Maastricht protocol ${ }^{16}$ at $\mathrm{t}=0$ and $\mathrm{t}=6$ weeks. A baseline urine sample was collected before the labeled water was consumed to determine the natural abundance of Deuterium in the urine. The child drank a known amount of the doubly labeled water in the evening, before it went to bed. Instructions were given to drink all the water and to rinse the bottle to be sure all the water is consumed. A second urine sample was collected after an overnight equilibration after the first voiding. TBW was calculated by the formula: $\mathrm{C}_{1} \mathrm{x} \mathrm{V}_{1}=\mathrm{C}_{2}$ $\mathrm{x} \mathrm{V}_{2}\left(\mathrm{C}_{1}=\right.$ concentration of label in ingested fluid, $\mathrm{V}_{1}=$ volume ingested fluid, $\mathrm{C}_{2}=$ concentration tracer in second urine sample, $\mathrm{V}_{2}=$ distribution volume). The distribution volume was divided by 1.04, because of the exchange of tracer with nonaqueous substances in the body, to calculate the TBW. Because patients with a different height were compared, the changes in TBW after 6 weeks were corrected for height in accordance with the Body Mass Index (TBW/height ${ }^{2}$ ). The difference of this value between $t_{0}$ and $t_{6}$ is plotted against the change in height SDS after one year of therapy.

Based on the mean response found by Ranke et al. ${ }^{17}$ a cut off value for good responders was determined as a change of more than 0.7 SDS over one year. In this study it was observed that during the first year on rhGH therapy the magnitude of 
the growth response was negatively correlated with chronological age and height SDS, and positively correlated with target height SDS, rhGH dose (IU $/ \mathrm{kg} /$ week) and frequency of GH injections. In this study only GHD children are examined. Furtado et al. ${ }^{18}$ found the same response in SGA children. In this study rhGH therapy was associated with a first year height increment of 0.67 SDS ( $p<0.01)$. Ranke et al found the following results for small for gestational age children, treated with $\mathrm{GH}$ treatment: Mean height velocity was 8.7 and $7.0 \mathrm{~cm} /$ year, corresponding to a height increment of 0.7 and 0.3 SD scores, in the first and second year of GH treatment, respectively $^{19}$.

The rhGH dose which was given in our study is 35 microgram/kilogram for GHD and for SGA children. When taking the cut off value of 0.7 SDS for granted, we found the best results at a cut off value of $0.7 \mathrm{l} / \mathrm{m}^{2}$ for the change in body composition, because at this level the number of correct predictions was the highest. In the previous study of Hoos et al. ${ }^{13}$, the best result was found at a cut off value of $0.9 \mathrm{l} / \mathrm{m}^{2}$ for the change in body composition.

\section{Statistics}

We used a cut off value of $0.7 \mathrm{l} / \mathrm{m}^{2}$ for the change in body composition, because at this level the highest and the maximum sensitivity and specificity was reached. This value has been detected by calculating the sensitivity and specificity for different cut off values.

Sensitivity was calculated by: Number of true positives / (Number of true positives + Number of false negatives). Specificity was calculated by: Number of true negatives / (Number of true negatives + Number of false positives).

Two sample t-tests were used to evaluate differences between two groups.

\section{Results}

In total 192 children were included, of which five patients dropped out because they stopped treatment due to poor compliance or did not appear on appointments. Of the remaining 187 patients, 88 patients were GHD and 99 were SGA. Patient characteristics are given in Table 1 . The children were divided into two groups according to their diagnosis. There was an increase in height of 0.832 and 0.874 SDS after one year of treatment in respectively the GHD and the SGA children, which is not significantly different. The body composition according to the calculation of TBW divided by height ${ }^{2}$ in SGA children was significantly lower compared to the GHD children $\left(9.02 \mathrm{l} / \mathrm{m}^{2}\right.$ and $\left.9.6 \mathrm{l} / \mathrm{m}^{2}, \mathrm{p}<0.001\right)$. The change in body composition within the GHD group was 0.94 and within the SGA children the change in body 
composition was $0.68(\mathrm{p}=0.001)$. This value is based on the mean difference of body composition before start of rhGH therapy (TBW / Height ${ }^{2}$ ) and after 6 weeks of rhGH therapy (TBW / Height ${ }^{2}$ ) within the GHD group and within the SGA group.

Table 1: Baseline characteristics

\begin{tabular}{llll}
\hline & GHD & SGA & P-value \\
& $\mathrm{n}=88$ & $\mathrm{n}=99$ & \\
\hline Age (years) & $8.30( \pm 3.6)$ & $6.68( \pm 2.5)$ & \\
Height before therapy (SDS) & $-2.74( \pm 0.99)$ & $-3.27( \pm 0.69)^{*}<0.001$ \\
Height after 1 year (SDS) & $-1.91( \pm 0.92)$ & $-2.40( \pm 0.73)^{*}<0.001$ \\
Mean difference in height $\left(\mathrm{SDS}_{\text {1year }}-\mathrm{SDS}_{\text {start }}\right)$ & $0.832( \pm 0.50)$ & $0.874( \pm 0.33)$ & 0.509 \\
Body composition before therapy $(\mathrm{TBW} /$ height & & \\
Body composition at 6 weeks $\left(\mathrm{TBW} /\right.$ height $\left.^{2}\right)$ & $9.60( \pm 1.31)$ & $9.02( \pm 1.06)^{*}<0.001$ \\
Mean difference body comp $\left(\mathrm{TBW} / \mathrm{height}^{2}\right)$ & $10.54( \pm 1.39)$ & $9.70( \pm 1.10)^{*}<0.001$ \\
\hline
\end{tabular}

Values are means \pm standard deviation

* significant difference compared to GHD

Figure 1 shows the change in TBW divided by height ${ }^{2}$ over 6 weeks, plotted against the change in height during one year (SDS) for the GHD children. Two lines are shown. The reference line on the x-axis represents a change in height SDS of 0.7, which is the cut off value chosen between good $(n=51)$ and poor $(n=37)$ responders. The reference line on the y-axis represents the cut off value of the change in TBW/height ${ }^{2}$ of $0.7 \mathrm{l} / \mathrm{m}^{2}$. The four quadrants represent the true positive (B), false negative (C), true negative (D) and false positive (A) results. Based on the chosen cut off values, the sensitivity of TBW/height ${ }^{2}$ was $87 \%$ and the specificity $58 \%$. The positive and negative predictive value is $73 \%$ and $75 \%$ respectively. The same is done in figure 2 for children born SGA, in which 25 had a poor growth response and 74 had a good growth response according to the cut off value of 0.7 SDS. This gives a sensitivity of $53 \%$ and a specificity of $83 \%$, with a positive predictive value of $90 \%$ and a negative predictive value of $32 \%$ when using the cut off value of TBW $/$ height $^{2}$ of $0.7 \mathrm{l} / \mathrm{m}^{2}$. 


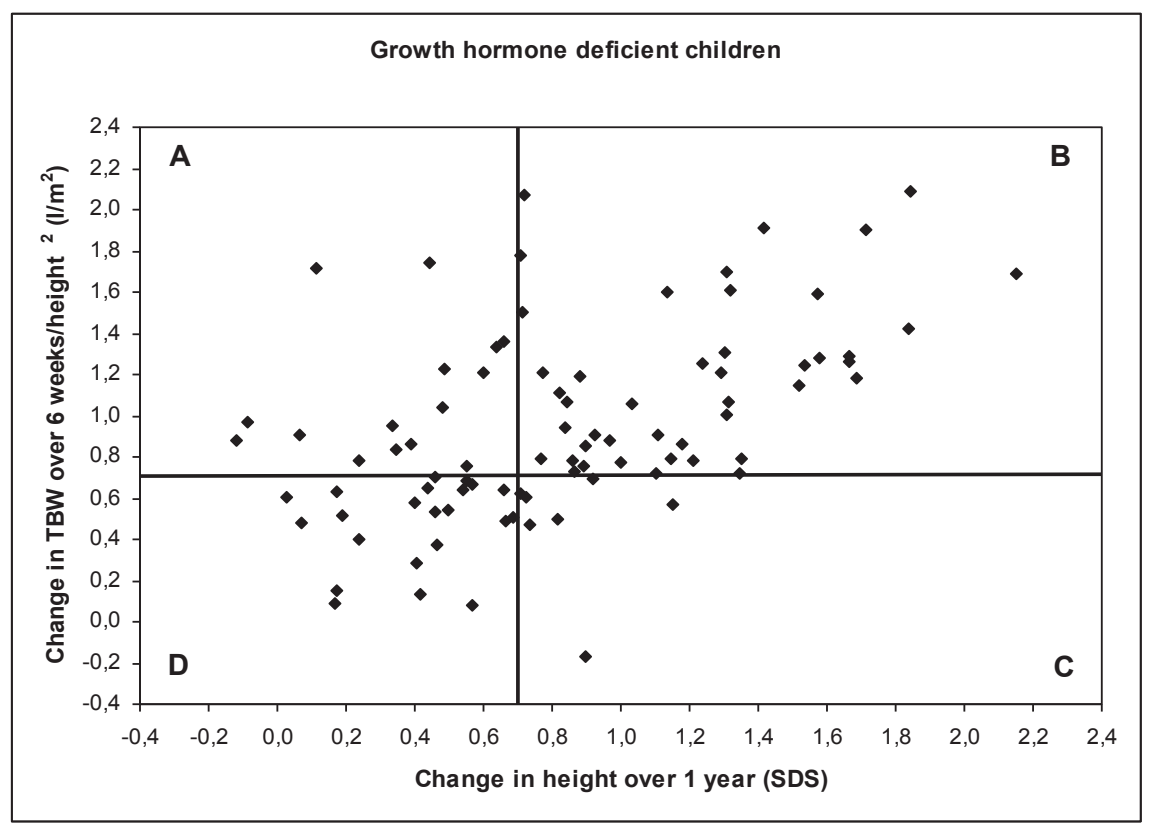

Figure 1: Relation between total body water (TBW) and height for growth hormone deficient (GHD) children. $\mathrm{A}=$ false positive, $\mathrm{B}=$ true positive, $\mathrm{C}=$ false negative, $\mathrm{D}=$ true negative.

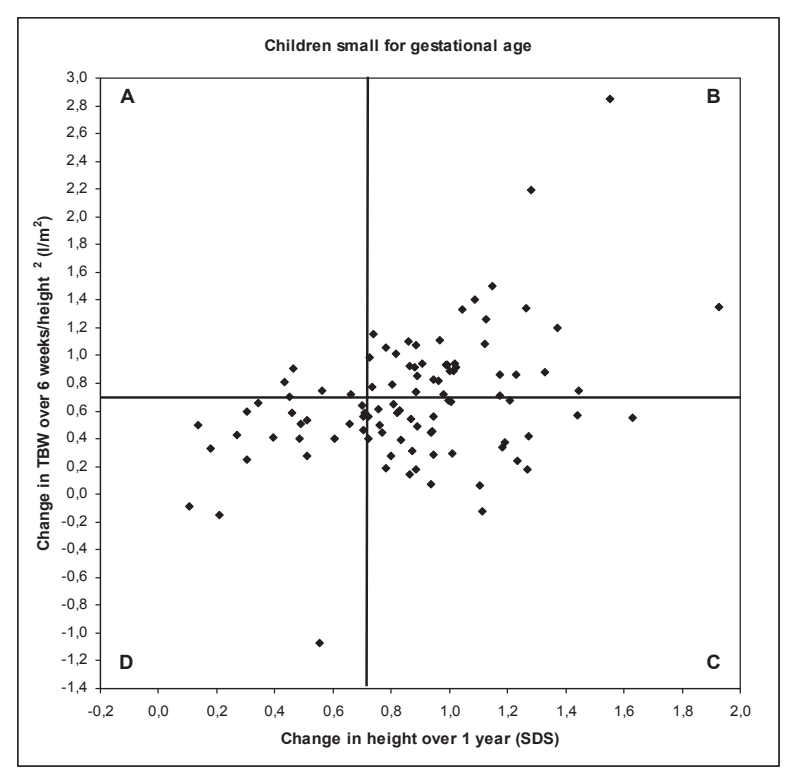

Figure 2: Relation between total body water (TBW) and height for children born small for gestational age $(\mathrm{SGA}) . \mathrm{A}=$ false positive, $\mathrm{B}=$ true positive, $\mathrm{C}=$ false negative, $\mathrm{D}=$ true negative. 


\section{Discussion}

The present study evaluates the use of changes in body composition after 6 weeks for the prediction of the effect of rhGH treatment on growth after one year. In an earlier study of Hoos et al. ${ }^{13}$ a change in body composition proved to be valuable for the distinction between good and poor responders to rhGH treatment in 28 children with GHD. In this study the same cut off value ${ }^{17}$ for growth response was taken and the connection with the change in body composition was evaluated in a larger cohort of GHD children. At the same time this was done in children born SGA without spontaneous catch up growth.

Conform the study of Hoos et al. ${ }^{13}$ we used the Deuterium dilution method to estimate the TBW. Because in this technique the Deuterium as well as the collected urine could be transported by mail, it was easy possible to conduct a nationwide study. The TBW was used instead of the FFM because the hydration level of the FFM, which in adults is assumed to be $73 \%$, is age-dependent and not reliable enough in children. To interpret the TBW in patients who differ in height, the results are corrected for height as TBW/height ${ }^{2}$, in accordance with the Body Mass Index (BMI). The TBW was not corrected for weight, because height was the discriminating factor for good and poor responders and accepted as a more constant factor over a period of 6 weeks.

The change in TBW correctly predicted the growth response in $75 \%$ of the GHD patients (Figure 1, quadrant B and D). To use this method as a predictor of the growth response, the positive and negative predictive values are most important. If the child has a change in TBW of $>0.7 \mathrm{l} / \mathrm{m}^{2}$, the chance to have a good growth reaction is $73 \%$ (positive predictive value). The negative predictive value $75 \%$ suggests that if a child shows a low increase in TBW/height ${ }^{2}$, the expectation is that this child will not grow more than 0.7 SDS in one year. At the same time $8 \%$ will have a false negative test result. Whether the change in body composition of $<0.7 \mathrm{l} / \mathrm{m}^{2}$ is a reason to stop treatment with rhGH is under discussion, because the cut off value of 0.7 SDS is based on the mean response value in literature, but is in fact arbitrary.

The reason for the different cut off value in both studies is probably based on the difference in the amount of children included. In the study of Hoos, only 28 GHD children are involved. In our study 88 GHD children are involved.

In SGA children the relation of a change in body composition with the growth reaction is less clearly demonstrated, although they have a comparable growth reaction compared to the GHD children (mean growth response of 0.832 SDS versus 0.874 SDS). In SGA children a change in TBW of $>0.7 \mathrm{l} / \mathrm{m}^{2}$ is strongly predictive for a growth response of more than 0.7 SDS in one year (Figure 2 quadrant B, positive 
predictive value: 90\%). On the other hand they were indistinguishable from each other when TBW was $<0.7 \mathrm{l} / \mathrm{m}^{2}$ (Figure 2 quadrant $\mathrm{C}$ and $\mathrm{D}$, negative predictive value: $32 \%$ ). Based on these results, the change in TBW $<0.7 \mathrm{l} / \mathrm{m}^{2}$ in SGA children is not a tool to decide to stop treatment with rhGH treatment, but a change in TBW $>0,7 \mathrm{l} / \mathrm{m}^{2}$ is highly predictable for a good response to therapy.

In this study different results are seen between GHD children and children born SGA. GHD children show a lower FFM/ heigt ${ }^{2}$ and thereby a higher fat mass (FM) before start of any treatment, compared to SGA children who show a higher FFM/heigt ${ }^{2} 4,5$. The treatment with rhGH causes a shift in body composition towards the FFM in GHD children, possibly because their amount of fat deposit is much higher than in SGA children. Another possible explanation could be that SGA children do not have a growth hormone deficiency. The effect of rhGH treatment is therefore less obvious than in GDH children.

Also a possible metabolic factor could be involved. One of the factors mentioned with respect to the stunted growth of SGA children is reduced sensitivity for IGF-1 (insulin-like growth factor 1$)^{20}$. IGF-1 is mainly secreted by the liver as a result of stimulation by growth hormone. IGF-1 expression is required for achieving maximal growth. Short SGA children show plasma IGF-1 levels that are in the lower normal range ${ }^{21}$.

The above mentioned factors could possibly explain why SGA children show less increase of TBW/height ${ }^{2}$ as response to treatment, despite their increase in height. In SGA children this shift can be seen less obvious.

Other methods for measuring body composition in GHD or SGA children are evaluating the change in body mass index (BMI) or evaluating the change in weight for height (SDS) after one year of treatment. In the study of Ernst et al. ${ }^{22}$ is found that the mean change in BMI $\left(\mathrm{kg} / \mathrm{m}^{2}\right)$ after 1 year of $\mathrm{rhGH}$ treatment is $-0,04 \mathrm{~kg} / \mathrm{m}^{2}$. The mean change in weight for height (SDS), after 1 year of rhGH treatment is 0,11 . Apparently, BMI and weight for height of SGA children barely change during the first year of rhGH treatment. Therefore, the TBW method is much more appropriate than the other described methods. Another method of measuring TBW is the underwater weighting. This method is not practically achievable and is not used in this study. Changes in TBW under influence of rhGH treatment are also dependent on other factors like age, sexe and diet. These are determinants of $\mathrm{TBW}^{23}$. 


\section{Conclusion}

In conclusion, changes in body composition data proved to be valuable for the distinction between adequate and inadequate responders to GH therapy. In GHD children the adequate responders are distinguished by a change in TBW/height ${ }^{2}$ below $0.7 \mathrm{l} / \mathrm{m}^{2}$, in SGA children the adequate responders are distinguished by a change in TBW/height ${ }^{2}$ exceeding $0.7 \mathrm{l} / \mathrm{m}^{2}$. It should be realized that the cut off values for growth response as well as change in body composition are more or less arbitrary, although the findings in this study show that a change in body composition is an actual tool in further predicting the individual response on rhGH treatment. 


\section{References}

1. Argente J, Mehls 0 , et al. Growth and body cpmposition in very young SGA children Pediatr Nephrol $2010 ; 25: 679-685$.

2. Centraal Begeleidingsorgaan voor de Intercollegiale Toetsing. Consensus Diagnostiek kleine lichaamslengte bij kinderen; 1996.

3. Boot AM, Engels MA, et al. Changes in bone mineral density, body composition, and lipid metabolism during growth hormone $(\mathrm{GH})$ treatment in children with GH deficiency. J Clin Endocrinol Metab 1997; 82:2423-2428.

4. Lapillonne A, Braillon $\mathrm{P}$, et al. Body composition in appropriate and in small for gestational age infants. Acta Paediatr 1997; 86(2):196-200.

5. Willemsen RH, Arends NJT, et al. Long-term effects of growth hormone (GH) treatment on body composition and bone mineral density in short children born small-for-gestational-age: six-year follow-up of a randomized controlled GH trial. Clinical Endocrinology 2007; 67:485-492.

6. Snel YE, Doerga ME, et al. Resting metabolic rate, body composition and related hormonal parameters in growth hormone-deficient adults before and after growth hormone replacement therapy. Eur J Endocrinol 1995; 133:445-450.

7. Roemmich JN, Huerta MG, et al. Alterations in body compositions and fat distribution in growth hormone-deficient prepubertal children during growth hormone therapy. Metabolism 2001; 50:537-547.

8. Collipp PJ, Curti V, et al. Body composition changes in children receiving human growth hormone. Metabolism 1973; 22:589-595.

9. Gregory JW, Greene SA, et al. Changes in body composition and energy expenditure after six weeks' growth hormone treatment. Arch Dis Child 1991; 66: 598-602.

10. Hassan M, Kohno H, et al. Body composition, atherogenic risk factors and apolipoproteins following growth hormone treatment. Acta Paediatr 1996; 85:899-901.

11. Leger J, Carel C, et al. Magnetic resonance imaging evaluation of adipose tissue and muscle tissue mass in children with growth hormone (GH) deficiency, Turner's syndrome, and intrauterine growth retardation during the first year of treatment with GH. J Clinical Endocrinol Metab 1994; 78:904-909.

12. Vaisman N, Zadik Z, et al. Changes in body composition, resting energy expenditure, and thermic effect of food in short children on growth hormone therapy. Metabolism 1994; 43:1543-1548.

13. Hoos MB, Westerterp KR,et al. Short-term effects of growth hormone on body composition as a predictor of growth. J Clin Endocrinol Metab 2003; 88:2569-2572.

14. Gerver WJM, de Bruin R: Paediatric Morphometrics, a reference manual (second extended edition). in Universitaire pers Maastricht. Maastricht; 2004.

15. Fredriks AM: Growth Diagrams. Fourth Dutch Nation-Wide Survey, 1997. Thesis, Leiden University 2004; 258.

16. Westerterp KR, Wouters L, et al. The Maastricht protocol for the measurement of body composition and energy expenditure with labeled water. Obes Res 1995; 3:49-57.

17. Ranke MB, Guilbaud 0: Growth response in prepubertal children with idiopathic growth hormone deficiency during the first two years of treatment with human growth hormone. Analysis of the Kabi Pharmacia International Growth Study. Acta Paediatr Scand Suppl 1991; 379:90-115.

18. Furtado AC, Castro LC, et al. Clinical predictors of growth response in the first year of treatment with a fixed dose of growth hormone in children born small for gestational age. Arq Bras Endocrinol Metabol 2010; 54(5):443-448.

19. Ranke B, Lindberg A, et al. Prediction of response to growth hormone treatment in short children, born small for gestational age: Analysis of data from KIGS (Pharmacia international growth data base). J Clinical Endocrinol Metab 2003; 88 (1):125-131.

20. Zegher de F, Francois L, et al. Growth hormone treatment of short children born small for gestational age. Trends Endocrin Metab 1998; 9(6):233-237.

21. Volkl TM, Schwobel K, et al. Spontaneous growth hormone secretion and IGF1:IGFBP3 molar rations in children born small for gestational age (SGA). Growth Horm IGF Res 2004; 14(6):455-461. 
22. Ernst MAB, Van der Hoeven MAHBM, et al. Body proportions and body compsition in small for gestational age children after receiving growth hormone treatment.

23. Owen GM, Jensen RL, et al. Influence of age, sex and diet on total body watermof four-to sevenmonth old infants. Annals of the New York Academy of Sciences 1963; vol. 110 part II:861-864. 


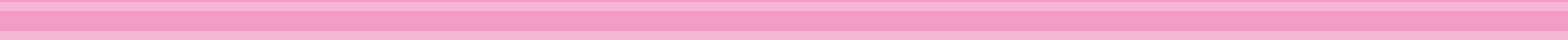

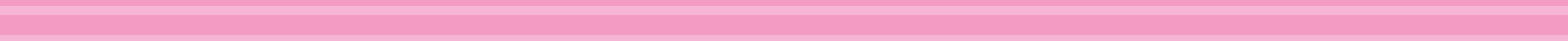

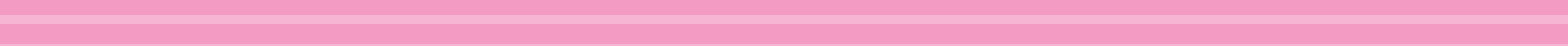

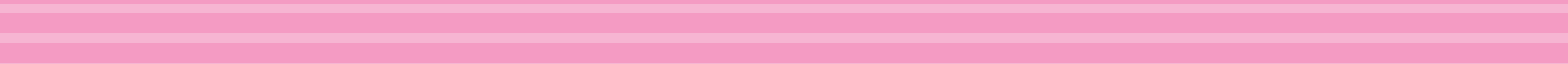

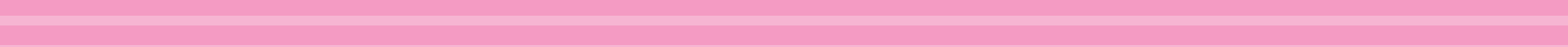

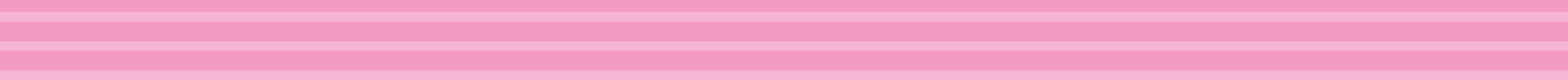

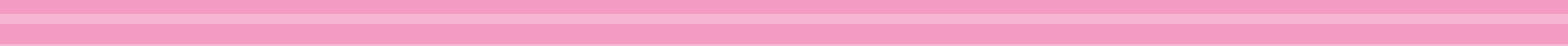

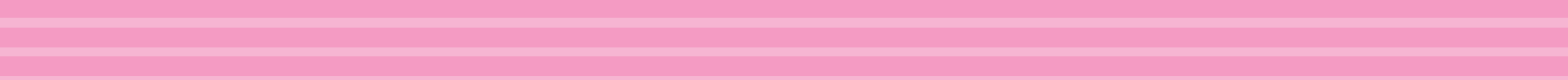

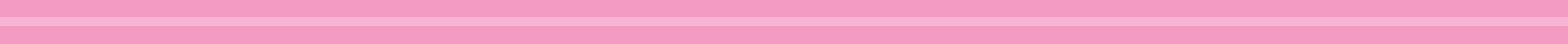

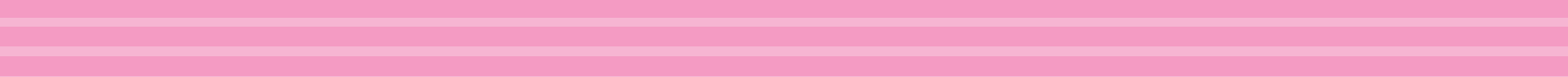

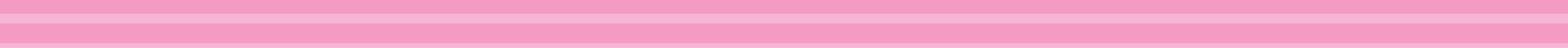

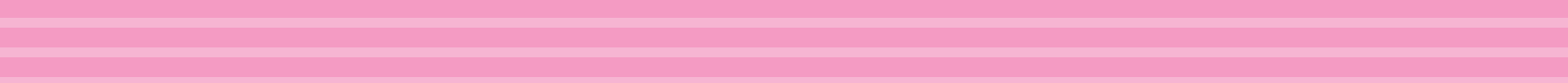

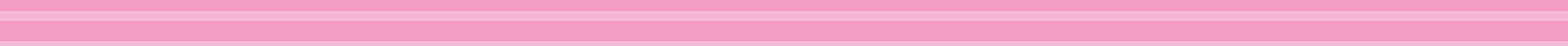

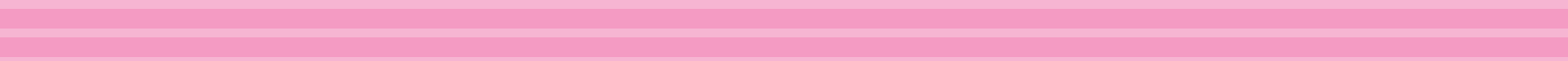

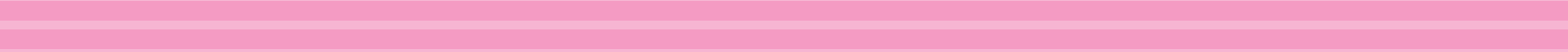

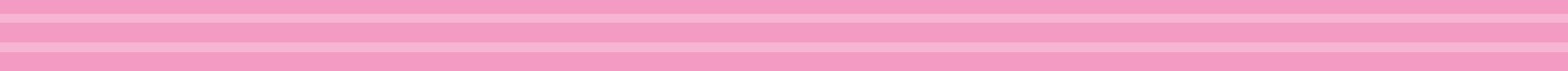

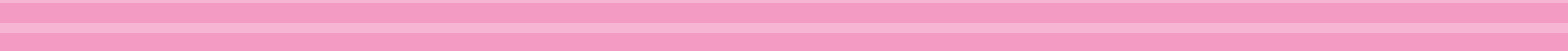

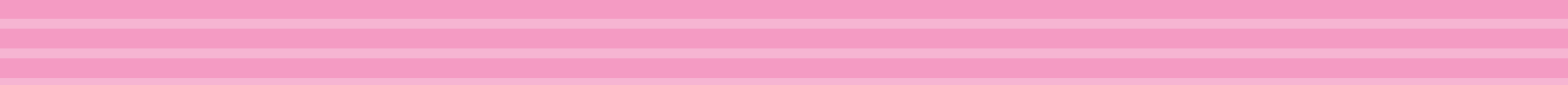

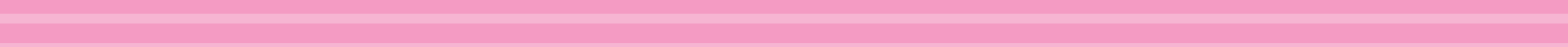

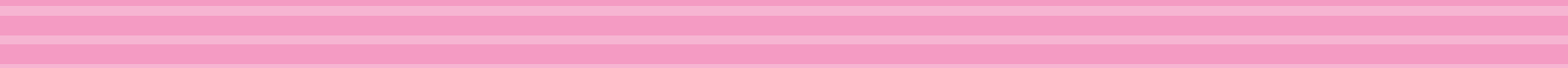

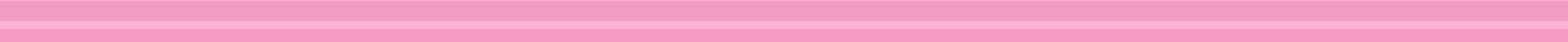

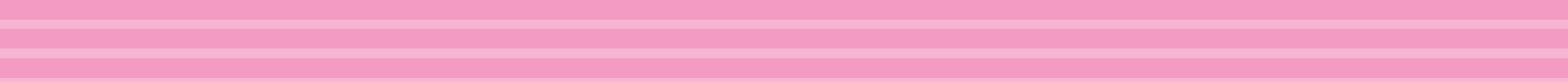

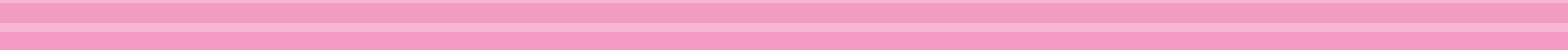

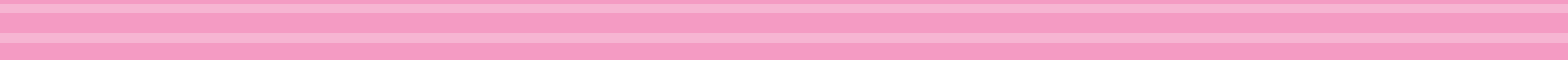

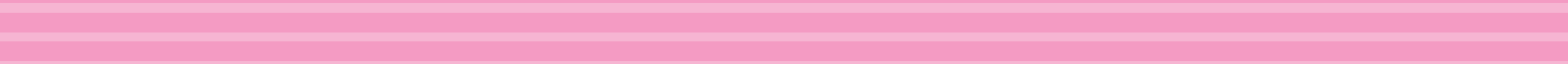

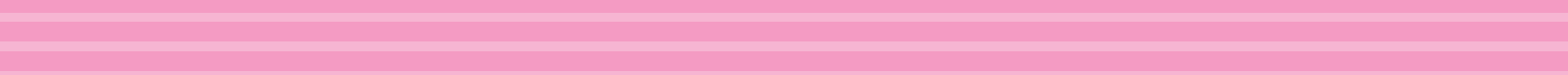

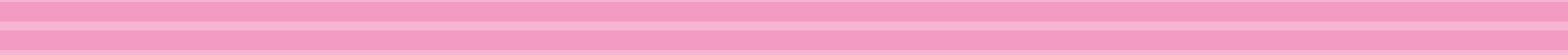
(2) 


\section{CHAPTER 4}

BODY PROPORTIONS IN SMALL FOR GESTATIONAL AGE CHILDREN AFTER RECEIVING GROWTH HORMONE TREATMENT
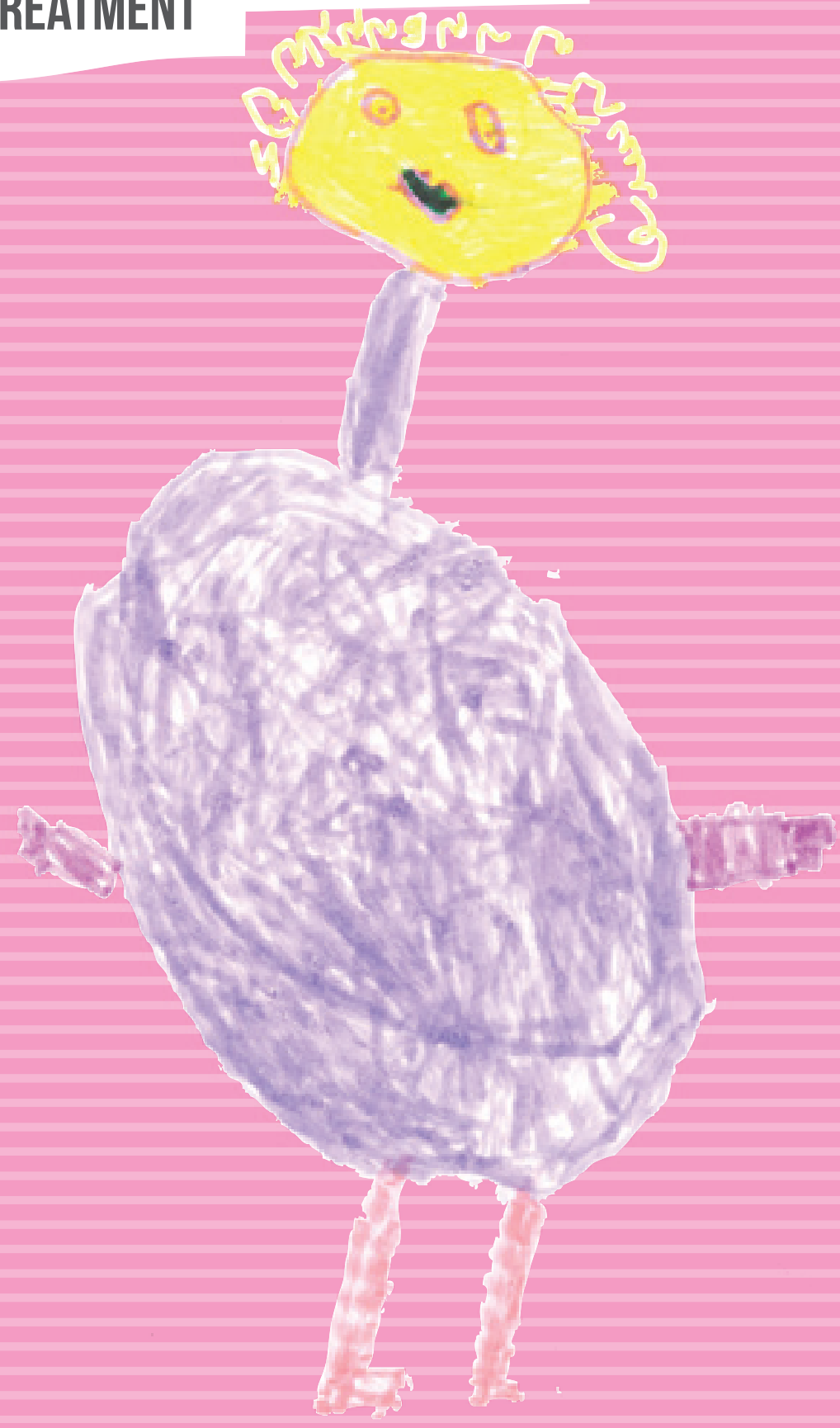
CHAPTER 4 


\section{CHAPTER 4}

\section{Body proportions in small for gestational age children after receiving growth hormone treatment}

It is generally accepted that children born small for gestational age (SGA) have a higher risk to develop the metabolic syndrome with insulin resistance and cardiovascular diseases. At the same time it is know that a lot of SGA children show an accelerating weight gain, but no abnormal gain in length. The same is true for an increasing number of children born appropriate for gestational age (AGA) who develop obesity. As described in the previous chapter there is no secular trend in weight and length during the perinatal period. Therefore, there seems to be a common factor in the growth of both infant groups, SGA and AGA. The SGA children who not correct their length during the first years of life and end up at the age of four years with height below two standard deviations, are eligible for treatment with recombinant human growth hormone (rhGH). It is of interest to investigate if these SGA children will change their body proportions in the sense of body mass index (BMI) after receiving rhGH. To examine the pattern of changes in body proportions BMI and weight for height SDS values after 1 year of rhGH treatment were calculated. As golden standard of the body composition in the sense of fat-free mass, the Deuterium dilution method was applied. The change of the body composition after treatment with rhGH measured by the Deuterium method is compared with the change in BMI. The results of this comparison are important in the approach to the prevention of the metabolic syndrome in SGA children as well as in the AGA children. Evidently the simple measurement of the BMI is a good tool for health care practitioners not only in the SGA group but also in the AGA children.

This chapter is submitted for publication by:

Manon AB Ernst, Angèle JGM Gerver, Luc JI Zimmermann, Willem JM Gerver. 
CHAPTER 4 


\section{Introduction}

The common definition of small for gestational age (SGA) children refers to a birth weight below the $10^{\text {th }}$ percentile for gestational age ${ }^{1}$. Researchers suggest that low birth weight followed by rapid weight gain during early postnatal life is associated with long-term risks for central obesity, insulin resistance and cardiovascular diseases, known as the metabolic syndrome ${ }^{2,3}$. Other studies indicate that not only accelerated $^{4}$, but also decelerated ${ }^{5}$ weight gain in these infants is associated with a risk on the metabolic syndrome. Therefore, an accurate follow up of the growth of SGA children is necessary and should be performed by a physician known with consequences of abnormal growth in childhood. This is even more important realizing that growth velocity in SGA children is different from normal weight children. In SGA children, both weight and length remain behind during their first year of life but thereafter most children show a catch-up growth in weight beyond the normal range for non-SGA children, which can be partly explained by a regression to the mean. However, a large part of the SGA children show faster acceleration in their weight gain compared to their length which discrepancy is estimated as an extra risk factor for overweight at the age of 5 years ${ }^{6}$.

Those children who do not correct their length spontaneously are eligible for treatment with recombinant human growth hormone (rhGH). Treatment with rhGH based on the indication criteria reviewed by the Dutch Growth Research Foundation ${ }^{7}$, is an effective and safe approach to reduce the adult height deficit that short SGA children otherwise face ${ }^{8}$. In GHD children it is shown that besides its positive effect on growth, rhGH also influences metabolism ${ }^{9,10}$. The basal metabolic rate increases ${ }^{11}$, visible as a change in body composition by an increase in fat-free mass $(\mathrm{FFM})^{12}$. rhGH treatment of SGA children also results in a decline in fat mass (FM) and an increase in FFM, which is consistent with the lipolytic and anabolic properties of rhGH treatment ${ }^{13}$. In a study of Hoos et al the change in body composition in GHD children was already detectable after 6 weeks of treatment with $\mathrm{rhGH}^{14}$ as measured by total body water (TBW) with the Deuterium dilution method. A nationwide study revealed that treatment with rhGH changes the body composition in SGA children too, but less compared to GHD children ${ }^{15}$. This can be possibly explained because SGA children have a reduced body fat percentage before treatment with rhGH in contrast to GHD children whose body fat percentage is increased $^{16,17}$. In addition SGA children have a reduced sensitivity for IGF-1 (insulin-like growth factor 1) unlike GHD children ${ }^{18}$. Therefore, in SGA children, a decrease in FM can hardly be expected and mainly an increase in FFM can be measured. Although the Deuterium method is accepted as a golden standard to measure TBW, in SGA children it seems therefore less accurate to estimate the effect of rhGH treatment. 
In this study, we analyze the growth pattern, expressed as BMI and weight for height values of SGA children, treated with rhGH and compare the results with the Deuterium TBW study ${ }^{14}$ to evaluate which method offers the highest accuracy in estimating the change in body composition in SGA children treated with rhGH.

\section{Methods}

\section{Inclusion}

Data for this study were collected at the department of Pediatrics at the academic hospital of Maastricht, in the South of The Netherlands. Included were SGA children who met the inclusion criteria reviewed by the Dutch Growth Research Foundation ${ }^{7}$ : Birth length or weight: <-2 standard deviation (SD) for gestational age, actual height: < -2.5 SD and/or deviating > 1 SD from target height (TH), age: > 4 years, bone maturation: $\leq 13$ years in girls and $\leq 15$ years in boys, no signs of catch-up growth in the previous year.

Exclusion criteria include: Evident dimorphism suggestive for an (un)known syndrome or chromosomal anomaly, skeletal dysplasia or severe disproportion, severe complications after birth or during the first weeks of life with current lung problems, nutritional deficiencies or malabsorption, untreated endocrinological anomalies, untreated chronic systemic or organ diseases or use of medication with negative effect on growth, suspicion of emotional deprivation, active malignancy or severe psychomotoric retardation.

\section{Measurements}

Measurements of weight and height were taken at start of rhGH treatment and 1 year thereafter with a variance of 1 month.

Height was measured with the Harpenden stadiometer, weight with an electronic scale with digital readings accurate to 5 gram.

BMI was calculated as:

$$
\mathrm{BMI}=\frac{\text { weight }_{k g}}{\text { height }_{m}^{2}}
$$

The values of weight, height, BMI as well as weight for height were expressed in terms of standard deviation scores (SDS): 


$$
S D S_{t}=\frac{x_{t}-m_{t}}{s_{t}}
$$

where $\mathrm{x}_{\mathrm{t}}$ denotes body measurement score at age $\mathrm{t}, \mathrm{m}_{\mathrm{t}}$ the population mean at age $\mathrm{t}$ and $s_{t}$ the SD of the reference population at age $t$. As reference population the Dutch reference values of Gerver et al. were used ${ }^{19}$.

As the metabolic effect parameter, total body water (TBW) was measured with the Deuterium dilution technique before and at 6 weeks after start of therapy. To interpret total body water in individuals who differed in height, the results were corrected for height as TBW/height ${ }^{2}$. Total body water was measured with the stable isotope of hydrogen according to the Maastricht protocol ${ }^{20}$ and calculated by

$$
C_{1} \times V_{1}=C_{2} \times V_{2}
$$

$\mathrm{C}_{1}=$ concentration of the label in the ingested fluid

$\mathrm{V}_{1}=$ volume of the dose

$\mathrm{C}_{2}=$ concentration of the tracer in the sample

$\mathrm{V}_{2}=$ distribution volume in the body

Due to the exchange of the tracer with non-aqueous substances in the body, $V_{2}$ has to be divided by 1.04 to determine TBW.

A comparison was made between the change in TBW after six weeks with the change in BMI after 1 year of treatment with rhGH (Figure 1). We also compared the change in TBW after six weeks with the change in weight for height, 1 year after treatment with rhGH (Figure 2).

\section{Results}

We included 22 SGA children in our study population. Those children met the criteria to receive rhGH treatment. The mean change in BMI after 1 year of rhGH treatment was $-0.04 \mathrm{~kg} / \mathrm{m}^{2}$. The mean change in SDS in weight for height values for these children after 1 year of rhGH treatment was $0.11 \mathrm{SD}$.

Because two individuals showed deviating values, these values were excluded in our next calculations. The mean age of the remaining 20 children at which rhGH treatment started was: 5.5 years.

The mean change in BMI after 1 year of rhGH treatment was $0 \mathrm{~kg} / \mathrm{m}^{2}$. The mean change in SDS in weight for height values for these children after 1 year of rhGH treatment was 0.17 SD and the mean change in SDS in height values for these chil- 
dren after 1 year of rhGH treatment was 0.81 SD (Table 1). After 6 weeks of rhGH treatment, the mean change in TBW was $0,62 \mathrm{l} / \mathrm{m}^{2}$.

Table 1: Age, BMI $\left(\mathrm{kg} / \mathrm{m}^{2}\right)$, SDS values of weight, height and weight for height of SGA children, at start of rhGH treatment and change in TBW/ height ${ }^{2}\left(1 / \mathrm{m}^{2}\right), 6$ weeks after rhGH treatment, change in BMI $\left(\mathrm{kg} / \mathrm{m}^{2}\right)$ and change in SDS values of height and weight for height after 1 year of rhGH treatment.

\begin{tabular}{|c|c|c|c|c|c|c|c|c|c|}
\hline ID & Age & $\begin{array}{c}\text { BMI } \\
\left(\mathrm{kg} / \mathrm{m}^{2}\right)\end{array}$ & $\begin{array}{l}\text { Weight } \\
\text { (SDS) }\end{array}$ & $\begin{array}{l}\text { Height } \\
\text { (SDS) }\end{array}$ & $\begin{array}{l}\text { Weight } \\
\text { for height } \\
\text { (SDS) }\end{array}$ & $\begin{array}{c}\text { Change in } \\
\text { TBW/ } \\
\text { height }^{2} \\
\left(1 / \mathrm{m}^{2}\right)\end{array}$ & $\begin{array}{c}\text { Change in } \\
\text { BMI } \\
(\mathrm{kg} / \mathrm{m} 2)\end{array}$ & $\begin{array}{l}\text { Change in } \\
\text { weight } \\
\text { for height } \\
\text { (SDS) }\end{array}$ & $\begin{array}{c}\text { Change in } \\
\text { height } \\
\text { (SDS) }\end{array}$ \\
\hline & $\begin{array}{l}\text { at start } \\
\text { rhGH } \\
\text { treatment }\end{array}$ & $\begin{array}{c}\text { at start } \\
\text { rhGH } \\
\text { treatment }\end{array}$ & $\begin{array}{l}\text { at start } \\
\text { rhGH } \\
\text { treatment }\end{array}$ & $\begin{array}{l}\text { at start } \\
\text { rhGH } \\
\text { treatment }\end{array}$ & $\begin{array}{l}\text { at start } \\
\text { rhGH } \\
\text { treatment }\end{array}$ & $\begin{array}{c}6 \text { weeks } \\
\text { after } \\
\text { rhGH } \\
\text { treatment }\end{array}$ & $\begin{array}{l}1 \text { year } \\
\text { after } \\
\text { rhGH }\end{array}$ & $\begin{array}{l}1 \text { year } \\
\text { after } \\
\text { rhGH }\end{array}$ & $\begin{array}{l}1 \text { year } \\
\text { after } \\
\text { rhGH }\end{array}$ \\
\hline 1 & 6.60 & 15.40 & -2.51 & -3.41 & -0.30 & 0.37 & -0.40 & 0.37 & 1.19 \\
\hline 2 & 9.20 & 14.76 & -2.13 & -3.20 & -0.23 & 0.73 & 0.50 & 0.37 & 0.89 \\
\hline 3 & 9.20 & 13.53 & -2.15 & -2.43 & -1.07 & 0.42 & 0.20 & 0.30 & 1.27 \\
\hline 4 & 5.10 & 14.30 & -2.91 & -3.10 & -1.18 & 0.75 & -0.50 & -0.43 & 0.56 \\
\hline 5 & 6.10 & 15.42 & -2.37 & -3.15 & -0.31 & 0.45 & -0.30 & -0.18 & 0.94 \\
\hline 6 & 4.20 & 13.30 & -3.51 & -3.45 & -1.71 & 0.79 & -0.90 & -0.31 & 0.80 \\
\hline 7 & 9.10 & 14.92 & -1.70 & -2.37 & -0.05 & 1.01 & 0.40 & 0.65 & 0.82 \\
\hline 8 & 4.00 & 16.19 & -2.14 & -3.39 & 0.30 & 0.93 & 0.20 & 0.15 & 0.99 \\
\hline 9 & 6.00 & 16.55 & -1.60 & -2.87 & 0.89 & 0.86 & -0.30 & 0.07 & 1.17 \\
\hline 10 & 5.20 & 16.34 & -1.68 & -2.81 & 0.49 & 0.89 & -1.50 & 0.32 & 1.01 \\
\hline 11 & 5.20 & 16.30 & -1.36 & -3.26 & 0.83 & 0.29 & -0.30 & 0.36 & 1.01 \\
\hline 12 & 11.00 & 15.15 & -2.02 & -2.64 & -0.09 & 0.65 & 0.40 & -0.09 & 0.34 \\
\hline 13 & 7.50 & 14.06 & -2.46 & -3.71 & -0.75 & 0.72 & 1.10 & 0.18 & 0.66 \\
\hline 14 & 4.00 & 14.57 & -2.72 & -3.17 & -0.85 & 0.70 & -0.60 & 0.24 & 0.45 \\
\hline 15 & 8.10 & 12.86 & -2.45 & -2.75 & -1.56 & 0.53 & 0.10 & 0.02 & 0.51 \\
\hline 16 & 10.40 & 15.18 & -2.07 & -3.13 & 0.25 & 0.51 & 0.10 & 0.38 & 0.49 \\
\hline 17 & 4.00 & 13.01 & -4.43 & -4.94 & -1.77 & 0.56 & 0.70 & 0.27 & 0.70 \\
\hline 18 & 4.00 & 13.11 & -3.52 & -3.39 & -1.81 & 0.50 & 0.70 & 0.29 & 0.76 \\
\hline 19 & 4.70 & 13.00 & -3.22 & -2.62 & -2.15 & 0.31 & -0.10 & -0.20 & 0.87 \\
\hline 20 & 6.80 & 12.90 & -3.70 & -3.57 & -2.34 & 0.46 & 0.50 & 0.65 & 0.70 \\
\hline mean & 6.52 & 14.54 & -2.53 & -3.17 & -0.67 & 0.62 & 0 & 0.17 & 0.81 \\
\hline SD & 2.29 & 1.27 & 0.80 & 0.56 & 1.00 & 0.21 & 0.62 & 0.29 & 0.26 \\
\hline
\end{tabular}

$\mathrm{BMI}=$ Body Mass Index, SDS = standard deviation score, rhGH = recombinant human growth hormone 
Figure 1 shows the change in BMI after 1 year of rhGH treatment, plotted against the change in TBW, 6 weeks after rhGH treatment for the SGA children. 55\% of SGA children showed an increase in BMI after 1 year of rhGH treatment. The range of difference in BMI varies from a decrease of 1.5 to an increase of 1.1. All children showed an increase in TBW.

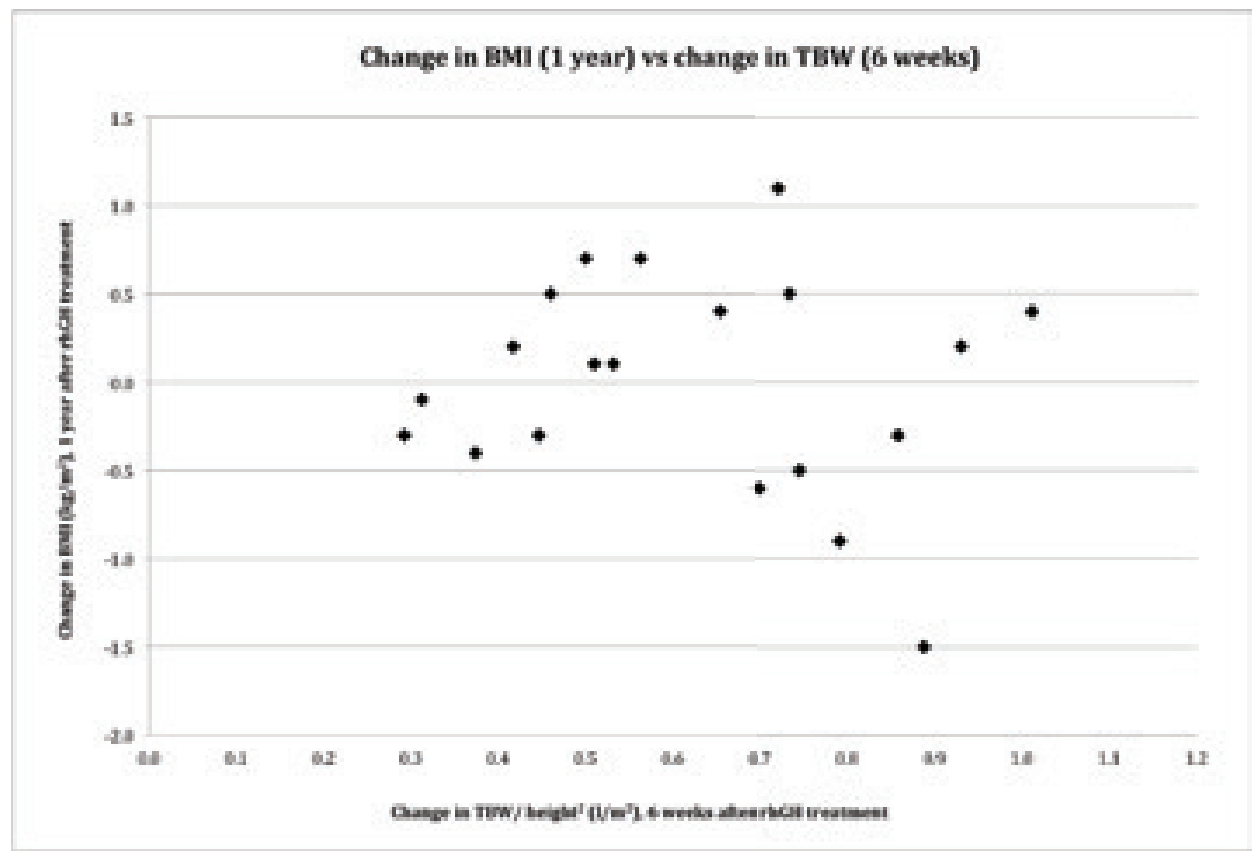

Figure 1: Change in BMI $\left(\mathrm{kg} / \mathrm{m}^{2}\right)$ after 1 year of rhGH treatment, plotted against TBW/ height ${ }^{2}\left(1 / \mathrm{m}^{2}\right), 6$ weeks after the start of rhGH treatment

In Figure 2, the change in weight for height 1 year after treatment, is compared with changes in TBW, 6 weeks after rhGH treatment. 75\% Of SGA children showed an increase in weight for height after 1 year of rhGH treatment. The range of difference in weight for height varies from -0.43 SDS to 0.65 SDS. All children showed an increase in TBW. 


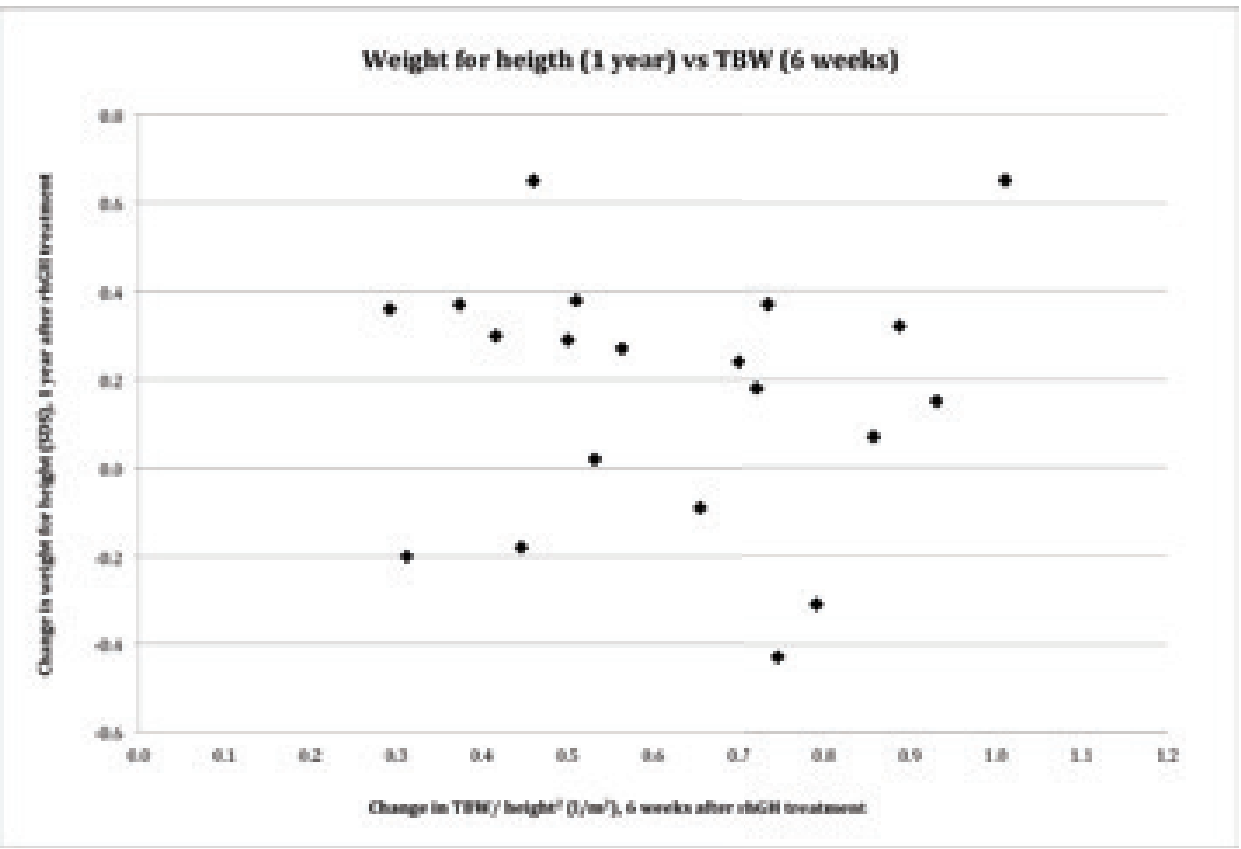

Figure 2: Change in weight for height (SDS), after 1 year of rhGH treatment, plotted against the change in TBW/ height ${ }^{2}\left(1 / \mathrm{m}^{2}\right), 6$ weeks after the start of rhGH treatment.

\section{Discussion}

The present study of 20 SGA children showed a change in TBW after six weeks of treatment with rhGH of 0.62 as well as a change in height one year thereafter of 0.81 SDS. These results are comparable with the nationwide Dutch study of Ernst et $\mathrm{al}^{15}$ of 99 SGA children where the treatment with rhGH of SGA children results in a change of the TBW with 0.68 SDS after six weeks and an increase in height, one year after rhGH treatment of 0.87 SDS.

SGA children are treated with rhGH primarily to repair their small height. At the same time monitoring of weight in relation to height is also of great importance, because SGA children are prone to increase their weight outside the normal range. This increase must be prevented to reduce the risk on the metabolic syndrome, which origin has to be found in early life, as stated on Barker's hypothesis ${ }^{21,22,23}$. Morgan et al supports the concept that genetic factors associated with obesity and/ or risk of type 2 diabetes are more prevalent in those born SGA compared to those born appropriate for gestational age (AGA) ${ }^{24}$. Meas. et al stated that being born SGA affects body composition: Adults, born SGA, show an accelerated gain in BMI and waist circumference, which in turn results in higher body fat content with a central 
distribution ${ }^{25}$. Ibanez et al showed that in SGA children a dramatic transition towards central adiposity and insulin resistance occurs between the age of two and four years ${ }^{26}$. Thereby, overweight former SGA children have an increased risk for the components of the metabolic syndrome compared with overweight former AGA children ${ }^{27}$. Thus, an increase in weight in SGA children has to be prevented at an early age.

For that reason, monitoring of weight is of great importance and especially the question "Is there an increase in fat or in fat-free mass?" must be answered according to the body composition. The change in body composition can be measured by the Deuterium method. However, this method seems to be less accurate in SGA children based on the observation that in GHD children a change is visible of 0.93 compared to SGA of 0.62 . This difference must be based on an increase in FFM more than a shift from FM to FFM because SGA children already have a body fat percentage, which is reduced before treatment ${ }^{17,18}$. Therefore, as a result of rhGH treatment, a decrease in FM can hardly be expected and mainly an increase in FFM can be measured. That means that the detected increase in weight must be based on an increase in FFM instead of FM.

Therefore not only the relation between the change in TBW and the increase in height after one year is explored in this study, but also the relation between the change in BMI and the change in weight for height. BMI and weight for height of SGA children barely changed during the first year of rhGH treatment, while the change in TBW was already evident after six weeks of treatment. The fact that the BMI did not change in contrast to weight for height can be explained by the increase in height.

In daily practice TBW measurement is not applicable, because this measurement is not easily achievable. Weight for height measurement seems to be a better measuring method to evaluate the change in body composition than BMI. BMI turns out to be higher than in children (below the age of 10 years) with a smaller height, although the child has a weight that suits its height, taking the P3, P50 and P97 values into account, as is illustrated in (Table 2). For that reason we must remark that the use of BMI must be carefully interpreted in children below the age of 10 years. 
Table 2: Height, weight and corresponding BMI values of the $3^{\text {rd }}, 50^{\text {th }}$ and $97^{\text {th }}$ percentile of a 4-year, resp. 10-year old boy.

\begin{tabular}{llll}
\hline & Height $(\mathrm{cm})$ & Ideal Weight $(\mathrm{kg})$ & BMI $\left(\mathrm{kg} / \mathrm{m}^{2}\right)$ \\
\hline Boy, 4 years & & & \\
$\mathrm{P}_{3}$ & 99 & 14.2 & 14.5 \\
$\mathrm{P}_{50}$ & 107 & 17.7 & 15.5 \\
$\mathrm{P}_{97}$ & 115 & 21.3 & 16.1 \\
Boy, 10 years & & & \\
$\mathrm{P}_{3}$ & 129 & 24.7 & 14.8 \\
$\mathrm{P}_{50}$ & 141 & 30 & 15.1 \\
$\mathrm{P}_{97}$ & 152 & 37.5 & 16.3 \\
\hline
\end{tabular}

Increase in BMI is an extra risk factor for SGA children, because if this value increases in children with a relative short length, the increase in weight is relatively higher than in children with a higher length who show a same increase in BMI.

For health care practitioners it is important to be aware that BMI, as well as weight for height values, should not change in SGA children after rhGH treatment to prevent the risk of developing the metabolic syndrome. According to the results of this study, it is reasonable to use cut-off values; a difference in BMI of +/- 1.0 and an increase or decrease of 0.4 SDS in weight for height is acceptable.

\section{Conclusion}

During the first year of rhGH treatment, the BMI and weight for height of SGA children barely change. The detected slight increase in TBW in SGA children is based on an increase in FFM and not in FM. This means that the body composition in SGA children improves after receiving rhGH treatment. This treatment contributes in the prevention of the metabolic syndrome in SGA children. For health care practitioners it is important to monitor that BMI, as well as weight for height values should not change in SGA children, after rhGH treatment. 


\section{References}

1. Battaglia FC, Lubchencko LO. A practical classification of newborn infants by weight and gestational age. J Pediatr 1967; 71:159.

2. Ong KK, Ahmed ML, et al. Association between postnatal catch-up growth and obesity in childhood: Prospective cohort study. BMJ 2000; 320:967-971.

3. Forsen T, Eriksson J, et al. The fetal and childhood growth of persons who develop type 2 diabetes. Ann Intern Med 2000; 33:176-182.

4. Baird J, Fisher D,et al. Being big or growing fast: Systematic review of size and growth in infancy and later obesity. BMJ 2005; 331:929.

5. Barker DJ, Winter PD, et al. Weight in infancy and death from ischaemic heart disease. Lancet 1989; 2:577-580.

6. Ong K, Ahmed ML,et al. Association between postnatal catch-up growth and obesity in childhood: Prospective cohort study. BMJ 2000; 320:967-71.

7. Health council of the Netherlands committee of growth hormone. Use of growth hormone. The Hague: Council of the Netherlands; 1995.

8. Zegher F, Hokken-Koelega A. Growth Hormone therapy for children small for gestational age: Height gain is less dose dependant over the long term than over the short term. Pediatrics 2005; 115:E458 doi:10.1542/PEDS. 2004-1934.

9. Hassan HM, Kohno H,et al. Body composition, atherogenic risk factors and apolipoproteins following growth hormone treatment. Acta Paediatr 1996; 85:899-901.

10. Cowan FJ, Evas WD, et al. Metabolic effects of discontinuing growth hormone treatment. Arch Dis Child 1999; 80:517-523.

11. Gregory JW, Greene SA, et al. Changes in body composition and energy expenditure after six weeks' growth hormone treatment. Arch Dis Child 1991; 66:598-602.

12. Dempsher DP, Bier DM, et al. Whole body nitrogen kinetics and their relationship to growth in short children treated with recombinant human growth hormone. Pediatr Res 1990; 28:394-400.

13. Leger J, Garel C, et al. Human growth hormone treatment of short-stature children born for gestational age: effect on muscle and adipose tissue mass during a 3-year treatment period and after 1 year's withdrawal. J Clin Endocrinol Metab 1998; 83:3512-3516.

14. Hoos MB, Westerterp KR, et al. Short -term effects of growth hormone on body composition as a predictor of growth. J Clin Endocrinol Metab 2003; 88(6):2569-2572.

15. Ernst MAB, Simons MYG, et al. Change in body composition as a predictive tool for growth hormone treatment in growth hormone deficient children and children born small for gestational age. Hormone Research in Paediatrics 2012; 78(1):18-23.

16. Lapillonne A, Braillon $\mathrm{P}$, et al. Body composition in appropriate and in small for gestational age infants. Acta Paediatr 1997; 86(2):196-200.

17. Willemsen RH, Arends NJT, et al. Long-term effects of growth hormone (GH) treatment on body composition and bone mineral density in short children born small-for-gestational-age: six year follow-up of a randomized controlled GH trial. Clinical Endocrinology 2007; 67:485-492.

18. de Zegher F, Francois L, et al. Growth hormone treatment of short children born small for gestational age. Trends Endocrin Metab 1998; 9(6):233-237.

19. Gerver WJM, De Bruin R. Paediatric Morphometrics, A reference manual. (second extended edition). University Press Maastricht, The Netherlands, ISBN 905278307 1; 2001.

20. Westerterp KR, Wouters L, et al. The Maastricht protocol for the measurement of body composition and energy expenditure with labeled water. Obes Res 1995; 3:49-57.

21. Barker DJ, Osmond C, et al. Trajectories of growth among children who have coronary events as adults. N Engl J Med 2005; 353(17):1802-9.

22. Barker DJ. Obesity and early life. Obes Rev 2007; 8 Suppl 1:45-9.

23. Singhal A, Lucas A. Early origins of cardiovascular disease: is there a unifying hypothesis? Lancet 2004; 363(9421):1642-5. 
24. Morgan AR, Thompson JMD, et al. Obesity and diabetes genes are associated with being born small for gestational age: Results from the Auckland Birthweight Collaborative study. BMC Medical Genetics $2010 ; 11: 125$.

25. Meas T, Deghmoun S, et al. Consequences of being small for gestational age on body composition: An 8-year follow up study. J Clin Endocrinol Metab 2008; 93(10):3804-09.

26. Ibanez L, Ong K, et al. Early development of adiposity and insuline resistance after catch-up weight gain in small-for-gestational-age children. J Clin Endocrinol Metab 2006; 91(6): 2153-2158.

27. Reinehr T, Kleber M, et al. Small for gestational age status is associated with metabolic syndrome in overweight children. Eur J Endocrinol 2009; 160:579-584. 
BODY PROPORTIONS IN SMALL FOR GESTATIONAL AGE CHILDREN AFTER RECEIVING GROWTH HORMONE TREATMENT 



\section{CHAPTER 5}

A PREDICTION MODEL TO PREVENT ABNORMAL WEIGHT IN CHILDHOOD

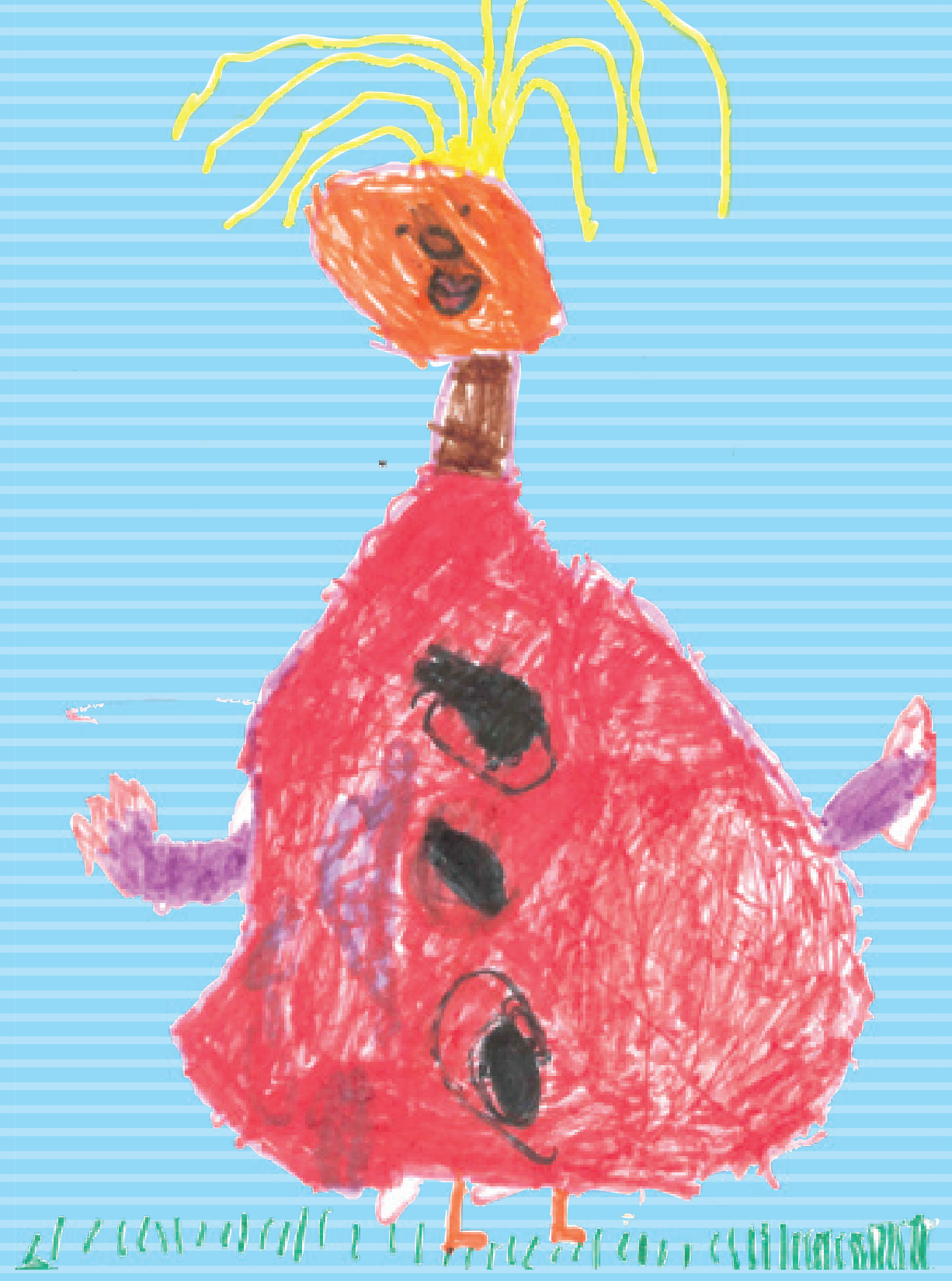


CHAPTER 5 


\section{CHAPTER 5}

\section{A prediction model to prevent abnormal weight in childhood}

The concern about obesity in childhood is based on the hypothesis, that it leads to obesity in adulthood and is thereby a risk for developing the metabolic syndrome. The question arises whether or not it is possible to detect at an early age, those children who are at risk for developing obesity and to create a prediction model to prevent abnormal weight. For that reason, the data from the Dutch longitudinal growth study, collected in 1995-1999, by Gerver et al, were used to estimate the change in Ponderal Index (PI) and Body Mass Index (BMI) during the first four years of life. It became clear that the PI during the first year, as well as the BMI from the age of 1 year onwards, is changing for most children, dependent on their starting value. This phenomenon can be partly ascribed to the regression to the mean.

A prediction model was developed to estimate the growth pattern of infants. Based on the individual growth patterns, we could estimate a $\mathrm{PI}$ or BMI after a certain period of growth by using formulas representing the "normal" growth of a child. If the actual growth pattern of an individual child does not fit into the expected growth pattern, intervention may be needed to prevent obesity later on and thereby reduce the risk of the metabolic syndrome. This prediction model could be used by the youth health care preventing obesity in childhood.

This chapter is submitted for publication by:

Manon AB Ernst, Huub MH Creemers, Maria WJ Jansen, Angèle JGM Gerver, Luc JI Zimmermann and Willem JM Gerver 
CHAPTER 5 


\section{Introduction}

There is a rising concern about the worldwide increase of obesity in children ${ }^{1,2,3}$. Studies during the 1990s show that in Brazil and the USA, an additional 0.5\% of the entire child population became overweight each year. In Canada, Australia and parts of Europe the rates were higher, with an additional 1\% of all children becoming overweight each year ${ }^{4}$. Also for the Netherlands this tendency prevails and many local, as well as national health programs are focused on reducing this incidence. The concern about obesity in childhood is based on the observation, that overweight in childhood leads to obesity in adulthood and thereby to a risk to the metabolic syndrome characterized by insulin resistance, dyslipidemia, elevated blood pressure and cardiovascular diseases $5,6,7,8$. The idea that the origin of the metabolic syndrome has to be found in early life is based on Barker's hypothesis, that malnutrition in utero brings about a permanent change in the metabolism $^{9,10,11,12}$. According to the statement of Barker, it is generally accepted that small for gestational age (SGA) children are prone to develop the metabolic syndrome in adulthood. Also obesity in children is rising among the urban poor in developed nations, possibly due to their exposure to Westernized diets coinciding with a history of undernutrition ${ }^{4}$. This "fetal origin hypothesis" made the youth health care physician and pediatrician involved in this problem. Health professionals, who provide primary care for children, are in the center of the pediatric obesity epidemic and can play a pivotal role in early detection of obesity.

Cole et al provided cut off points for Body Mass Index (BMI) in childhood ${ }^{13}$, whereby overweight and obesity in children can be determined. Those cut off points can tell us, if a child suffers from overweight or obesity at that moment. Once overweight or obesity is manifested, it is very difficult to solve the problem. Therefore, the question arises whether or not it is possible to detect those children, who are at risk to develop overweight already at an early age, before overweight or obesity has been established, in order to make prevention of abnormal weight increase possible. For that reason we constructed a prediction model, based on the longitudinal data of healthy infants, followed from birth until the age of 4 years. This study is performed in the South of the Netherlands from 1995-199914. Such a model can provide the possibility to discover, whether the growth of an individual child still fits within the expected range of the growth velocity and thereby to detect if a child risks an abnormal growth. Obesity prevention might then be possible already during the first years of life in the regular preventive health care program, coordinated by the youth health care providers. Screening tools for deviated growth and body proportions are essential in a preventive program and can be used in the follow up of children. 
The aim of this study is to construct a prediction model for abnormal growth in childhood that can be used from birth to the age of four years.

\section{Methods}

\section{Sample}

Data for this growth study were collected in the South of the Netherlands, in Maastricht and near surroundings. Infants were measured from 1995 until 1999 in a longitudinal growth stud ${ }^{14}$. The study population consisted of 1234 full-term nonhospitalized infants, whose parents were both of Caucasian origin and whose health and living circumstances such that neither in the past nor during the study, growth retardation should be expected. Infants were measured, during their regular visits at the Maastricht infant health-care centers. The parents were informed about the purpose of the study and their permission and cooperation were requested. The medical ethics committee approved the study.

To acquire reliable longitudinal growth curves only those children were included with at least 9 measurements: 6 during the first year of life and three measurements with at least 1 measurement a year during the following 3 years. Based on these criteria 372 (30.1\%) children out of 1234 could be included in this study.

\section{Measurements}

Length was measured with the Harpenden infantometer in supine position. From the age of 2 years, standing height was measured with a portable stadiometer. Measurements were taken according to the international accepted methods described before ${ }^{14}$. Weight was measured using an electronic scale accurate to 1 gram. All measurements were taken by one trained person (A.J.G.M.G.).

Based on weight and height the Ponderal Index (PI) and BMI, besides the measurements of weight and height, were used to construct a prediction model

For each of the 372 children, weight in relation to height is expressed as the PI for infants up to 1 year of age and the BMI thereafter. The Ponderal Index is an adequate measure for individuals with a deviating stature; therefore it is more appropriate for very young children ${ }^{15}$.

The PI is defined as:

$$
\text { PI }=100 \times \frac{\text { weight }_{g r}}{\text { height }_{c m}^{3}} 16
$$

The BMI is defined as: 


$$
\mathrm{BMI}=\frac{\text { weight }_{\mathrm{kg}}}{\operatorname{height}_{m}^{2}}
$$

Of each child the PI and BMI were plotted against age and a regression line $(y=\alpha t+$ c) was drawn representing the individual change of growth in time (Figure 1). The slope of the regression line, expressed as the individual alpha PI ( $\alpha_{P I}$ ind $)$ or alpha BMI ( $\left.\alpha_{\text {BMI ind }}\right)$, estimates the growth velocity of the child while the constant value of $c$ indicates the PI or BMI at $t_{0}$. Thus $\alpha_{P I}$ ind represents the growth velocity from birth until the age of 1 year, $\alpha_{\mathrm{BMI}}$ ind represents the growth velocity from the age of 1 year until the age of 4 years.

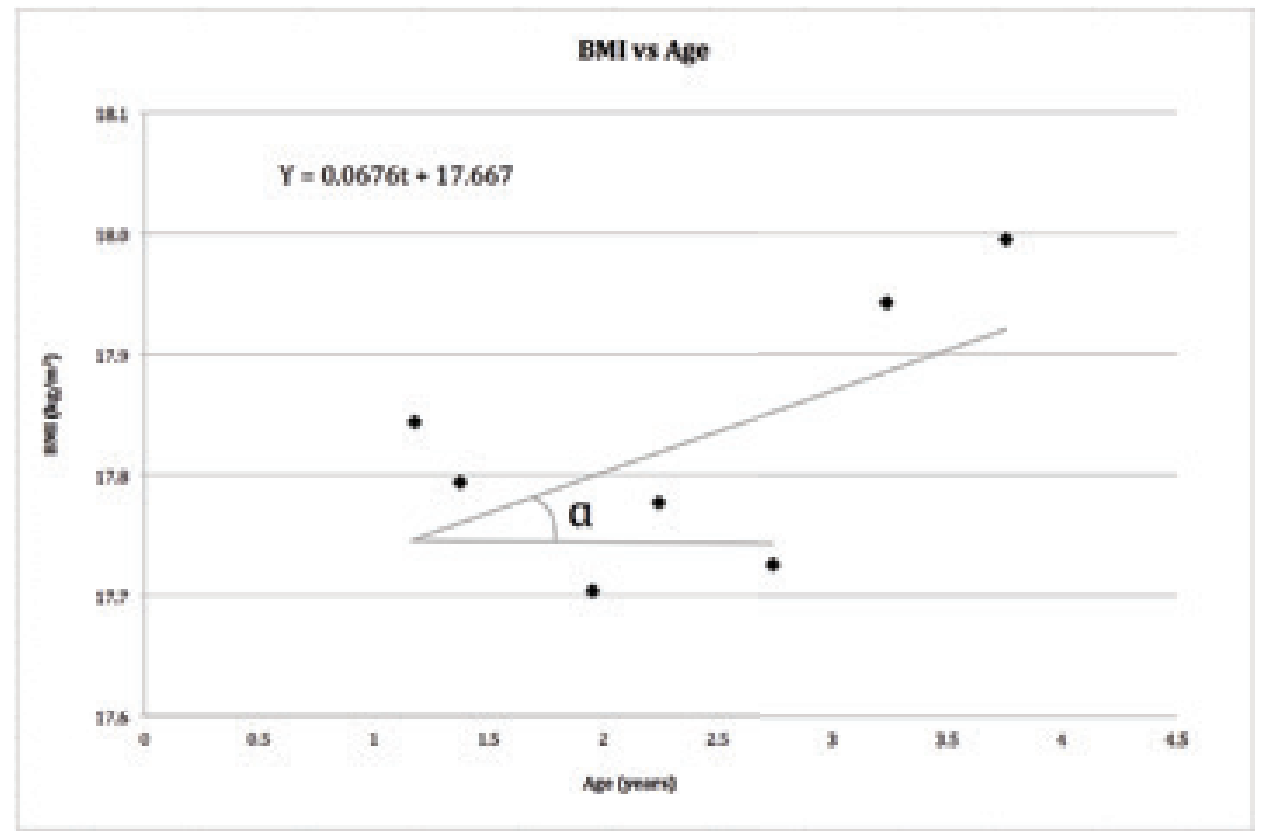

Figure 1: Example of an individual child; the individual BMI is plotted against age.

The value of $\alpha_{P I}$ ind or $\alpha_{B M I}$ ind depends on the PI or BMI at $t_{0}$, this means that a high value of PI or BMI at $t_{0}$ will result in a lower $\alpha$ and a low value of PI or BMI at $t_{0}$ in a higher $\alpha$. This phenomenon is known as the regression to the mean ${ }^{17}$.

Next, all $\alpha_{P I}$ ind and all $\alpha_{B M I}$ ind values were plotted against all individual values of PI at birth and BMI at the age of 1 year respectively. Regression lines were calculated, based on the corresponding $\alpha$ values, representing the total child population ( $\alpha$ tot). The expected value of the PI $\left(\mathrm{PI}_{\mathrm{e}}\right)$ and $\mathrm{BMI}\left(\mathrm{BMI}_{\mathrm{e}}\right)$ at a certain age can be estimated according to the formulas: 
$\mathrm{PI}_{\mathrm{e}}=(\mathrm{ax}+\mathrm{b}) * \mathrm{t}+\mathrm{x}$

Where $\mathrm{ax}+\mathrm{b}=\alpha_{\text {PI tot }} \mathrm{x}=\mathrm{PI}$ at birth and $\mathrm{t}=$ the decimal age, $0<\mathrm{t} \leq 1$

$\mathrm{BMI}_{\mathrm{e}}=(\mathrm{ax}+\mathrm{b}) * \mathrm{t}+\mathrm{x}$

Where $\mathrm{ax}+\mathrm{b}=\alpha_{\mathrm{BMI}}$ tot, $\mathrm{x}=\mathrm{BMI}$ at the age of 1 year and $\mathrm{t}=$ the decimal age, $1<\mathrm{t} \leq 4$

Finally, for each individual the measured PI and BMI were subtracted from the expected PI or BMI at the same age to verify the validity of our model.

\section{Results}

In Figure 2, the linear regression line, based on the total child population, is drawn representing $\alpha_{\text {PI tot }}=-0.6353 \mathrm{x}+1.2887$, where $\mathrm{x}$ is PI at birth. $\alpha_{\mathrm{PI}}$ tot Represents the mean change in PI of the population from birth until the age of 1 year.

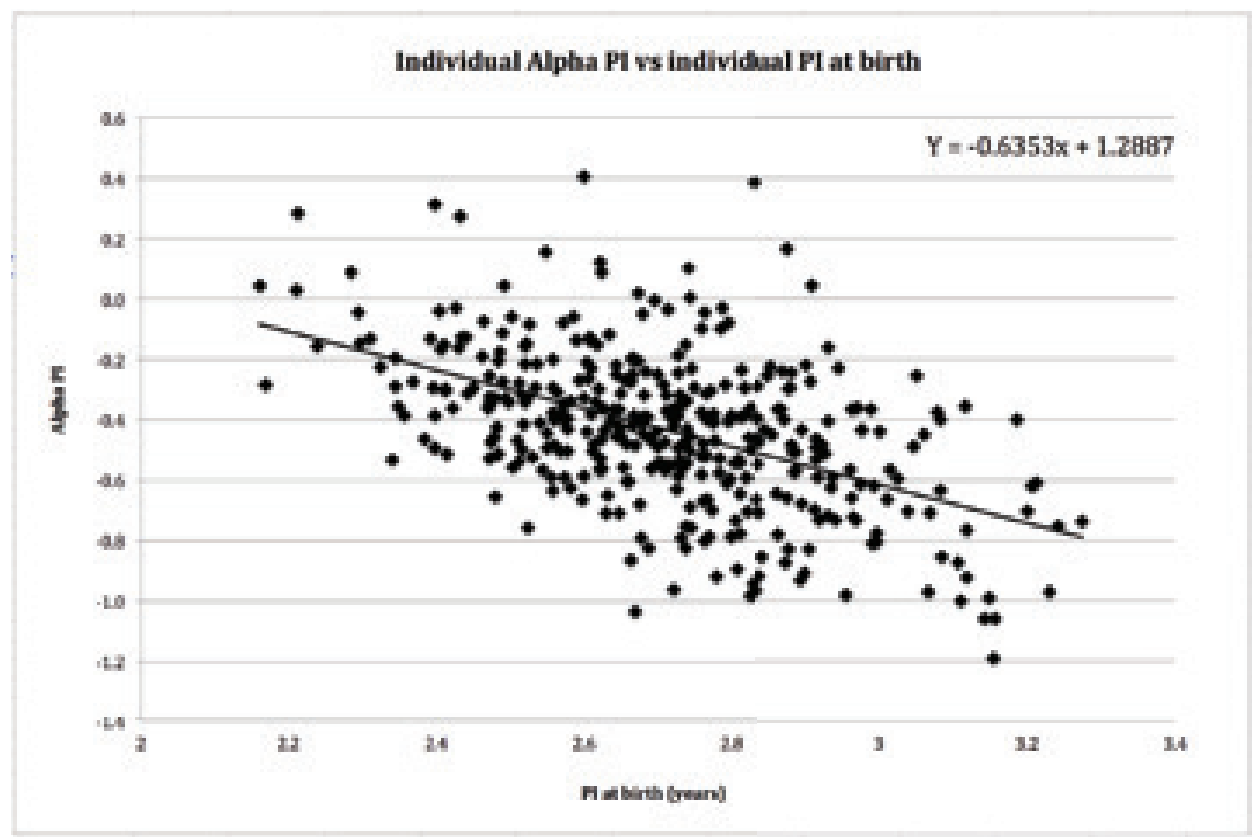

Figure 2: Individual $\alpha_{P I}$ plotted against individual PI at birth $(n=372)$.

In the same way all individual $\alpha_{\text {BMI }}$ values were plotted against all individual BMI values at the age of 1 year. For BMI the regression line, based on the total child population, revealed to be: $\alpha_{\mathrm{BMI}}$ tot $=-0.1818 \mathrm{x}+2.7189$, where $\mathrm{x}=\mathrm{BMI}$ at the age of 1 year. 
$\alpha_{\mathrm{BMI}}$ tot Represents the mean change in BMI of the population from the age of 1 year until the age of 4 years. Based on these $\alpha$ tot values the expected value of the PI or BMI at a certain age for an individual child can be calculated according to the formulas:

$P I_{e}=(-0.64 x+1.29) * t+x$

Where $-0.64 \mathrm{x}+1.29=\alpha_{\mathrm{PI}}$ tot, $\mathrm{x}=\mathrm{PI}$ at birth and $\mathrm{t}=$ the decimal age, $0<\mathrm{t} \leq 1$

$\mathrm{BMI}_{\mathrm{e}}=(-0.18 \mathrm{x}+2.72) * \mathrm{t}+\mathrm{x}$

Where $-0.18 \mathrm{x}+2.72=\alpha_{\mathrm{BMI}}$ tot, $\mathrm{x}=\mathrm{BMI}$ at the age of 1 year and $\mathrm{t}=$ the decimal age, $1<\mathrm{t} \leq 4$

The mean expected PI of all measurements is: 2.28 (with a standard deviation (SD) of 0.075 ) at the age of 1 year. The mean expected BMI of all measurements is: 15.50 (SD: 0.436$)$ at the age of 4 years.

For example, a child with a birth weight of $4 \mathrm{~kg}$ and a birth length of $51 \mathrm{~cm}$, has a corresponding PI at birth of 3 . According to the formula, it is to be expected that this infant will have a PI at the age of 1 year of $2.37((-0.64 * 3+1.29) * 1+3=$ 2.37). With a given SD of 0.075 the range of expectation of the PI with a confidence interval of $2 \mathrm{SD}$ is between 2.22 and 2.52. In the same way the BMI at the age of 4 years can be estimated by knowing the BMI at the age of 1 year. For example, a child with a weight at the age of 1 year of $9 \mathrm{~kg}$ and a length of $75 \mathrm{~cm}$ has a corresponding BMI at the age of 1 year of 16 . According to the formula, it is to be expected that this child will have a BMI of 15.36 at the age of 4 years $((-0.18 * 16+$ $2.72) * 4+16=15.36$ ). With given SD of 0.436 the range of expectation of the BMI with a confidence interval of 2 SD is from 14.49 to 16.23 .

The mean difference between the measured and expected PI values at the age of 1 year is -0.002 ( $S D=0.22$ ). The mean difference between the measured and expected $\mathrm{BMI}$ values at the age of 4 years is $0.003(\mathrm{SD}=1.35)$.

In Figure 3, the difference between the measured PI value and the estimated PI value at the age of 1 year is plotted against the PI at birth (as calculated above). In Figure 4, the difference between the measured BMI value and the estimated BMI value at the age of 4 years is plotted against the BMI at the age of 1 year (as calculated above). 


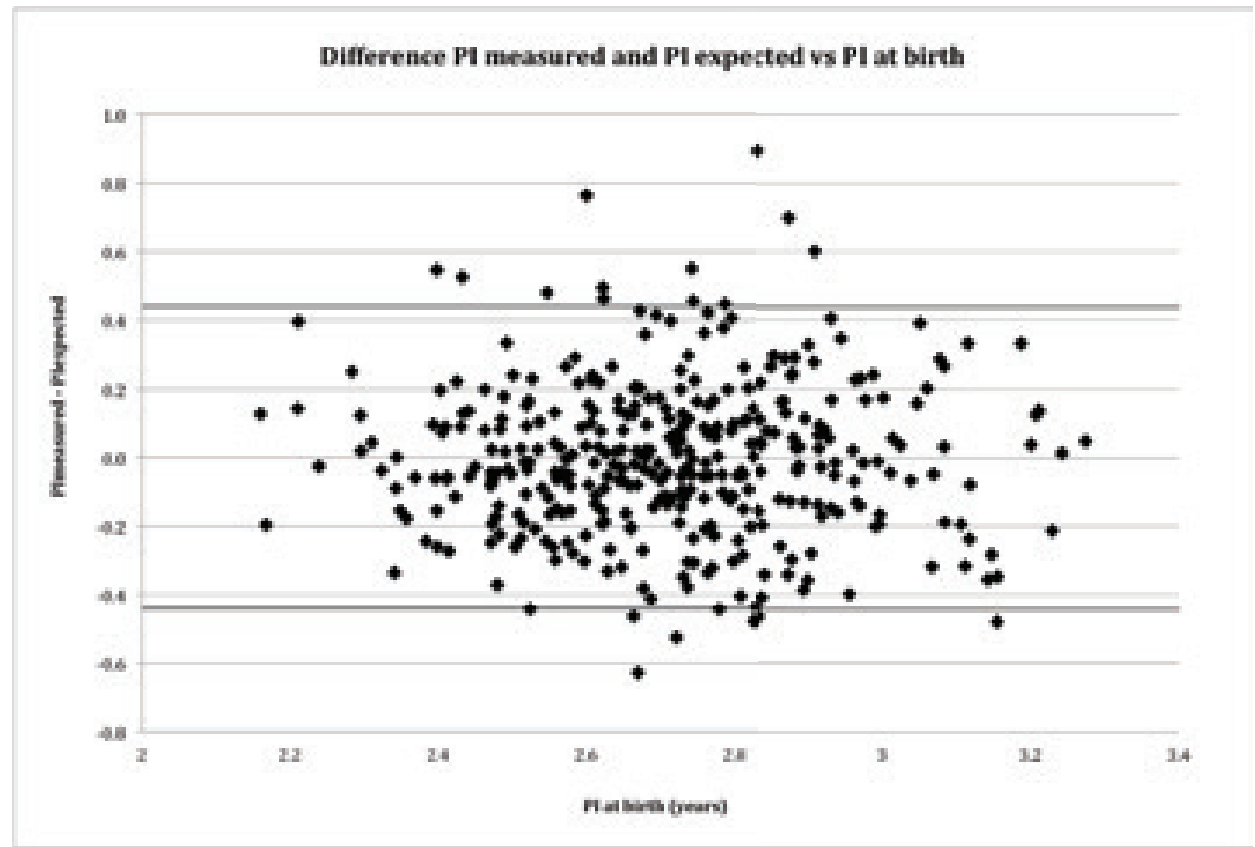

Figure 3: The difference of the measured and expected PI at the age of 1 year is plotted against the PI at birth. The -2SD and + 2SD limits are shown.

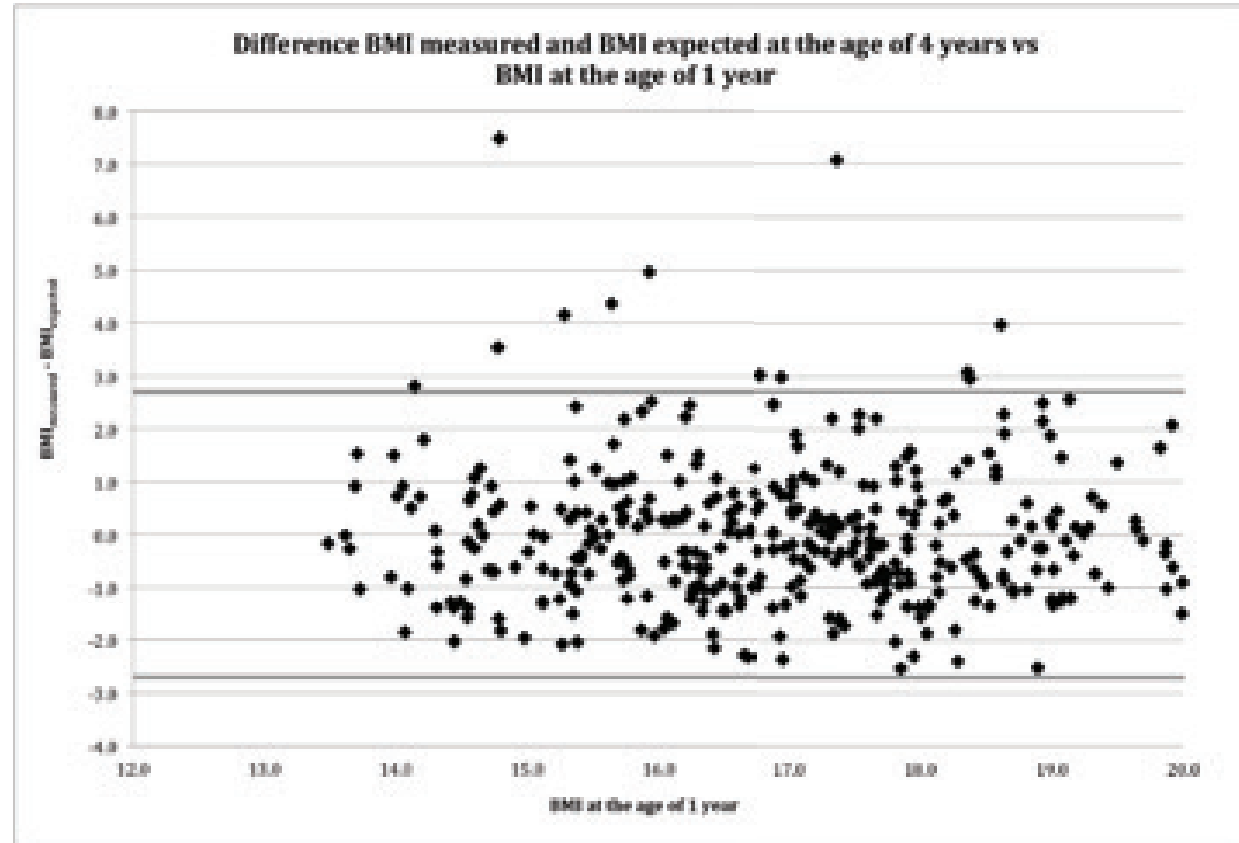

Figure 4: The difference of the measured and expected BMI at the age of 4 years is plotted against the BMI at the age of 1 year. The -2SD and + 2SD limits are shown. 


\section{Discussion}

The longitudinal growth study from 1995-1999 $(n=1234)$ in the South of the Netherlands ${ }^{17}$ made it possible not only to construct velocity curves for the total child population, but also to analyze the individual growth patterns during a certain period of life. Depending on its starting position, a child tends to decelerate or accelerate its growth velocity. This is known as the regression to the mean. Based on the individual growth patterns, we could estimate a PI or BMI after a certain period of growth. If the measured value is $>2$ SD above the expected value, the child runs the risk of developing obesity. These are the children with an unexpected change of body composition and possibly at risk for an abnormal metabolic development. If the measured value is $<2$ SD below the expected value, the child runs the risk of developing underweight or may be suffering from gastrointestinal problems like celiac disease.

By means of the mentioned method, for each of the 372 children the prediction model was applied at birth to estimate the PI at any age between birth and the age of one year and applied at the age of one year to estimate the BMI at any age between one and four years.

To estimate the accuracy of the prediction model the differences between the actual PI or BMI at the age of 1 year and 4 years respectively and the expected values at both ages were taken. The results for PI and BMI show that the majority $(95.2 \%$ and $96.8 \%$ respectively) of the values fit within 2 SD, as shown in Figure 3 and Figure 4. This supports the internal validity, which means that the prediction model works correctly for our study population and research artifacts can be excluded.

The value of this prediction model is, that it gives the possibility to estimate if a child tends to deviate from its personal expected PI or BMI value already at a moment at which the PI or BMI is still normal. In other words, although a child still has a normal weight in relation to its height, its growth pattern indicates the development of under- or overweight and needs to be investigated to prevent abnormal growth. At the moment, by calculation of BMI, health care physicians can determine if a child suffers from overweight or underweight. For example in case of overweight, parents can be counseled, mostly directed to life style behaviors. By using our prediction model, parents can be warned before the problem has been established.

If this prediction model can be integrated in the electronic child record, this can be an important step forward in the prevention of abnormal growth, like obesity. By adding the age and starting values of length and weight (values at birth for PI prediction and values at the age of 1 year for BMI prediction) of a child into the formu- 
las, runs the risk of developing an abnormal growth can be calculated in a quick and easy way.

Early detection that can help to reverse the increase in overweight and obesity incidence is urgently needed. Excess body weight is a major public health concern worldwide $^{18}$. The costs to health services, the losses to society and the burdens carried by the individuals involved are great ${ }^{4}$. It seems beneficial if the youth health care providers would use this prediction model in their health care program to prevent abnormal growth in childhood.

\section{Conclusion}

This study adds a new method of considering the growth of children. Our research has shown that it is possible to create prediction models for early prevention of abnormal growth, by using longitudinal data.

The model can easily be used in the health care practice by adding data of age, weight and length in the electronic child record. A digital implementation calculates if a child runs the risk of developing an abnormal growth. In this case, an alarm signal (e.g. a red colour in case of obesity and a yellow colour in case of underweight) will appear on the computer screen.

Collecting anthropometric data from electronic child records from birth onwards can make it possible to update prediction models in the future.

\section{Acknowledgement}

This study has been supported by a grant of the Netherlands Organisation for Health Research and Development, ZonMw, to develop the Academic Collaborative Centre for Public Health Limburg (projectnumber 7125.0001). 


\section{References}

1. Seidell JC. Obesity in Europe: scaling an epidemic. Int J Obes Relat Metab Disord 1995; 19 Suppl 3:S14.

2. Hirasing RA, Fredriks AM, et al. Increased prevalence of overweight and obesity in Dutch children, and the detection of overweight and obesity using international criteria and new reference diagrams. Ned Tijdschr Geneeskd 2001; 145:1303-8.

3. Rossner S. Obesity: The disease of the twenty-first century. Int J Obes 2002; 26 Suppl 4:S2-4.

4. Lobstein T, Baur L,et al. Obesity in children and young people: A crisis in public health. Obes rev 2004; 5 (Suppl. 1):4-85.

5. Weiss R, Dziura J, et al. Obesity and the metabolic syndrome in children and adolescents. N Eng J Med 2004; 350:2362-74.

6. Liese AD, Mayer-Davis EJ, et al. Development of the multiple metabolic syndrome: an epidemiologic perspective. Epidemiol Rev 1998; 20(2):157-72.

7. Lakka HM, Salonen JT, et al. Obesity and weight gain are associated with increased incidence of hyperinsulinemia in non-diabetic men. Horm Metab Res 2002; 34(9):492-8.

8. Lorenzo C, Serrano-Rios M, et al. Central adiposity determines prevalence differences of the metabolic syndrome. Obes Res 2003; 11(12):1480-7.

9. Barker DJ, Winter PD, et al. Weight in infancy and death from ischaemic heart disease. Lancet 1989; 2(8663):577-80.

10. Barker DJ, Osmond C, et al. Trajectories of growth among children who have coronary events as adults. N Engl J Med 2005; 353(17):1802-9.

11. Barker DJ. Obesity and early life. Obes Rev 2007; 8 Suppl 1:45-9.

12. Singhal A, Lucas A. Early origins of cardiovascular disease: is there a unifying hypothesis? Lancet 2004; 363(9421):1642-5.

13. Cole TJ, Bellizzi MC, et al. Establishing a standard definition for child overweight and obesity worldwide: international survey. BMJ 2000; 320(7244):1240-3.

14. Gerver WJM. de Bruin R. Paediatric Morphometrics, A reference manual. (second extended edition). University Press Maastricht, The Netherlands, ISBN 905278307 1; 2001.

15. Gunther B. Dimensional analysis and theory of biological similarity. Physiol. Rev 1975; 55(4):65999.

16. Rohrer F. Der Index der Korperfulle als Mass des Ernahrungszustandes. Muncher Med Wrsch 1921; 68:580-82.

17. Barnett AG, van der Pols JC, et al. Regression to the mean: What it is and how to deal with it. Int J Epidemiol 2005; 34:215-20.

18. Finucane MM, Stevens GA, et al. National, regional and global trends in body mass index since 1980: Systematic analysis of health examination surveys and epidemiological studies with 960 country years and 9.1 million participants. Lancet 2011; vol. 377:557-567. 



\section{CHAPTER 6}

THE USE OF A PREDICTION MODEL TO

PREVENT ABNORMAL WEIGHT IN CHILDHOOD IN THE YOUTH HEALTH CARE PRACTICE

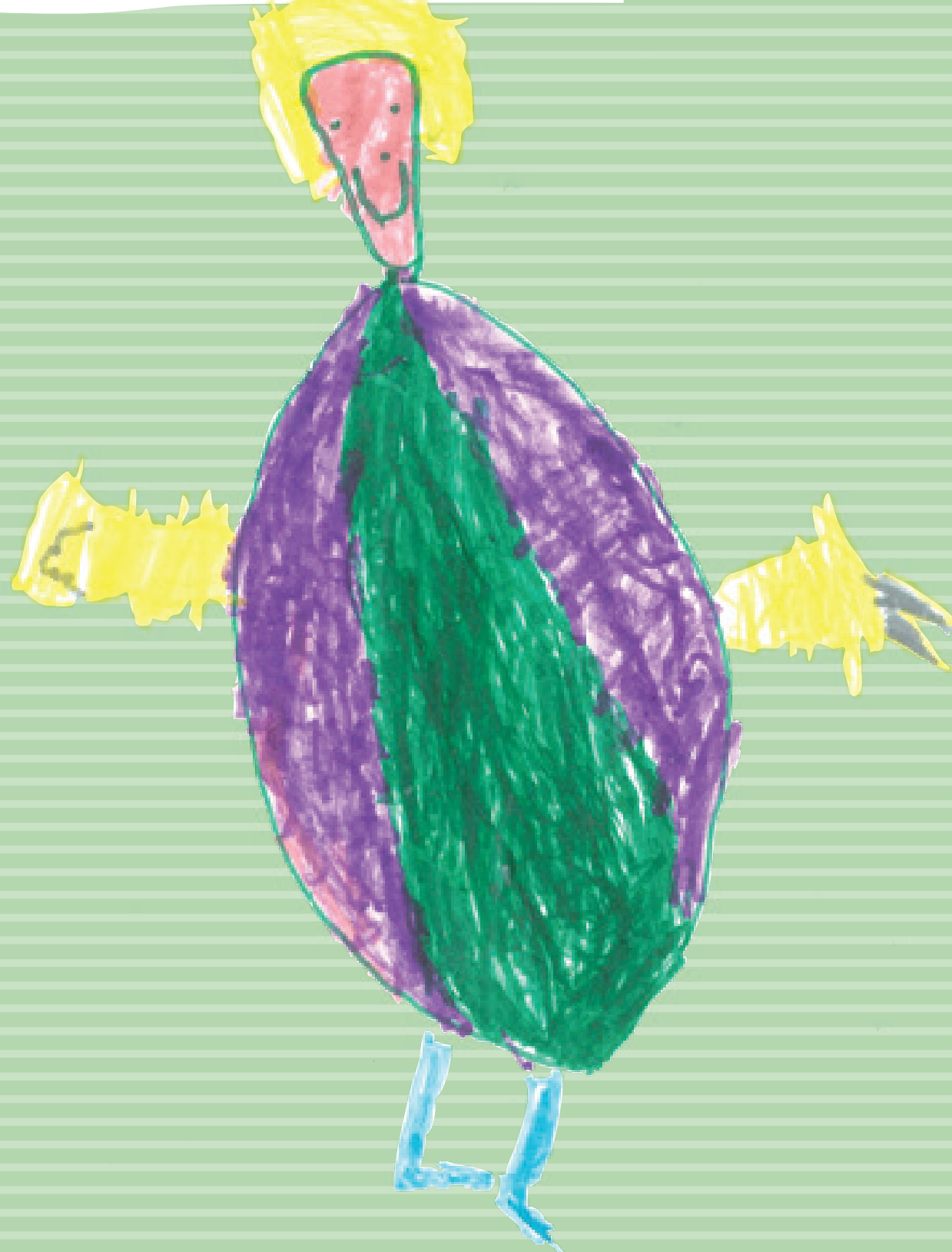


CHAPTER 6 


\section{CHAPTER 6}

\section{The use of a prediction model to prevent abnormal weight in childhood in the Youth Health Care Practice}

Obesity in childhood is an increasing health problem and once it has been established, it becomes very difficult to solve this problem.

Accordingly, we created a prediction model to detect the tendency of becoming overweight in childhood at a moment overweight has not been established yet.

Data for this study were retrospectively collected at the youth health care department of the Regional Public Health Service South Limburg, Maastricht. Child records of 120 children, born in 2002, who developed overweight at the age of 5 years, were collected. As a control group, we also collected data of 120 children, born in 2002, in the same region, who did not develop overweight or obesity at the age of 5 years. Based on longitudinal data, the expected value of the Ponderal Index $\left(\mathrm{PI}_{\mathrm{e}}\right)$ at a certain age $(\mathrm{t})$ until the age of 1 year, depending on the child's starting position at birth was calculated. According to our hypothesis, a child is at risk for overweight at the age of 5 years, if the measured $\mathrm{PI}$ value $\left(\mathrm{PI}_{\mathrm{m}}\right)>\mathrm{PI}_{\mathrm{e}}+2 \mathrm{SD}$. We applied the prediction model to the overweight and non overweight group to test our hypothesis.

We compared our prediction model with 2 other methods to estimate (ab)normal growth of children;

The often used weight for length growth chart and The PI calculation.

Out of those 3 methods, our prediction model appears to be the best predictor for overweight at the age of 5 years.

By using this prediction model, we are able to estimate the growth pattern of an infant. If the actual growth pattern of the infant does not fit into the expected growth, intervention may be needed to prevent abnormal growth. By implementing the prediction model in the electronic child record, health care practitioners could use this model in preventing overweight in children at an early age.

This chapter is submitted for publication by:

Manon AB Ernst, Michelle YG Simons, Maria WJ Jansen, Luc JI Zimmermann and Willem JM Gerver. 
CHAPTER 6 


\section{Introduction}

Obesity in childhood is one of the most challenging diseases to tackle these days. Nowadays it has reached epidemic levels. In 2010, around 43 million children under 5 were overweight and obese. The worldwide prevalence of childhood overweight and obesity increased from $4.2 \%$ in 1990 to $6.7 \%$ in 2010 . This trend is expected to reach $9.1 \%$ in $2020^{1}$.

Once obesity has been established, it becomes very difficult to solve this problem. Therefore it is of great importance to develop an instrument to detect the risk of becoming overweight at an early age, before overweight is evident in a child. Especially in children overweight has to be prevented, because overweight and its comorbidities will be one of the biggest health care problems and costs in the future. Overweight and obesity are the fifth leading risk for global deaths. In addition, 44\% of the diabetes burden, $23 \%$ of the ischemic heart disease burden and between $7 \%$ and $41 \%$ of certain cancer burdens are attributable to overweight and obesity ${ }^{1}$.

Overweight and obesity in childhood and adolescence are associated with increased risk of both premature mortality and adult morbidity, particularly cardio metabolic morbidity $^{2}$. There are not only severe medical consequences of overweight in childhood; psychosocial problems are probably more prevalent. Childhood overweight has significant impact on the emotional development of the child and adolescent, like suffering from discrimination and stigmatization ${ }^{3}$. Those children are more prone to be bullied too ${ }^{4}$. Also the socioeconomic consequences of obesity should not be neglected; Persistent obesity in adulthood in women is associated with poorer employment and relationship ${ }^{5}$.

Nowadays, lots of preventing programs for overweight are developed. Most of these programs are focused on healthy food and drinks, stimulating exercise / physical activity and demoralize inactive living. Most prevention programs are applicable from the age of approximately 2 years. Growth charts are used, internationally, to detect abnormal growth of children. But these charts appear to be inadequate in preventing overweight in children at an early age. Therefore, we created a prediction model to detect the tendency of becoming overweight in childhood at a moment overweight has not been established, meant for use in early childhood, in the first year of life.

\section{Methods}

Data for this study were retrospectively collected at the youth health care department of the Regional Public Health Service South Limburg, Maastricht, the Nether- 
lands. All child records of children, born in 2002, who developed overweight at the age of 5 years, were collected. Those children were examined by a youth health care physician at the age of 5 years, in 2007. During this examination, the presence of overweight or obesity was determined, according to Dutch cut-off points for the Body Mass Index (BMI) in children defined by Hirasing et $\mathrm{al}^{6}$.

We collected all growth data of these children, from birth until the age of 5 years. Data of length, weight, gender and gestational age at birth were collected. The total amount of children included is 120 for the group of children with overweight or obesity at the age of 5 years (overweight group). As a control group, we also collected data of 120 children, born in 2002, in the same region, who did not develop overweight or obesity at the age of 5 years. Those children were selected at random.

Because the exact values of birth weight and birth length are needed to use the prediction model for the Ponderal Index (PI), children whose birth length was not known were excluded. Regarding this, the total amount of children in the overweight group is 109 and in the control group 111 . Because not every child is measured at the exact moment of 1 year, the range of time that is used is: 0.9-1.2 year for the measurements of 1 year.

We already constructed a prediction model for abnormal growth based on longitudinal data of a reference population, consisted of 372 infants, measured from 19951999 in a longitudinal growth study, in the South of the Netherlands ${ }^{7}$. In this model the prediction is based on the calculation of the PI.

The PI is defined as:

$$
\text { PI }=100 \times \frac{\text { weight }_{g r}}{\text { height }_{c m}^{3}}
$$

The PI yields valid results even for very short and very tall person ${ }^{9}$. Because of this property, it is most commonly used in pediatric ${ }^{10}$.

In our prediction model, the individual growth of a child was analyzed. For every child PI values were plotted against age, until the age of 1 year. By using regression analysis the individual $\alpha$ ( $\alpha_{\text {PI ind }}$ ) was calculated, representing the individual change of growth of a child. Next, all $\alpha_{P I}$ ind values were plotted against all individual values of PI at birth. The regression line was calculated again. Based on the new corresponding $\alpha$ values, representing the total child population $\left(\alpha_{P I}\right.$ tot $)$, the expected value of the PI $\left(\mathrm{PI}_{\mathrm{e}}\right)$ at a certain age $(\mathrm{t})$ can be estimated, depending on the child's starting position, according to the formula:

$\mathrm{PI}_{\mathrm{e}}=(\mathrm{ax}+\mathrm{b}) * \mathrm{t}+\mathrm{x}$ 
Where $\mathrm{ax}+\mathrm{b}=\alpha_{\mathrm{PI} \text { tot }} \mathrm{x}=\mathrm{PI}$ at birth and $\mathrm{t}=$ the decimal age, $0<\mathrm{t} \leq 1$.

The mean expected PI of all measurements was: 2.28 (with a standard deviation (SD) of 0.075 ) at the age of 1 year.

We applied our prediction model on the birth cohort of 2002 by using the prediction model for abnormal growth. Thereby, the measured PI value $\left(\mathrm{PI}_{\mathrm{m}}\right)$, the $\mathrm{PI}_{\mathrm{e}}$ value and their difference were calculated for every individual child. We examined if we could already predict overweight at the age of 5 years by applying the prediction model at the age of 1 year by comparing the $\mathrm{PI}_{\mathrm{m}}$ and the $\mathrm{PI}_{\mathrm{e}}$ values. If a child has a $\mathrm{PI}_{\mathrm{m}}>\mathrm{PI}_{\mathrm{e}}+2 \mathrm{SD}$ value at the age of 1 year, the child is at risk for overweight at the age of 5 years, according to our hypothesis. We calculated the amount of children that exceeded the different SD ranges for the overweight group and compared them to the control group to see if our hypothesis is true. The sensitivity, specificity, likelihoods ratios and the diagnostic odds ratios of our model were calculated ${ }^{11}$. The higher the score for the diagnostic odds ratio, the higher the discriminant power of the model or the test. Thereafter, we compared our prediction model with the 2 currently used methods to estimate (ab)normal growth of children:

a. The often used weight for length growth chart, using a cut-off for overweight of $+2 \mathrm{SD}^{12}$

b. The PI calculation, using a cut-off for overweight of $+2 \mathrm{SD}^{12}$.

We applied the 3 methods at the age of 1 year. Because only weight and length measurements at the age of 1 year were needed for the examination of the growth chart and the calculation of PI at that age, we were able to include more children for method 1 and 2 of our study (118 and 119 resp.).

The mean birth weight, mean weight at the age of 1 year, mean PI at the age of 1 year, mean difference of $\mathrm{PI}_{\mathrm{m}}$ and $\mathrm{PI}_{\mathrm{e}}$ at the age of 1 year, corresponding standard deviations and their significance and 95\% confidence interval were also examined for the overweight and control group by using a two sided t-test, to gain more insight into the composition of the two groups, to compare the groups and to determine if certain parameters are significant predictors for overweight at the age of 5 years.

\section{Results}

Of all the 109 children, who had developed overweight at the age of 5 years, 80 children $(73 \%)$ had a $\mathrm{PI}_{\mathrm{m}}>\mathrm{PI}_{\mathrm{e}}$ at the age of 1 year. 50 of these 80 children $(46 \%$ of 109) had a $\mathrm{PI}_{\mathrm{m}}>\mathrm{PI}_{\mathrm{e}}+2 \mathrm{SD}$ at the age of 1 year. 
29 Children $(27 \%)$ had a $\mathrm{PI}_{\mathrm{m}}<\mathrm{PI}_{\mathrm{e}}$ at the age of 1 year. 9 of these 29 children $(8 \%$ of 109) had a $\mathrm{PI}_{\mathrm{m}}<\mathrm{PI}_{\mathrm{e}}-2 \mathrm{SD}$ at the age of 1 year (Figure 1). A skewed distribution can be seen.

Of all the 111 children, who did not develop overweight at the age of 5 years, 49 children $(44 \%)$ had a $\mathrm{PI}_{\mathrm{m}}>\mathrm{PI}_{\mathrm{e}}$ at the age of 1 year. 18 Of these 49 children $(16 \%$ of 111) had a $\mathrm{PI}_{\mathrm{m}}>\mathrm{PI}_{\mathrm{e}}+2 \mathrm{SD}$ at the age of 1 year.

62 Children (56\%) had a $\mathrm{PI}_{\mathrm{m}}<\mathrm{PI}_{\mathrm{e}}$ at the age of 1 year. 23 of these 62 children $(21 \%$ of 111) had a $\mathrm{PI}_{\mathrm{m}}<\mathrm{PI}_{\mathrm{e}}-2 \mathrm{SD}$ value at the age of 1 year (Figure 1 ).

An equal distribution can be seen in the control group.

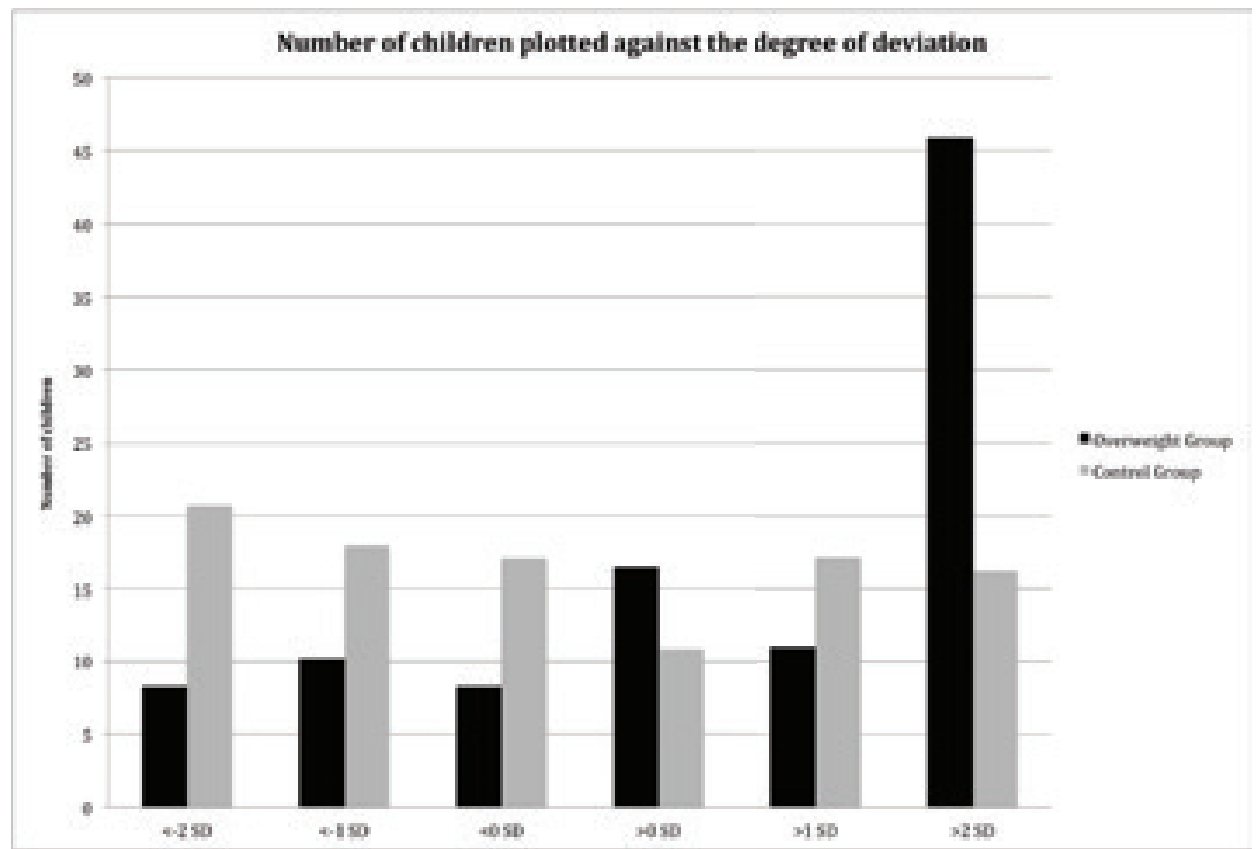

Figure 1: $\quad$ Number of children plotted against the degree of deviation of the SD of the difference of $\mathrm{PI}_{\mathrm{m}}$ and $P \mathrm{I}_{\mathrm{e}}$.

Of these 220 children, $68(31 \%)$ have a $\mathrm{PI}_{\mathrm{m}}>\mathrm{PI}_{\mathrm{e}}+2 \mathrm{SD}$ at the age of 1 year. Apparently, of these 68 children, 50 children (74\%) developed overweight at the age of 5 years. 32 Children have a $\mathrm{PI}_{\mathrm{m}}<\mathrm{PI}_{\mathrm{e}}-2 \mathrm{SD}$ at the age of 1 year. Of these 32 children 9 (28\%) appear to become overweight at the age of 5 years. By analyzing the individual data of this group, most of these children become heavier from the age of 2 years onwards. 23 of these $32(72 \%)$ children appear to have a normal weight at the age of 5-6 years; none of them are underweight at that age. 
To compare our model with other methods (using the weight for length growth chart and calculation of PI) to estimate the growth of children, we calculated the sensitivity and specificity of these methods, all applied at the age of approximately 1 year and using + 2SD as cut-off for overweight, shown in Table 1-3.

The sensitivity of our model is $46 \%$ (50/109). In other words, $46 \%$ of children with a $\mathrm{PI}_{\mathrm{m}}>\mathrm{PI}_{\mathrm{e}}+2 \mathrm{SD}$ at the age of 1 year developed overweight at the age of 5 years. The specificity is $84 \%$ (93/111). In other words $84 \%$ of the children with a $\mathrm{PI}_{\mathrm{m}}<\mathrm{PI}_{\mathrm{e}}$ $+2 \mathrm{SD}$ at the age of 1 year did not develop overweight at the age of 5 years. The likelihood ratio for positive outcomes (sensitivity / 1-specificity) is 2.8 and for negative outcomes (1-sensitivity / specificity) 0.6. The diagnostic odds ratio (true positive * true negative / false positive * false negative) is 4.4 .

The accuracy to predict overweight at the age of 5 years, based on the prediction model applied at the age of 1 year, is 65\% (143/220).

Table 1: Sensitivity (true positive) and specificity (true negative) of the prediction model (applied at 1 year, for prediction of overweight at the age of 5 years).

\begin{tabular}{llll}
\hline & Overweight & Not overweight & TOTAL \\
\hline $\mathrm{PI}_{\mathrm{m}}>\mathrm{PI}_{\mathrm{e}}+2 \mathrm{SD}$ & $50(46 \%)$ & $18(16 \%)$ & 68 \\
& True positive & False positive & \\
$\mathrm{PI}_{\mathrm{m}}<\mathrm{PI}_{\mathrm{e}}+2 \mathrm{SD}$ & $59(54 \%)$ & $93(84 \%)$ & 152 \\
& False negative & True negative & \\
& & & 220 \\
TOTAL & 109 & 111 & \\
\hline
\end{tabular}

Se: 46\%; Sp: 84\%; LR +: 2.88; LR -: 0.64; DOR: 4.4

$\mathrm{PI}_{\mathrm{e}}=$ Expected Ponderal Index, $\mathrm{PI}_{\mathrm{m}}=$ Measured Ponderal Index,

$\mathrm{SD}=$ Standard deviation.

$\mathrm{Se}=$ Sensitivity, $\mathrm{Sp}=$ Specificity, LR $+=$ Positive likelihood ratio, LR $-=$ Negative likelihood ratio, DOR= Diagnostic odds ratio.

The sensitivity of the weight for length growth chart at the age of 1 year and the PI calculation at the age of 1 year is $16 \%$ and $28 \%$ respectively. The specificity values are $95 \%$ and $89 \%$ respectively. Likelihood ratios for positive outcomes are 3.2 respectively 2.5; those for negative outcomes are 0.8 for both models. The diagnostic ratios are 3.6 respectively 3.1 .

The accuracy of the weight for length growth chart at the age of 1 year and PI calculation at the age of 1 year is $56 \%$ and $58 \%$ respectively. 
Table 2: Sensitivity (true positive) and specificity (true negative) of weight for length growth chart (applied at 1 year, for prediction of overweight at the age of 5 years).

\begin{tabular}{llll}
\hline & Overweight & Not overweight & TOTAL \\
\hline Weight for length $>+2$ SD $19(16 \%)$ & $6(5 \%)$ & 25 \\
True positive & False positive & \\
Weight for length $<+2$ SD $99(84 \%)$ & $\begin{array}{l}112(95 \%) \\
\text { True negative }\end{array}$ & 211 \\
& False negative & & \\
TOTAL & 118 & 118 & 236 \\
\hline
\end{tabular}

Se: 16\%; Sp: 95\%; LR+: 3.2; LR-: 0.88; DOR: 3.6

$\mathrm{SD}=$ Standard deviation.

$\mathrm{Se}=$ Sensitivity, $\mathrm{Sp}=$ Specificity, LR $+=$ Positive likelihood ratio, LR $-=$ Negative likelihood ratio, DOR= Diagnostic odds ratio.

Table 3: Sensitivity (true positive) and specificity (true negative) of PI calculation (applied at 1 year, for prediction of overweight at the age of 5 years).

\begin{tabular}{llll}
\hline & Overweight & Not overweight & TOTAL \\
\hline PI $>+2$ SD & $33(28 \%)$ & $13(11 \%)$ & 46 \\
& True positive & False positive & \\
PI <+2SD & $\begin{array}{l}86(72 \%) \\
\text { False negative }\end{array}$ & $\begin{array}{l}106(89 \%) \\
\text { True negative }\end{array}$ & 192 \\
& & 119 & 238 \\
TOTAL & 119 & &
\end{tabular}

Se: 28\%; Sp: 89\%; LR+: 2.55; LR-: 0.81; DOR: 3.1

$\mathrm{PI}=$ Ponderal Index, $\mathrm{SD}=$ Standard deviation.

$\mathrm{Se}=$ Sensitivity, $\mathrm{Sp}=$ Specificity, LR $+=$ Positive likelihood ratio, LR $-=$ Negative likelihood ratio, DOR= Diagnostic odds ratio.

By comparing the two study groups (overweight versus not overweight at the age of 5 years), we also evaluated birth weight and weight, PI and the difference of $\mathrm{PI}_{\mathrm{m}}$ and $\mathrm{PI}_{\mathrm{e}}$ at the age of approximately 1 year. The mean birth weight in the overweight group is 68 grams (gr) higher than in the control group. Also the mean weight at the age of 1 year is 1036.42 gr higher, the PI at the age of 1 year is 0.17 higher and the mean difference of $\mathrm{PI}_{\mathrm{m}}$ and $\mathrm{PI}_{\mathrm{e}}$ at the age of 1 year in the overweight group is 0.16 higher.

By using two sided t-tests, it is possible to calculate the corresponding significances (according to a 95\% confidence interval (CI)). Birth weight is not statistically significant predictor for overweight at the age of 5 years $(p=0.35)$. Nevertheless, weight, $\mathrm{PI}$ and difference of $\mathrm{PI}_{\mathrm{m}}$ and $\mathrm{PI}_{\mathrm{e}}$ at the age of approximately 1 year are highly significant predictors (Table 4). 
Table 4: Mean birth weight, mean weight at the age of 1 year, mean PI at the age of 1 year, mean difference of $\mathrm{PI}_{\mathrm{m}}$ and $\mathrm{PI}_{\mathrm{e}}$ at the age of 1 year, corresponding standard deviations, 95\% confidence interval and significance for the overweight- and control group.

\begin{tabular}{lllll}
\hline & Overweight & Not overweight & CI 95 \% & $\mathrm{p}$ \\
\hline Mean birth weight (gr) & $3441.64 \pm 548.34$ & $3373.63 \pm 532.63$ & $-75.63-211.65$ & 0.35 \\
$\begin{array}{l}\text { Mean weight at the age of 1 } \\
\text { year (gr) }\end{array}$ & $10959.07 \pm 1351.37$ & $9922.65 \pm 1135.33$ & $705-1367.84$ & $<0.0001$ \\
$\begin{array}{l}\text { Mean PI at the age of 1 year } \\
\text { Mean difference, PIm and PIe }\end{array}$ & $2.36 \pm 0.24$ & $2.19 \pm 0.20$ & $0.11-0.23$ & $<0.0001$ \\
\begin{tabular}{l} 
at the age of 1 year \\
\hline
\end{tabular}
\end{tabular}

$\mathrm{PI}=$ Ponderal Index, $\mathrm{PI}_{\mathrm{e}}=$ Expected Ponderal Index, $\mathrm{PI}_{\mathrm{m}}=$ Measured Ponderal Index, $\mathrm{CI}=$ Confidence Interval, $\mathrm{p}=$ Significance, $\mathrm{gr}=$ Grams.

Table 5 shows an example of the course of the PI values of an individual child until the age of 1 year. In Figure 2, the graph of these values is shown. The child has a PI at birth of 2.71. Following the above mentioned formula this child has a $\mathrm{PI}_{e}$ at the age of 1 year of 2.27. Taken the range of 2SD (based on the total population) into account, the $\mathrm{PI}_{\mathrm{e}}$ range of this individual will be 2.12-2.42 (as shown in Figure 2) at the age of 1 year. The child appears to have a $\mathrm{PI}_{\mathrm{m}}$ at 1 year of 2.64 (as shown in Figure 2). According to our prediction model, this child is at risk of becoming overweight.

Table 5: The $\mathrm{PI}_{\mathrm{m}}$ and the $\mathrm{PI}_{\mathrm{e}}$ range (2SD) of an individual child are calculated at different ages until the age of 1 year.

\begin{tabular}{lll}
\hline Age (months) & $\mathrm{PI}_{\mathrm{m}}$ & $\mathrm{PI}_{\mathrm{e}}$ range \\
\hline 0 & 2.71 & $2.71 \pm 0.15$ \\
3 & 2.74 & $2.61 \pm 0.15$ \\
5.3 & 2.7 & $2.52 \pm 0.15$ \\
9 & 2.71 & $2.39 \pm 0.15$ \\
12 & 2.64 & $2.27 \pm 0.15$ \\
\hline
\end{tabular}




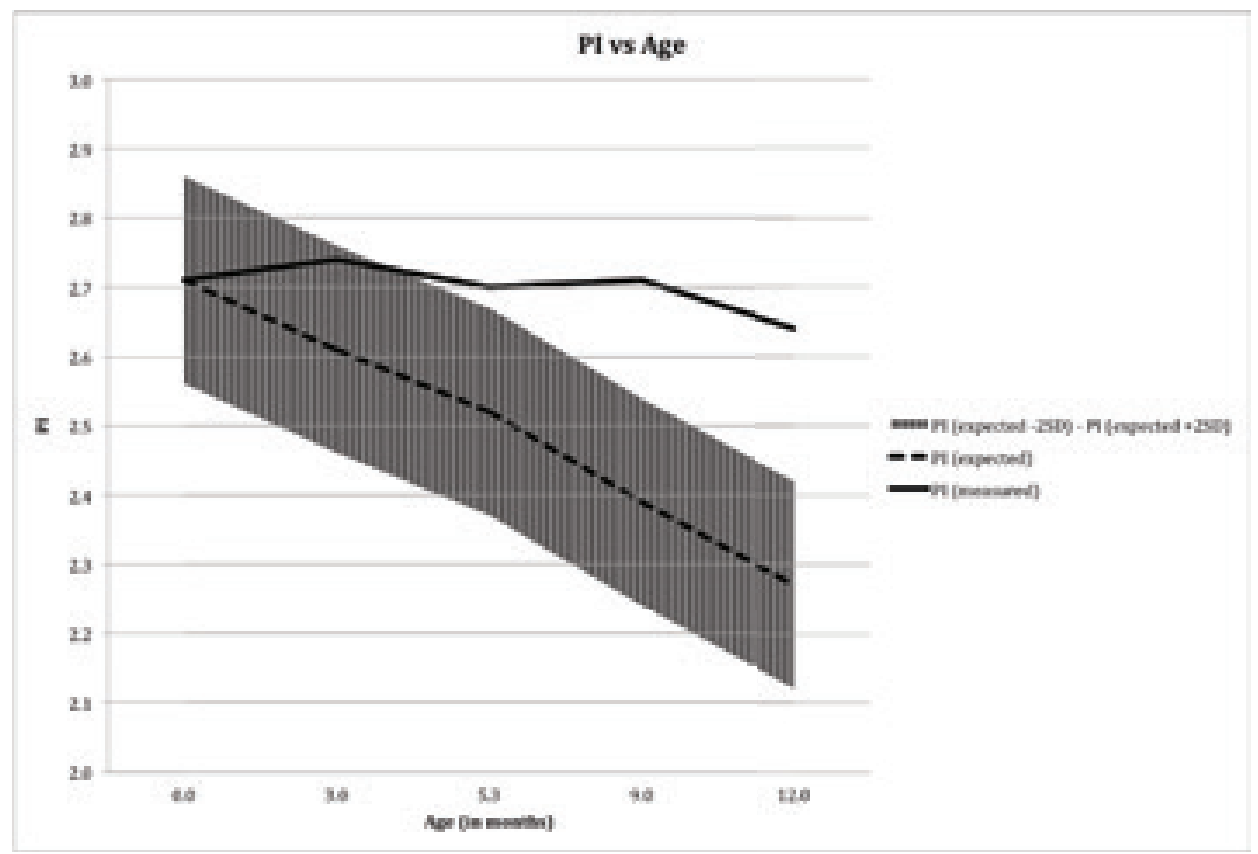

Figure 2: $\mathrm{PI}$ is plotted against age (in months). The $\mathrm{PI}_{\mathrm{m}}$ line, the $\mathrm{PI}_{\mathrm{e}}$ line and the $\mathrm{PI}_{\mathrm{e}}$ range are shown. If a child has a $\mathrm{PI}_{\mathrm{m}}$ value that is above or underneath the area of the $\mathrm{PI}_{\mathrm{e}}$ range, the child is at risk to develop an abnormal growth.

In Table 5 the values of PI expected decrease in time, because of the relative high PI at start. These values show the regression to the mean ${ }^{13}$. This is the phenomenon that growth is changing for most children, dependent on their starting value. In the prediction model the regression to the mean is taken into account.

It has to be mentioned that, if a child has a $\mathrm{PI}_{\mathrm{m}}$ at the age of 1 year that is aberrant of the $\mathrm{PI}_{\mathrm{e}}$ at that age, it does not mean that the child is actually over- or underweight or that their actual weight is abnormal. This value only shows that the child tends to have an abnormal growth, according to the individual growth pattern of the child. In other words: These children deviate in positive or negative sense from their expected growth pattern (as shown in Figure 2). 


\section{Discussion}

The prediction model we describe assumes that the expected growth pattern of an individual child can already be used in the first year of life as an indication for future trend in growth. In this early period, mainly genetic, nutritional and some behavioral factors (like crawling and walking) will determine the development of overweight. This study shows that the calculation of PI appears to be a better tool to detect and diagnose overweight than using the weight for length growth charts.

To predict overweight at the age of 5 years, the best method appears to be the prediction model, followed by the calculation of PI. Using the weight for length growth chart appears to be the poorest predictor for overweight by comparing these 3 methods. The sensitivity, specificity and the diagnostic odds ratios of these 3 methods (Tables 1-3) confirm this statement. The specificity of our prediction model is lower than the other methods, but the sensitivity is much higher. By using the prediction model, in $16 \%$ of all cases a child may be wrongly appointed to become overweight and parents may receive redundant advices to prevent overweight. In $54 \%$ of all cases a child with an overweight risk will be missed. Compared to the weight for length growth chart and PI calculation ( $84 \%$ and $72 \%$ resp.), this is a much lower percentage. To avoid methodological complications, we calculated the diagnostic odds ratio, besides the sensitivity and specificity. The diagnostic odds ratio has the advantage to be less sensitive for changes in composition of the study population. It summarizes the diagnostic test performance. The diagnostic odds ratio is higher in our prediction model than in the other 2 methods. The higher the diagnostic odds ratio, the higher the discriminant power of the model. By applying the prediction model, more parents of children with an overweight risk will be warned.

Several studies tried to find parameters to predict overweight in childhood. Steur et al found that there are several characteristics that are available at birth, which are predictors of overweight. These characteristics are: Paternal and maternal BMI, female gender, smoking in the parental house, birth weight and hospital delivery ${ }^{14}$. Reilly et al identified 8 risk factors in early life (up to 3 years of age) for obesity: Paternal obesity, very early (43 months) BMI or adiposity rebound, more than 8 hours watching television per week at the age of 3 years, catch-up growth, standard deviation scores (highest quarter) at 8 and 18 months, weight gain in the first year, birth weight and short ( $<10.5$ hours) sleep duration at the age of 3 years $^{15}$. Also promoting breastfeeding is important in the prevention of overweight, as Armstrong found that breastfeeding is associated with a reduction in childhood obesity risk $^{16}$. Tamayo stated that a low childhood socioeconomic status (SES) is a risk factor for overweight and obesity later in life ${ }^{17}$. All these predictors can be useful in the prevention of overweight by health care physicians. If these risk factors are taken into account at an early age and discussed with parents, it is possible to con- 
tribute to the prevention of overweight at an early age. However, most of these risk factors are mainly subjective and difficult to change. Therefore, a more objective parameter like the PI in our prediction model can be very helpful in preventive strategies. If the meaning of the PI value is carefully explained to the parents, this might contribute to a greater awareness and risk perception of overweight. The prediction model, as described in this manuscript, can simply be used in practice and added to the resources that health care practitioners use in preventing overweight in childhood, at the moment.

Most interventions, targeted at the prevention and reduction of overweight, are applied from the age of 2 years. Mainly, they are focused on environmental and behavioral factors, like promoting healthy food and drinks, creating sport facilities and safe zones for cycling to school, restrictions on the advertising of soft drinks and energy dense food and demotivating sedentary recreation, like watching TV or playing computer games ${ }^{18}$. In this manuscript we focused on the prediction of overweight by using the PI in early childhood (0-1 year). By using our model, prediction and thereby prevention of overweight can already initiated at a very early age, even before it can be diagnosed.

In the Netherlands the Youth Health Care is concerned with the healthy physical and psychosocial development of children, between 0 and 19 years of age. With respect to the growth of children in their early years, the Youth Health Care examines children regularly during their visits to the Youth Health Care centers with their parents. During the first year of life, there are approximately 10 measurements of the child by the youth health care, thereafter approximately 5 measurements until the age of 5 years. By means of these frequent examinations, it is possible to monitor the growth of a child and to intervene at the moment that a child tends to become overweight. Our prediction model can be a useful additional instrument in the prevention of overweight.

If this prediction model could be implemented in the electronic child record, the Youth Health Care physician, pediatrician or nurse can show parents the risk of their child of becoming overweight, taken a cut-off point of $\mathrm{PI}_{m}>\mathrm{PI}_{e}+2 \mathrm{SD}$ at the age of 1 year. Only the data of PI at birth, based on birth weight and birth length and the actual age of the child are needed in the risk calculation. By digital registration, it is possible to immediately show the risk of becoming overweight on their computer screen. For example, if the child is not at risk, the screen will show a green color; if the child is at risk, the screen will show a red color.

To countervail the risk that the parents do not accept the advice of the health care practitioner, because the risk is a calculated risk which does not exist yet, it is of great importance to train the health care practitioners in motivational interviewing. Motivational interviewing assumes that behavior change is affected more by moti- 
vation than by information ${ }^{19}$. Parents have to be clearly explained how the growth of their child is evolving. Motivational interviewing by pediatricians and dietitians seems a promising office-based strategy to motivate parents to cooperate in the prevention of childhood overweight and obesity ${ }^{20}$.

Also the development of underweight must not be neglected. Underweight is an underappreciated problem, because the main focus is on overweight and obesity, nowadays. However, a trend in underweight could be detected by comparing nationwide Dutch growth studies from 1964-1966 and 1996-1997²1.

In our study all the children in the control group, who were at risk to develop underweight $\left(\mathrm{PI}_{\mathrm{m}}<\mathrm{PI}_{\mathrm{e}}-2 \mathrm{SD}\right.$ at the age of 1 year), had a normal weight at the age of 5 years. Though, it is important to monitor not only those children at risk of becoming overweight, but also children at risk of becoming underweight: The health care physician must be aware of a possible development of certain co morbidities, like celiac disease. Unfortunately, we cannot prove that the prediction model can be used to predict the risk of becoming underweight

\section{Conclusion}

By means of this prediction model, it is possible to predict the expected value of the PI at the age of 1 year by known PI at birth. If the measured value of PI at the age of 1 year exceeds the expected value, the child may be at risk to develop obesity at the age of 5 years. By using this prediction model, we are able to estimate the growth pattern of an infant. Our model seems better to predict overweight than the currently used methods using growth charts and PI formula only. If the actual growth pattern of the infant does not fit into the expected growth, intervention may be needed to prevent abnormal growth. Health care practitioners, who are trained in motivational interviewing techniques, can use this prediction model in preventing overweight in children. 


\section{References}

1. Onis M, Blossner M, et al. Am J Clin Nutrition 2010; 92:1257-1264.

2. Reilly JJ, Kelly J. Long term impact of overweight and obesity in childhood and adolescence on morbidity and premature mortality in adulthood: Systematic review. Int J Ob 2011; 35:891-898.

3. Lee YS. Consequences of childhood obesity. Annals academy of Medicine Singapore 2009; 38:75-81.

4. Griffiths LJ, Wolke D, et al. Obesity and bullying: Different effects on boys and girls. Arch Dis Child 2006; 91:121.

5. Viner RM, Cole TJ. Adult socioeconomic, educational, social and psychological outcomes of childhood obesity: a national birth cohort study. BMJ 2005; doi:10.1136/bmj.38453.422049.EO.

6. Hirasing RA, Fredriks AM, et al. Toegenomen prevalentie van overgewicht en obesitas bij Nederlandse kinderen en signalering daarvan aan de hand van internationale normen en nieuwe referentie diagrammen [Increased prevalence of overweight and obesity in Dutch children and detection according to international norms and new reference diagrams]. Ned Tijdschr Geneesk 2001; 145:1303-1308.

7. Ernst MAB, Gerver WJM, et al. A prediction model to prevent abnormal weight in childhood.

8. Rohrer F. Der Index der Korperfulle als Mass des Ernahrungszustandes [The index of body composition as a measure of nutrition status]. Muncher Med Wrsch 1921; 68:580-582.

9. Ditmier LF. New developments in obesity research. Nova Science Publishers, Hauppage, New York, 2006, ISBN 1-60021-296-4.

10. Davies DP. Size at birth and growth in the first year of life of babies who are overweight and underweight at birth. Proc Nutr Soc 1980 (39):25-33.

11. Bouter LM, Van Dongen MCIM. Epidemiologisch onderzoek; opzet en interpretatie [Epidemiology: methodology and interpretation]. Bohn Stafleu Van Loghum 2000, ISBN 9031330981.

12. Gerver WJM, De Bruin R. Paediatric Morphometrics, A reference manual. (second extended edition). University Press Maastricht, The Netherlands, ISBN 905278307 1; 2001.

13. Barnett AG, van der Pols JC, Dobson AJ. Regression to the mean: What it is and how to deal with it. Int J Epidemiol 2005; 34:215-220.

14 Steur M, Smit, H, et al. Predicting the risk of newborn children to become overweight later in childhood: The PIAMA birth cohort study. Int J Paed Obesity 2011; 6:170-178.

15. Reilly JJ, Armstrong J, et al. Early life risk factors for obesity in childhood: Cohort study. BMJ 2005; doi:10.1136/bmj.38470.670903.EO.

16. Armstrong J, Reilly JJ. Breastfeeding and lowering the risk of childhood obesity. Lancet 2002; vol. 359,8:2003-2004.

17. Tamayo T, Christian H, et al. Impact of early psychosocial factors (childhood socioeconomic fators and adversities) on future risk of type 2 diabetes, metabolic disturbances and obesity: A systematic review. BMC Public Health 2010, 10:525.

18. Lobstein T, Baur L, et al. Obesity in children and young people: A crisis in public health. Ob Rev 2004; 5 (Suppl. 1):4-85.

19. Reniscow K, Davis R, et al. Motivational interviewing for pediatric obesity: Conceptual issues and evidence review. J Am Diet Assoc 2006; 106(12):2024-33.

20. Schwartz RP, Hamre R, et al. Office based motivational interviewing to prevent childhood obesity: A feasibility study. Arch Pediatr Adolesc Med 2007; 161(5):495-501.

21. Ernst MAB, Gerver WJM, et al. Obesity in childhood: A secular trend or an epidemic disease? J Child Health Care 2012; 17(1):30-40. 
THE USE OF A PREDICTION MODEL TO PREVENT ABNORMAL WEIGHT IN CHILDHOOD IN THE YOUTH HEALTH CARE PRACTICE 



\section{CHAPTER 7}

\section{DISCUSSION AND}

VALORIZATION ADDENDUM

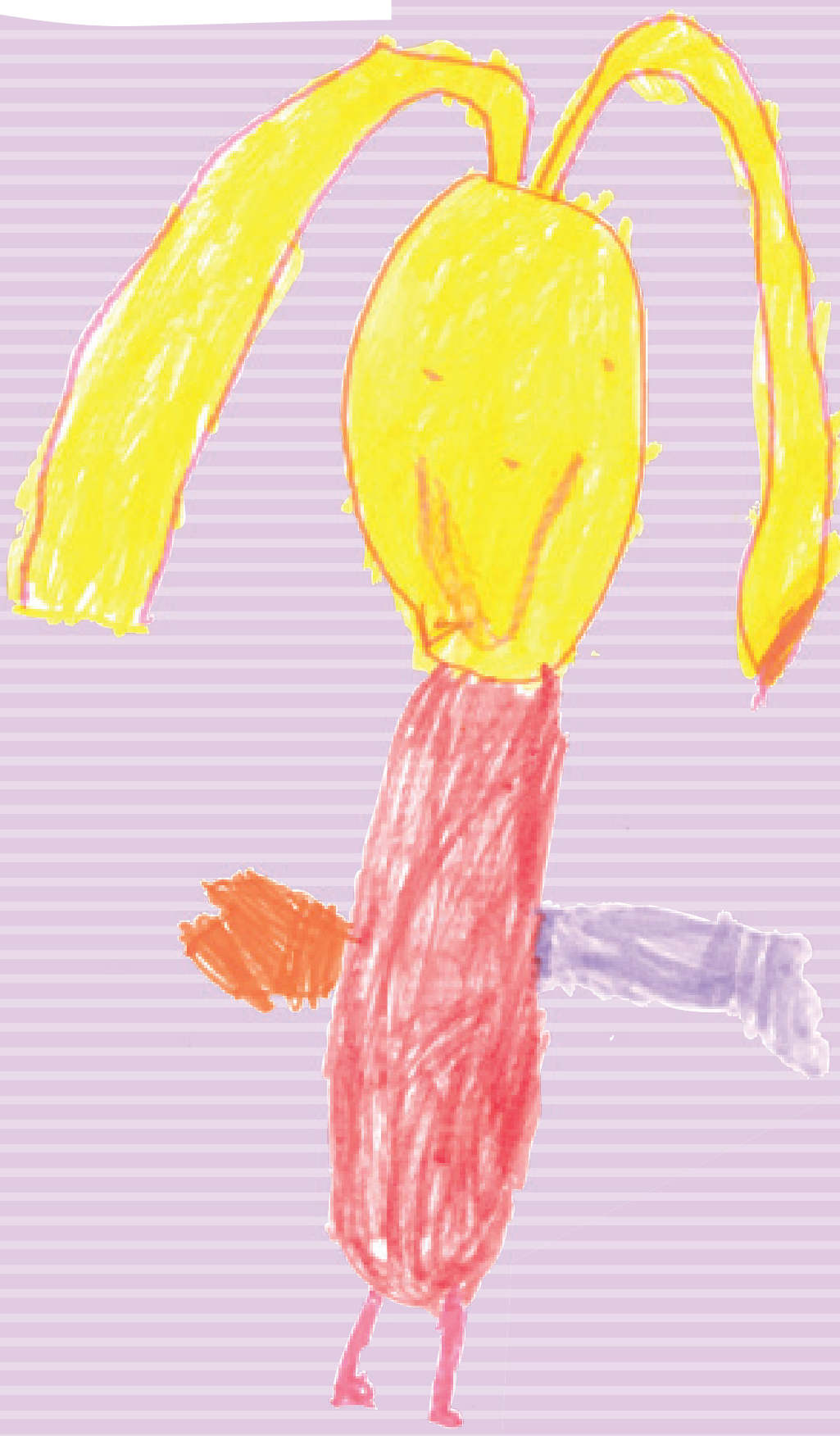


CHAPTER 7 
Already for many years we have been confronted with a worldwide increasing tendency of children who become obese. At the same time, there is also evidence that obesity in childhood is on the basis of the metabolic syndrome in adulthood with the well-known pathology of hypertension, cardiovascular disease, diabetes mellitus and stroke. In this study we tried to gain better insight in the development of obesity, the possibilities of prevention and what obesity means in terms of body composition.

The first question to study concerned the epidemiology of obesity. Although it is well-known that the origin of obesity in adulthood often has to be found in childhood, we did not find any increase in weight of the neonate born during the last decades. In other words, there is no increase in prenatal growth despite a mean increase in weight and length of the mothers known as the secular trend. In explanation may it be stated that it is assumed that the intrauterine environment and the placental nutrition supply prevent the fetus from becoming overgrown to protect the mother herself. The placenta is not simply a passive conduit for nutrients but also responds to both maternal and fetal signals, altering placental transport and metabolic function ${ }^{1,2}$. On the other hand, it is described that maternal weight gain in early pregnancy has an influence on fetal weight probably mediated through raised placental mass ${ }^{3,4}$. Nevertheless, the general idea is that if a child has the tendency to achieve a weight and height outside the physiological borders, there might be a mechanism to restrict the further intrauterine growth as is shown in our data of birth weight and length gathered during the last years.

The main concerns of obesity are the comorbidities like the metabolic syndrome and numerous psychosocial problems, which transfer obesity into a serious disease. Because the roots of obesity can often be found in childhood, it is significant to discern those children who are becoming obese just based on abnormal food intake often combined with a less degree of physical exertion and those who suffer from insulin resistance from birth onwards. The last group is especially recognized in the infants born after intra uterine growth retardation, the small for gestational age (SGA) children. Thanks to the longitudinal growth study during the first four years of age of a healthy Dutch population ${ }^{5}$, we were able to analyze the postnatal growth of individual children during this period.

We realize that the reference population was taken ten years ago but at the same time these reference data compared to the last Dutch nationwide growth study show that the so-called secular trend has come to a stop for height. However, it did not come to a stop for weight. This tendency of becoming taller and heavier was originally an important indication of a population whose health gained thanks to better feeding and less disease. While the mean increase in height stopped already since more than ten years, weight gain is still going on for the population as a whole. For that reason a comparison with an older reference population it is signifi- 
cant to be informed about the start of the discrepancy between height and weight of the Dutch population. Taking into account the information that height does not increase anymore, the increase in Body Mass Index (BMI), which was seen in the postnatal data, means a higher increase in weight.

\section{Methods of analyzing growth of children}

There are several methods to analyze the growth of a child and to determine overweight or obesity. One can compare particular children of the same age, gender and population to judge if its weight and height are within the normal range for the population. Usually weight and height are expressed as a function of age. Weight can also be expressed in relation to height as the BMI defined as weight (kg) divided by squared height $\left(\mathrm{m}^{2}\right)$. However, the above-mentioned tendency of the population to become heavier with steady size led to an increase in the BMI as followed from the formula. In case of an equal weight to height ratio a child (below the age of 10 years) with a taller height has a higher BMI in contrast to a child (below the age of 10 years) with a smaller height, taking the P3, P50 and P97 values into account. Therefore the expression of weight versus height is more reliable in children. $\mathrm{A}$ limitation of the anthropometric approach of weight is that the BMI as well as weight for height does not distinct between fat mass (FM) and fat-free mass (FFM) ${ }^{6}$. In adipose children it is reasonable to ascribe the weight gain to an increase in FM. At the same time in relatively lean children a lower weight is largely due to a shift from FM to FFM. Because a large part of the FM is situated in the abdominal region, Fredriks stated that waist circumference can be used as a better tool to screen for increased abdominal fat in children ${ }^{7}$.

To measure total body fat one needs the use of other methods. A rather complex method is the underwater weighing. The difference of weight in the open air and under water gives a good indication of the FM. An easy and reliable method is the measurement of the FFM by means of Deuterium. Deuterium is a stable isotope of hydrogen of which the natural presence in the body fluids is knowable by measuring Deuterium in the urine. After a known gift of Deuterium the new concentration in the urine after equilibration of the Deuterium in all body segments, is equivalent with the total body FFM. Distracting the result from total body weight delivers a good estimate of total body fat. Minimal changes in body composition can be found by using the Deuterium method. 


\section{Small for gestational age children}

Besides the evidence of the origin of the metabolic syndrome in SGA children, it is also remarkable that their growth in length and height often stay behind the norm. One of the factors mentioned with respect to the stunted growth SGA children is reduced sensitivity for the insulin-like growth factor 1 (IGF-1) ${ }^{8}$. IGF-1 is mainly secreted by the liver as a result of stimulation by growth hormone. IGF-1 expression is required for achieving maximal growth. Short SGA children show plasma IGF-1 levels that are in the lower normal range 9 . For that reason these children are treated with recombinant human growth hormone (rhGH) nowadays. In general they respond very good on this treatment and correct their height towards their genetically defined percentile. At the same time it is known from that treatment of growth hormone deficient (GHD) children with rhGH results in a change of the metabolism ${ }^{10}$. This change is assumed to be an effect of IGF-I what is a primary regulator of systemic anabolism and muscle growth ${ }^{11}$. Growth hormone deficiency is associated with increased body fat and a lower lean body mass. These changes in body composition are associated with metabolic derangements including insulin resistance. They normalize with growth hormone replacement therapy ${ }^{12}$.

In this thesis we showed that treatment with rhGH has also a positive metabolic effect on body composition of SGA children. The treatment with rhGH causes a shift in body composition of FM towards FFM. After treatment with rhGH, SGA children show an increase in height but also in weight. The detected increase in weight is based on an increase in FFM and not in FM. This means, as mentioned before, that the body composition in SGA children improves after receiving rhGH treatment. In SGA children rhGH treatment prevents overweight and thereby the metabolic syndrome.

To evaluate adequate and inadequate responders to rhGH therapy, with respect to height, changes in body composition can be measured. The change in body composition is an actual tool in predicting the individual response on rhGH treatment. By using this method rhGH therapy can be given only to adequate responders and it is possible to prevent aimless administration.

In obese children there exists a decrease in growth hormone (GH) secretion what is fully reversible when body weight is normalized ${ }^{13}$. A decrease in spontaneous $\mathrm{GH}$ release in obesity has been confirmed in several comparative studies on the 24hour secretion of $\mathrm{GH}$ in normal weight ${ }^{14}$ and obese children ${ }^{13}$, 15 . In obese children, GH secretion may be as low as in poorly growing children with classical GHD ${ }^{16}$. Investigation of the pattern of factors potentially influencing $\mathrm{GH}$ secretion confirmed a significant and independent impact of fat mass. Relative adiposity acts as a negative determinant of the frequency and amplitude of GH secretory bursts. They are associated with an increased GH clearance leading to a lower GH half-life time, 
suggesting a defect both in secretion and clearance ${ }^{15,17}$. Alterations in GH receptors and circulating GH-binding proteins support these changes ${ }^{18,19}$.

Bocca et al showed that insulin resistance and cardiovascular risk factors are already evident in overweight and obese children with a mean age of 4.7 years. An association exists between insulin resistance and BMI, waist circumference and percentage body fat ${ }^{20}$. The question arises if obesity will improve by rhGH treatment. It is dubious to give rhGH treatment to obese children. However, if a child suffers from obesity due to an insulin resistance, rhGH therapy is theoretically indicated but, as in all cases of insulin resistance known as diabetic type II, the first step is lowering weight by means of dietary measures.

One can discuss if rhGH treatment is indicated in very obese children. Like bariatric surgery, these treatment options are controversial in pediatric patients. Bariatric surgery in children results in clinically significant weight loss, but also has the potential for serious complications ${ }^{21}$. Therefore, this is not a usual treatment option. But in the case of severe obesity, where other treatment options failed, it is questionable if more risky therapies, under strict monitoring, are indicated if we take the severe comorbidities of obesity into account.

\section{Costs}

Not only the health consequences of overweight in childhood are a serious problem, but also the financial aspect. Consequences and comorbidities of obesity like cardiovascular diseases, DM type II, orthopedic problems, skin abnormalities and psychosocial problems such as underachievement in school and lower self-esteem, will lead to rising health care costs if the incidence of obesity is increasing in the future. Treating obesity and obesity-related conditions costs billions of dollars a year. By one estimate, the United States spent $\$ 190$ billion on obesity-related health care expenses in 2005, double previous estimates ${ }^{22}$. The medical costs of obesity-related illnesses in the United States have been estimated at $\$ 209.7$ billion annually (in $2008)^{23}$.

Not only these direct costs have to be taken into consideration, but also indirect costs like absence from work due to ilness. Obese employees miss more days from work due to short-term absences, long-term disability, and premature death than non-obese employees ${ }^{24}$. Some studies show that obese employees have also lower wages $^{25}$. One can imagine that obese persons with possible psychosocial problems and lower self-esteem due to their weight are less likely to ask for increment in salary or improvement of career options. One can imagine that these problems also apply for children at school. Obese children suffer from bullying, are less selfassured and therefore probably less motivated to go to school. 
Evidently, we can speak of a negative spiral or vicious circle especially of people with a low social economic situation who are obese and stay in this low social economic situation. There is a lot of advertising to buy fast food. Fast food is much cheaper than healthy food and there is an abundance of fast food in supermarket shelves. Due to this overwhelming exposure of cheap, tasty, unhealthy food, it is difficult for lots of people to choose for the more expensive healthy food.

Hollingworth et al performed an economic analysis of interventions to treat childhood obesity. This study showed that interventions are potentially cost effective although cost savings and health benefits may not appear until the sixth or seventh decade of life ${ }^{26}$. From that age on most physical disabilities and health care costs exists. All data show that it is of great importance to prevent people from becoming obese because not only the medical and psychosocial, but also the economic consequences, are alarming.

In The Netherlands an estimated 505.4 million euros is spent on direct consequences of obesity, this is approximately $1.6 \%$ of the total healthcare costs of adults above the age of $20^{27}$.

\section{Prevention programs}

Prevention at an early age is necessary in reducing the problem of obesity or malnutrition and its co-morbidities, which will be a threat for the population in the future. Health professionals, who provide primary care for children, are in the center of the pediatric obesity epidemic and can play a pivotal role in early detection of obesity. Obesity in childhood is one of the most challenging diseases to tackle these days. Once overweight or obesity is manifested, it is very difficult to reduce weight. Also for the Netherlands this tendency prevails and many local, as well as national health programs are focused on reducing the incidence of obesity. Nowadays, lots of preventing programs for overweight have been developed. Most of these programs are focused on healthy food and drinks, stimulating exercise / physical activity and demoralize inactive living. Apparently these programs are not effective enough. Thereby, most programs are aimed at school-aged children and adolescents. Fewer programs have younger children as target group. Because school aged children often suffer already from obesity, prevention at a very early age is of great importance to prevent overweight and obesity instead of treatment.

Multiple studies have investigated the effectiveness and functionality of prevention programs for overweight and obesity in childhood. Cauwenberghe et al found strong evidence of effect for multicomponent interventions on fruit and vegetable intake in children. His finding was based on self-reported dietary behavior. Howev- 
er, interventions that specifically targeted children from lower socio-economic status groups showed limited evidence of effect on behavior while in adolescents just moderate effect was found for educational interventions and multicomponent programs on behavior ${ }^{28}$. Appearance and awareness of its consequences are more prominent present in adolescence than in childhood.

These days in several countries a program is applied called the Triple P Positive Parenting Program. This program has been focusing on the support of parents. It is a multi-level parenting and family support strategy developed by the University of Queensland in Brisbane ${ }^{29}$. The Triple P program has been based on social learning principles and adopts a system-contextual or ecological perspective in supporting parents. The efficacy of Lifestyle Triple $\mathrm{P}$ has been tested in a randomized controlled trial (RCT) in Australia ${ }^{30}$. West et al. showed that their intervention significantly decreased children's body size and body fat, decreased their weight-related problem behavior, increased parental confidence in managing weight-related problem behavior, and decreased ineffective parenting ${ }^{31}$. Moreover, Triple P Positive Parenting Program is applied successfully in the South of The Netherlands.

The Centre for Overweight Adolescent and Children's Healthcare (COACH) from the Maastricht University Medical Centre (MUMC) helps children and adolescents with obesity. By COACH children, adolescents and their parents are accompanied by a multidisciplinary team to treat obesity with dietary-, sport- and psychological advices. Children are coached until they reach the age of 35 years. During this program also scientists will be closely involved. The most important aim is to change life style. After all, prevention of excessive weight gain in children is based on a different mechanism than prevention of weight gain in adults: children can reduce their BMI while growing without losing weight, whereas adults have to lose weight in order to reduce their $\mathrm{BMI}^{32}$.

Parents are the primary caregivers, who are largely responsible for their children's nutrition and physical activity patterns, particularly in the early years of life ${ }^{33}$. Motivational interviewing is a method that can be used to approach parents of children with obesity. Motivational interviewing is a way of approaching people to help them recognizing their problem and to stimulate them to solve this problem. In case of parents with an obese child, this approach is very important. Most parents do not want to admit that their child is too heavy. They are often not aware of the problem and think that their obese child only suffers from a little bit baby fat. They feel attacked and guilty, because they think their education and upbringing is not correct. They will often seek for external factors as cause for the obesity problem of their child. If parents are willing to change their own behavior and thereby improving the health of their children, this is an important step in the prevention of obesity development. 
In a recent American study where trends of obesity in childhood are analyzed, a positive trend was seen: There was a significant decrease in obesity from $14 \%$ in 2003-2004 to 8\% in 2011-2012 in children aged 2 to 5 years old. Also in Germany, a study of children aged 4 to 16 years showed a decline in obesity between 2004 and 2008 among the 4 to 7 years old ${ }^{34}$. At the other ages, a stabilization was seen.

In the Netherlands, the prevalence of obesity in children in the major cities (where many prevention programs have been implemented) has stabilized ${ }^{35}$. Probably prevention programs are working 36 !

\section{Prediction model to detect obesity at an early age}

The prediction model described in this thesis makes it possible to predict if a child in the first year of life runs the risk to develop obesity at the age of five years. The prediction model can also detect the risk to develop obesity in children who still have a weight within the normal range, at the moment of investigation. The prediction model described in this thesis is based on growth data of 387 children and tested in 120 overweight children and 120 control children. After application it appeared that the prediction model was able to predict the risk of becoming overweight in a more reliable way than other often used methods, like weight for length growth chart or the PI calculation.

The prediction model can easily be used in the Youth Health Care practice, but also by general practitioners or pediatricians. The calculation formula on which the model is based can be implemented digitally. Then, it is possible, simply by adding the growth data of a child into the formula, to determine the risk of developing obesity. If the prediction model will be implemented digitally or by an app, the risk to develop obesity can be easily discovered by just pushing a button. Not only health care practitioners can use the digital prediction model, also children and parents can use it. The advantage is that monitoring of the risk of developing obesity is much easier, a possible disadvantage of the use at home is that regular monitoring appointment by youth health care practitioners are skipped. But after all, a more specific and accurate prediction of the risk of developing obesity is a great step forward to prevent obesity and its severe medical, psychosocial and economic consequences. 


\section{References}

1. Roos S, Lagerlöf 0 , et al. Regulation of amino acid transporters by glucose and growth factors in cultured primary human trophoblast cells is mediated by mTOR signaling. Am J Physiol Cell Physiol 2009; 297:C723-C731.

2. Constancia M, Hemberger M, et al. Placental-specific IGF-II is a major modulator of placental and fetal growth. Nature 2002; 417:945-948.

3. Diouf I, Botton J, et al. The EDEN Study Group: Specific role of maternal weight change in the first trimester of pregnancy on birth size. Matern Child Nutr 2012.

4. Swanson LD, Bewtra C: Increase in normal placental weights related to increase in maternal body mass index. J Matern Fetal Neonatal Med 2008; 21:111-113.

5. Gerver WJM, De Bruin R. Paediatric Morphometrics, A reference manual. (second extended edition). University Press Maastricht, The Netherlands, ISBN 905278307 1; 2001.

6. Freedman DS, Sherry D. The validity of BMI as an indicator of body fatness and risk among children. Pediatrics 2009; 124 Suppl 1:S23-34. doi: 10.1542/peds.2008-3586E.

7. Fredriks AM, van Buuren S, et al. Are age references for waist circumference, hip circumference and waist-hip ratio in Dutch children useful in clinical practice? Eur J Pediatr. 2005 Apr;164(4):216-22.

8. de Zegher F, Francois L, et al. Growth hormone treatment of short children born small for gestational age. Trends Endocrin Metab 1998; 9(6):233-237.

9. Volkl Tm, Schwobel K, et al. Spontaneous growth hormone secretion and IGF1:IGFBP3 molar rations in children born small for gestational age (SGA). Growth Horm IGF Res 2004; 14(6):455-461.

10. Hoos MB, Westerterp KR, et al. Short-term effects of growth hormone on body composition as a predictor for growth. J Clin Endocrinol Metab 2003; 88(6):2569-72.

11. Butler AA, Roith DL. Control of growth by the somatropic axis: growth hormone and the insulin-like growth factors have related and independent roles. Annu Rev Physiol 2001; 63: 141-164.

12. Kreitschmann-Andermahr I, Suarez P, et al. GH/IGF-I regulation in obesity-mechanisms and practical consequences in children and adults, Hormone Research Pediatrics 2010; 73(3):153-60.

13. Rasmussen $\mathrm{MH}$, Hvidberg A, et al. Massive weight loss restores 24-hour growth hormone release profiles and serum insulin-like growth factor 1 levels in obese subjects. J Clin Endocrinol Metab 1995; 80:1407-1415.

14. Heptulla R, Smitten A, et al. Temporal patterns of circulating leptin levels in lean and obese adolescents: relationships to insulin, growth hormone, and free fatty acids rhythmicity. J Clin Endocrinol Metab 2001; 86:90-96.

15. Veldhuis JD, Iranmanesh A, et al. Dual defects in pulsatile growth hormone secretion and clearance subserve the hyposomatotropism of obesity in man. J Clin Endocrinol Metab 1991; 72:51-59.

16. Vanderschueren-Lodeweyckx M. The effect of simple obesity on growth and growth hormone. Horm Res 1993; 40:23-30.

I7. Ranmanesh A, Lizarralde G, et al. Age and relative adiposity are specific negative determinants of the frequency and amplitude of growth hormone (GH) secretory bursts and the half-life of endogenous GH in healthy men. J Clin Endocrinol Metab 1991; 73:1081-1088.

18. Lichanska AM, Waters MJ. New insights into growth hormone receptor function and clinical implications. Horm Res 2008; 69:138-145.

19. Lee HC, Huh KB. GH-binding protein in obese men with varying glucose tolerance: relationship to body fat distribution, insulin secretion and the GH-IGF-I axis. Eur J Endocrinol 1999; 140:159-163.

20. Bocca G, Ongering EC, et al. Insulin resistance and cardiovasular risk factors in 3- to 5-year old overweight or obese children. Hormone Research in Paediatrics 2013; 80:201-206.

21. Treadwell JR, Sun F, et al. Systematic review and meta analysis of bariatric surgery for pediatric obesity. Ann Surg 2008; 248(5):763-76.

22. Cawley J, Meyerhoefer C. The medical care costs of obesity: an instrumental variables approach. J Health Econ 2012; 31:219-30.

23. Apovian CM, The clinical and economic consequences of obesity. Am J Manag Care 2013; $19(10$ Suppl):219-28.

24. Colditz GA. Economic costs of obesity. Am J Clin Nutr 1992; 55:503-507. 
25. Colditz GW, Wang, YC. Economic costs of obesity. In: Hu F, Obesity Epidemiology 2008; New York: Oxford University Press.

26. Hollingworth $\mathrm{W}$, Hawkins J. Economic evaluation of life style interventions to treat overweight or obesity in children. Int J Obes 2012; 36(4):559-66.

27. www.rvz.net

28. Cauwenberghe E, Maes L et al. Effectiveness of school-based interventions in Europe to promote healthy nutrition in children and adolescents: systematic review of published and "grey" literature. Br J Nutr 2010; 103(6):781-97.

29. Sanders MR, Markie-Dadds C, et al. Theoretical, scientific and clinical foundations of the Triple PPositive Parenting Program: a population approach to the promotion of parenting competence. Parent Res Pract Monogr. 2003; 1:1-24.

30. West F, Sanders MR, et al. Randomised clinical trial of a family-based lifestyle intervention for childhood obesity involving parents as the exclusive agents of change. Behav Res Ther 2010; 48:11701179.

31. West F. The Lifestyle Triple P Project. Exploring the link between parenting and childhood obesity. University of Queensland, School of Psychology; 2007.

32. Kremers S, Martens M, et al. Programmeringstudie overgewicht, ZonMW ed. Universiteit Maastricht, Rescon; 2008.

33. Gerards S, dagnelie P, et al. Lifestyle Triple P: A parenting intervention for childhood obesity, BMC Public Health 2012; 12:267.

34. Ogden CL, Carroll MD, et al. Prevalence of childhood and adult obesity in the United states, 20112012. JAMA 2014; 311(8):806-814.

35. Schonbeck $\mathrm{Y}$, Talma $\mathrm{H}$, et al. Increase in prevelance of overweight in Dutch children and adolescents: A comparison of nationwide growth studies in 1980, 1997 and 2009. Plos One. 2011, vol. 6, issue 11, e27608.

36. Bluher S, Meigen C, et al. Age-specific stabilization in obesity prevalence in German children: a cross sectional study from 1999 to 2008. Int J Pediatr Obes. 2011; 6(2-2):e199-e206. 



\section{SUMMARY/ \\ SAMENVATTING}

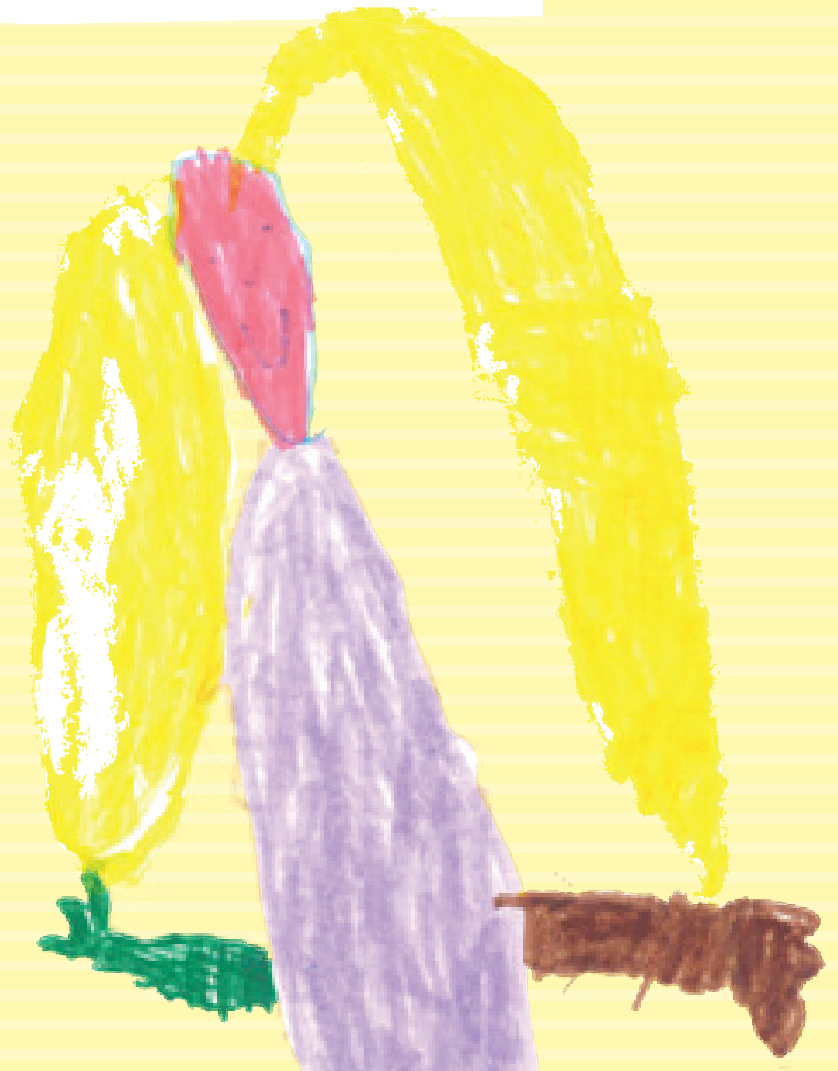




\section{Summary}

Obesity in childhood is nowadays and will be in future one of the greatest health care problems. The metabolic syndrome, characterized by abdominal (central) obesity, elevated blood pressure, elevated fasting plasma glucose, high serum triglycerides and low high-density cholesterol (HDL) levels is one of the dangerous health consequences of obesity. Also joint problems and psychosocial problems can occur. The idea that the origin of the metabolic syndrome has to be found in early life is based on Barker's hypothesis, who stated that malnutrition in utero permanently changes the metabolism.

During the last decades the prevalence of obesity increases in children and thereby the risk of an increasing prevalence in adulthood. It is therefore important to prevent obesity at a young age in childhood, preferably before a child has become obese. A lot of prevention programs for obesity in children are available worldwide, but most of them are applied at the moment a child is already overweight.

In this thesis we analyzed the longitudinal growth data of height and weight in a healthy Dutch population to detect the start of becoming obese in a better way. Based on these data, we created a prediction model to detect the risk on obesity at a moment a child has still a healthy weight. The use of the prediction model can be an important tool in the Youth Health Care Practice to prevent obesity.

A risk group for development of obesity is children born small for gestational age (SGA). In this thesis we investigated the growth and change in body composition of SGA children, treated with recombinant human growth hormone therapy (rhGH). The results of this study give more information in the change of body composition of SGA children and thereby in the development of obesity.

In the second chapter, we explored whether the trend of becoming obese already starts during the prenatal period and whether the increase in weight in children is related to a secular trend in height during the last 80 years. Over the last decades the improved condition in Western society led indeed to a tendency for children to increase in height, but also in weight at all ages. We investigated if this secular trend in height and weight is already visible during intrauterine growth. For this purpose we compared growth data of three prenatal growth studies, performed in The Netherlands in the period between 1970 and 2007. No differences between birth weights were found for these years. In postnatal data during that period, increasing weight, height and Body Mass Index (BMI) in both boys and girls were visible, known as the secular trend. The increase in weight starts from five years onwards. The secular trend in height starts from the age of two and a half years onwards in both boys and girls. In conclusion, no prenatal secular trend could be 
detected in The Netherlands. Postnatal, the secular trend is obvious for weight, height and BMI.

In the third chapter, we explored whether short term changes in body composition, measured by total body water (TBW), as a result of rhGH treatment could be used to predict its growth effect after one year in children with growth hormone deficiency (GHD) and SGA children. TBW is the volume of water in the human body. The Deuterium TBW method evaluates shifts from fat mass (FM) to fat-free mass (FFM) by measuring TBW. We investigated data of 88 GHD children and 99 SGA children who started treatment with rhGH. TBW and height were measured. After one year patients were divided into adequate and inadequate responders. In GHD and SGA children a sensitivity of $87 \%$ and $53 \%$ resp. and a specificity of $58 \%$ and $83 \%$ resp. were found. The positive predictive values for GHD and SGA children are $73 \%$ and $90 \%$ resp. The negative predictive values are $75 \%$ and $32 \%$ resp. We state that changes in body composition data measured by TBW are a valuable tool to correctly predict the growth effect after one year in 75\% of the GHD children, treated with $\mathrm{rhGH}$, and are only useful in SGA children when the change in TBW is above the cut off value of $0.7 \mathrm{l} / \mathrm{m}^{2}$.

In the fourth chapter, we investigated the growth pattern, expressed as BMI and weight for height values of SGA children, treated with rhGH treatment. It is known that the majority of SGA children show an accelerating weight gain, but no accelerating length gain. Researchers suggest that low birth weight followed by rapid weight gain during early postnatal life is associated with long-term risks for central obesity. Those SGA children who not correct their length are treated with rhGH. Already at an early age both the GHD and the SGA children show abnormalities in body composition. While GHD children show an increased total body fat, SGA children show a reduced body fat percentage. A previous nationwide study showed that treatment with rhGH barely changed the body composition, measured by the Deuterium total body water dilution method in SGA children. The mean change in BMI after 1 year of rhGH treatment is $0.00 \mathrm{~kg} / \mathrm{m}^{2}$. The mean change in weight for height (SDS), after 1 year of rhGH treatment is 0.17 SDS. Apparently, BMI and weight for height of SGA children change during the first year of rhGH treatment, but only relative. Though, rhGH therapy does contribute to the prevention of the metabolic syndrome in SGA children, becauses it results in a shift in body composition towards an increase in FFM.

In the fifth chapter, we describe the creation of a prediction model for the development of obesity in childhood. This model is based on data of the Dutch longitudinal growth study, collected in 1995-1999, by Gerver et al, to estimate the change in Ponderal Index (PI) and BMI during the first four years of life. It became clear that the PI during the first year, as well as the BMI from the age of 1 year onwards, is changing for most children. This phenomenon can be partly ascribed to the regres- 
sion to the mean. A prediction model was developed to estimate the growth pattern of infants. Based on the individual growth patterns, we could estimate a PI or BMI after a certain period of growth by using formulas representing the "normal" growth of a child. If the actual growth pattern of an individual child does not fit into the expected growth pattern, intervention is needed to prevent obesity later on and thereby reduce the risk of the metabolic syndrome. Multiple local and national health programs are focused on reducing the incidence of obesity. Lots of these programs are focused on dietary and exercise advices. Apparently these programs are not effective enough. Moreover, most children are presented to the youth health care practitioner at the moment their weight is already outside the normal range. Once overweight or obesity is present in children, it is very difficult to solve the obesity problem. Therefore, we created this prediction model to detect the tendency of becoming overweight in childhood at a moment a child has still a healthy age. This model can be used, in the regular preventive health care program, coordinated by the Youth Health Care, in early childhood, to detect whether the growth of a child still fits within the expected range of growth and thereby to detect if a child is at risk to develop obesity.

In the sixth chapter, we applied the prediction model to an overweight and nonoverweight group to test our hypothesis. Therefore, data were retrospectively collected from child records of 120 children, born in 2002, who developed overweight at the age of 5 years. As a control group, data of 120 children born in 2002 in the same region were collected, who did not develop overweight or obesity at the age of 5 years. Based on longitudinal data, the expected value of the Ponderal Index $\left(\mathrm{PI}_{\mathrm{e}}\right)$ at a certain age until the age of 1 year, depending on the child's starting position at birth was calculated. According to our hypothesis, a child is at risk for overweight at the age of 5 years, if the measured $\mathrm{PI}$ value $\left(\mathrm{PI}_{\mathrm{m}}\right)>\mathrm{PI}_{\mathrm{e}}+2 \mathrm{SD}$.

We compared the prediction model with 2 other methods to estimate (ab)normal growth of children; The weight for length growth chart and the PI calculation. It appears that our prediction model is the best predictor for overweight at the age of 5 years.

By using this prediction model, we are able to estimate the growth pattern of an infant. If the actual growth pattern of the infant does not fit into the expected growth, intervention may be needed to prevent abnormal growth. By implementing the prediction model in the electronic child record, health care practitioners could use this model in preventing overweight in children at an early age in an easy way. Especially in children overweight has to be prevented, because overweight and its co-morbidities will be one of the biggest health- and social care problems and costs in the future. 
In the seventh chapter, the results are put into perspective. We discussed the position of our results within the existing knowledge about the prevention of obesity in childhood.

\section{Samenvatting}

Obesitas op kinderleeftijd is tegenwoordig een van de grootste problemen in de gezondheidszorg en zal dit ook in de toekomst blijven. Het metabool syndroom, gekenmerkt door centrale obesitas, hypertensie, verhoogde plasma glucose spiegels, hoge serum triglyceriden en lage high-density cholesterol (HDL) spiegels, is een van de gevaarlijke comorbiditeiten van obesitas. Ook gewrichtsproblemen en psycho-sociale problemen komen veel voor. Het idee dat de oorsprong van het metabole syndroom gelegen is in de vroege levensfase, is gebaseerd op de hypothese van Barker, die veronderstelt dat ondervoeding in de baarmoeder het metabolisme permanent verandert. Gedurende de laatste decennia neemt de prevalentie van obesitas op kinderleeftijd toe. Daarbij stijgt het risico op een toenemende prevalentie op volwassen leeftijd. Het is daarom belangrijk om obesitas op jonge leeftijd te voorkomen, bij voorkeur op het moment dat een kind nog een gezond gewicht heeft. Veel preventieprogramma's gericht op obesitas op kinderleeftijd zijn wereldwijd beschikbaar, de meeste hiervan worden echter pas toegepast op het moment dat een kind al overgewicht ontwikkeld heeft.

In dit proefschrift analyseren wij de longitudinale groeidata van lengte en gewicht in een gezonde Nederlandse populatie om het moment waarop obesitas aanvangt beter te detecteren. Wij ontwikkelden een predictiemodel gebaseerd op deze data, om het risico op overgewicht vast te stellen op het moment dat een kind nog een gezond gewicht heeft. Dit predictiemodel is een belangrijk instrument dat in de jeugdgezondheidszorg gebruikt kan worden om obesitas te voorkomen.

Kinderen, die geboren zijn met een te kleine lengte of te laag gewicht (small for gestational age / SGA children) lopen een verhoogd risico om obesitas te ontwikkelen. In dit proefschrift hebben wij de groei en verandering in lichaamssamenstelling van SGA kinderen die behandeld zijn met groeihormoon onderzocht. De resultaten van deze studie geven meer informatie over de verandering in lichaamssamenstelling van SGA kinderen en daarbij in de ontwikkeling van obesitas.

In het tweede hoofdstuk hebben we onderzocht of de trend om overgewicht te ontwikkelen reeds start in de prenatale periode en of de toename in gewicht bij kinderen gedurende de laatste 80 jaren gerelateerd is aan een seculaire trend in lengte. De verbeterde condities gedurende de afgelopen decennia in de westerse samenleving hebben inderdaad geleid tot een toename in lengte bij kinderen, maar ook in een toename in gewicht op alle leeftijden. In dit hoofdstuk bestudeerden wij 
of deze seculaire trend in lengte en gewicht al zichtbaar is gedurende de intrauteriene groeiperiode. Met dit als doel hebben we groeidata van drie prenatale groeistudies, uitgevoerd in Nederland in de periode 1970-2007, vergeleken. Er werd geen verschil tussen geboortegewichten gevonden in deze periode. In de postnatale data gedurende deze periode werd een toename in gewicht, lengte en Body Mass Index (BMI) bij zowel jongens als meisjes waargenomen, bekend als de seculaire trend. De toename in gewicht start vanaf het $5^{\mathrm{e}}$ jaar, de seculaire trend in lengte start vanaf 2,5 jaar bij zowel jongens als meisjes. We concludeerden dat er geen prenatale seculaire trend gedetecteerd kon worden in Nederland. Postnataal is de seculaire trend evident in zowel gewicht, lengte als BMI.

In het derde hoofdstuk bestudeerden wij of korte termijn veranderingen in lichaamssamenstelling gemeten op basis van het totale lichaamswater (total body water / TBW), als resultaat van groeihormoonbehandeling, gebruikt kunnen worden om het groei-effect na 1 jaar bij kinderen met een groeihormoondeficiëntie en SGA kinderen te voorspellen. TBW is het watervolume in het menselijk lichaam. De Deuterium TBW methode evalueert verschuivingen van vet massa naar vetvrije massa door middel van het meten van TBW. Wij onderzochten data van 88 kinderen met groeihormoondeficiëntie en 99 SGA kinderen, die behandeld werden met groeihormoon. TBW en lengte werden gemeten. Na 1 jaar werden de patiënten verdeeld in adequate en inadequate respondenten. Bij de groeihormoondeficiënte kinderen en SGA kinderen werd een sensitiviteit van respectievelijk $87 \%$ en 53\% gevonden en een specificiteit van respectievelijk 58\% en 83\% . De positief predictieve waarden voor groeihormoondeficiënte kinderen en SGA kinderen zijn respectievelijk 73\% en 90\%. De negatief predictieve waarden zijn respectievelijk 75\% en $32 \%$. Wij veronderstellen dat veranderingen in lichaamssamenstelling, gemeten door TBW een waardevol instrument zijn om bij 75\% van de groeihormoondeficiente kinderen het groei effect na 1 jaar groeihormoonbehandeling correct te voorspellen. Bij SGA kinderen geldt dit alleen als de verandering in TBW hoger is dan de afkapwaarde van $0,7 \mathrm{l} / \mathrm{m}^{2}$.

In het vierde hoofdstuk hebben wij het groeipatroon, uitgedrukt als BMI en gewicht naar lengte, van SGA kinderen, behandeld met groeihormoon, onderzocht. Het is bekend dat de meerderheid van de SGA kinderen een versnelde gewichtstoename laat zien, maar geen versnelde toename van lengte. Onderzoekers suggereren dat een laag geboortegewicht, gevolgd door snelle gewichtstoename gedurende het vroege postnatale leven geassocieerd is met het lange termijn risico om centraal overgewicht te ontwikkelen. De SGA kinderen waarbij hun lengte zich niet corrigeert worden behandeld met groeihormoon. Groeihormoondeficiënte kinderen en SGA kinderen tonen reeds op jonge leeftijd afwijkingen in hun lichaamssamenstelling. Terwijl groeihormoondeficiënte kinderen een toename in lichaamsvetgehalte laten zien, tonen SGA kinderen een verminderd lichaamsvetgehalte. Een eerdere nationale studie liet zien dat behandeling met groeihormoon de lichaamssamenstel- 
ling, gemeten door de Deuterium TBW methode, nauwelijks verandert in SGA kinderen. De gemiddelde verandering in BMI na een jaar groeihormoonbehandeling is $0.00 \mathrm{~kg} / \mathrm{m}^{2}$. De gemiddelde verandering in gewicht naar lengte (SDS) na een jaar groeihormoonbehandeling is 0,17 SDS. Kennelijk veranderen BMI en gewicht naar lengte van SGA kinderen gedurende het eerste jaar van groeihormoonbehandeling. Dit gebeurt echter alleen in relatieve zin. Toch levert groeihormoontherapie een bijdrage aan het voorkomen van het metabool syndroom in SGA kinderen, omdat het resulteert in een verschuiving in de lichaamssamenstelling: namelijk een toename in vetvrije massa.

In het vijfde hoofdstuk beschrijven wij de ontwikkeling van een predictiemodel voor het ontstaan van obesitas op kinderleeftijd. Dit model is gebaseerd op data van de Nederlandse longitudinale groeistudie, verzameld in 1995-1999 door Gerver, om de verandering in Ponderal Index (PI) en BMI gedurende de eerste vier levensjaren te schatten. Het werd duidelijk dat de PI gedurende het eerste jaar en de BMI vanaf de leeftijd van 1 jaar voor de meeste kinderen veranderen. Dit fenomeen kan deels worden toegeschreven aan regressie naar het gemiddelde. Er werd een predictiemodel ontwikkeld om het groeipatroon van kinderen te in kunnen schatten. Gebaseerd op individuele groeipatronen was het mogelijk een PI of BMI na een bepaalde groeiperiode te kunnen voorspellen op basis van formules die de 'normale' groei van een kind weergeven. Indien het actuele groeipatroon van een individueel kind niet past in het verwachte groeipatroon, zijn interventies nodig om overgewicht op latere leeftijd te voorkomen en hierbij het risico op het metabool syndroom te verminderen. Vele regionale en nationale gezondheidsprogramma's zijn erop gefocust de incidentie van obesitas te verminderen. Vele van de programma's richten zich op dieet- en beweegadviezen. Klaarblijkelijk zijn deze programma's niet effectief genoeg. Bovendien worden de meeste kinderen aan de jeugdgezondheidszorgmedewerker gepresenteerd op het moment dat het gewicht al buiten de normale range valt. Als overgewicht of obesitas eenmaal aanwezig is bij kinderen, is het erg lastig om dit probleem op te lossen. Daarom creëerden wij een predictiemodel dat de neiging om overgewicht te ontwikkelen op kinderleeftijd kan detecteren op een moment dat een kind nog steeds een gezond gewicht heeft. Dit model kan gebruikt worden in het reguliere preventieve gezondheidszorgprogramma. De jeugdgezondheidszorg kan dit coördineren om op jonge leeftijd te detecteren of de groei van een kind nog steeds binnen de verwachte groeirange valt. Daarbij kan het risico om overgewicht te ontwikkelen vastgesteld worden.

In het zesde hoofdstuk hebben wij het predictiemodel toegepast op een groep kinderen met en zonder overgewicht om onze hypothese te testen. Hiervoor werden data retrospectief verzameld uit 120 dossiers van kinderen, geboren in 2002, die overgewicht op de leeftijd van 5 jaar ontwikkelden. Als controlegroep werden data van 120 kinderen, geboren in 2002 in dezelfde regio, verzameld die geen overgewicht ontwikkelden op de leeftijd van 5 jaar. Gebaseerd op longitudinale data wer- 
den de verwachte data van de PI (PI expected / $\mathrm{PI}_{\mathrm{e}}$ ) op een willekeurige leeftijd tot de leeftijd van 1 jaar berekend, afhankelijk van de uitgangspositie van het kind bij geboorte. Volgens onze hypothese loopt een kind het risico op het ontwikkelen van overgewicht op de leeftijd van 5 jaar als de gemeten PI waarde (PI measured / $\mathrm{PI}_{\mathrm{m}}$ ) groter is dan $\mathrm{PI}_{\mathrm{e}}+2 \mathrm{SD}$.

Wij vergeleken het predictiemodel met twee andere methoden om de (ab)normale groei van kinderen vast te stellen; de gewicht naar lengte groeicurve en de PI calculatie. Het bleek dat ons predictiemodel de beste voorspeller is voor overgewicht op de leeftijd van 5 jaar. Door het gebruik van dit predictiemodel zijn wij in staat het groeipatroon van een kind te schatten. Indien het actuele groeipatroon van het kind niet in het verwachte groeipatroon past, zijn interventies nodig om abnormale groei te voorkomen. Door het implementeren van het predictiemodel in het elektronische kind dossier, kunnen medewerkers van de jeugdgezondheidszorg dit model op een eenvoudige manier toepassen om overgewicht op jonge leeftijd te voorkomen. Overgewicht moet vooral op kinderleeftijd voorkomen worden, omdat overgewicht en obesitas met al zijn comorbiditeiten een van de grootste problemen zal zijn in de (psycho-sociale en medische) gezondheidszorg en de daaruit voortvloeiende kosten in de toekomst.

In het zevende hoofdstuk wordt er stil gestaan bij de plaats die de resultaten uit dit proefschrift innemen binnen de al bestaande kennis over de preventie van overgewicht op kinderleeftijd. 



\section{DANKWOORD}

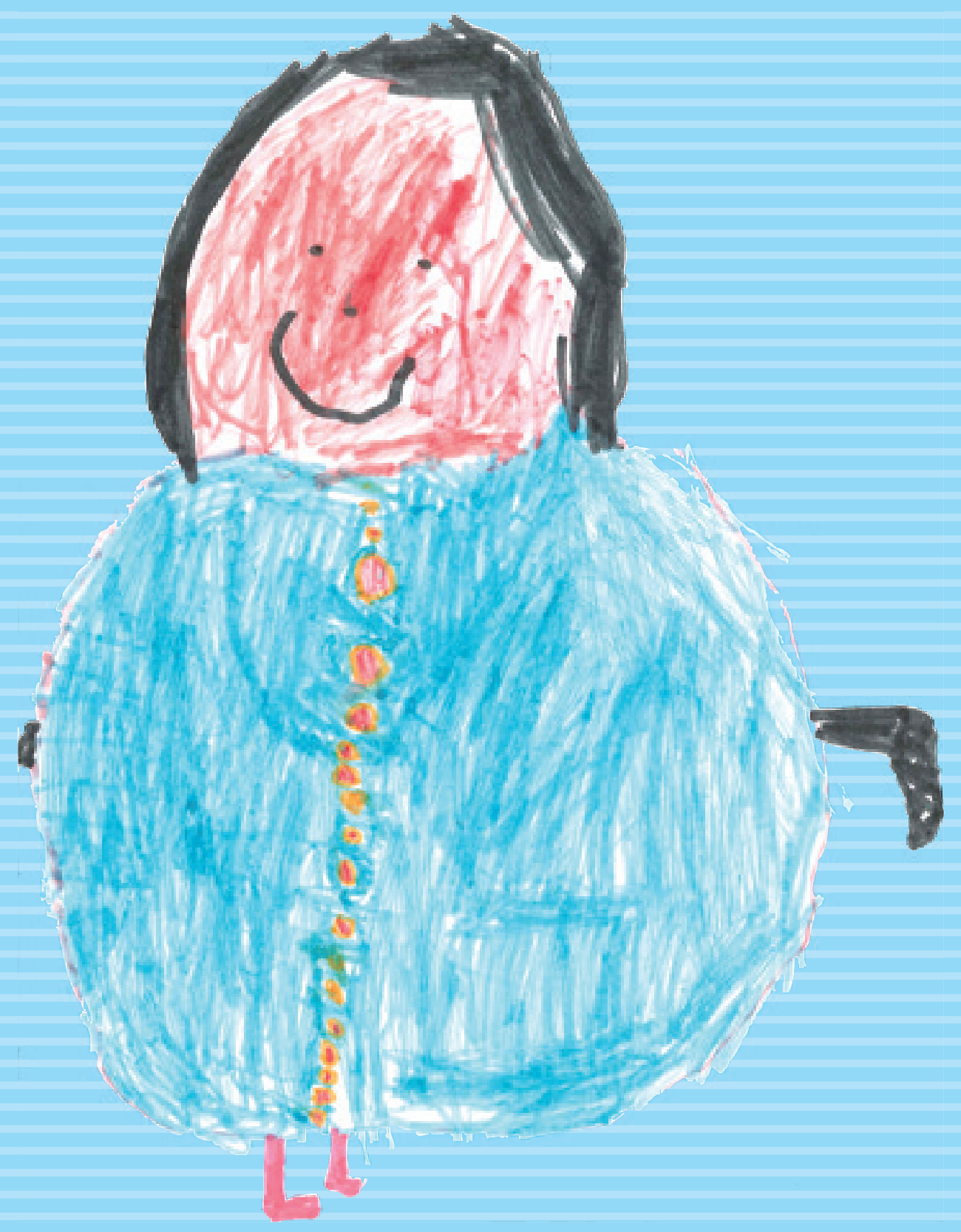




\section{Dankwoord}

Eindelijk is het zover, het is gelukt! In 2008 startte ik met mijn promotietraject en dat resulteerde in dit proefschrift. Zonder de bijdrage en inzet van veel mensen was dit nooit gelukt. Graag wil ik iedereen bedanken die dit proefschrift mogelijk heeft gemaakt.

Ten eerste wil ik graag mijn co-promotor, Dr. W.J.M. Gerver bedanken. Beste Willem Jan, jouw expertise, enthousiasme en steun hebben ervoor gezorgd dat ik dit promotieonderzoek met succes kon afronden. Je was altijd beschikbaar bij vragen of voor overleg. Een reactie op geschreven stukken was er altijd snel. Van jouw kritische blik heb ik veel geleerd. Samen met Angèle was je heel betrokken bij het onderzoek. Ook zorgden jullie voor veel gezelligheid als ik bij jullie op de kamer zat om zaken te bespreken of om stukken te schrijven.

Angèle, bedankt voor jouw goede hulp bij analyses, jouw interesse in zowel werk gerelateerde als privé zaken en natuurlijk je gastvrijheid.

Willem Jan en Angèle, zonder jullie was het afronden van dit promotietraject nooit gelukt. Bedankt voor jullie vertrouwen in mij!

Prof. Dr. L.J.I. Zimmermann, mijn promotor, hartelijk bedankt voor uw hulp, deskundig advies en de belangrijke aanvullingen op mijn proefschrift. Het was erg fijn dat $u$ heel toegankelijk was voor overleg. Merci voor de mogelijkheid om op uw afdeling onderzoek te doen.

Dr. M.A.H.B.M. van der Hoeven, mijn co-promotor, heel veel dank voor de kritische kijk op mijn artikelen, de nuttige tips en het waardevolle commentaar.

Natuurlijk ook veel dank aan Prof. Dr. Ir. M.W.J. Jansen. Beste Maria, dankzij jou kon ik destijds vanuit de Academische werkplaats starten met dit promotietraject. Je hebt mij alle vrijheid gegeven dit traject af te ronden. Bedankt voor jouw enthousiasme, interesse en relevante aanvullingen op mijn artikelen.

Graag wil ik de leden van de beoordelingscommissie, Prof. Dr. J.H.A. Bosma, Prof. Dr. C. Noordam, Prof. Dr. M.S. Westerterp-Plantenga, Prof. Dr. P.J.J. Sauer en Prof. Dr. F.J.M. Feron, als voorzitter, bedanken voor het beoordelen van mijn proefschrift. Bedankt voor jullie inzet en tijd!

Ook wil ik graag Prof. Dr. H.A.M. Neumann en Prof. Dr. P.M. Steijlen, mijn professoren in de Dermatologie, heel hartelijk bedanken. Prof. Neumann, toen ik door $u$ werd aangenomen voor de opleiding tot dermatoloog reageerde $u$ direct positief op mijn promotietraject. Dit moest ik zeker afronden! Combineren met de opleiding Dermatologie hoefde geen probleem te zijn. Bedankt dat u mij deze mogelijkheid hebt gegeven. Prof. Steijlen, ook u stond ervoor open dat ik, toen ik in Maastricht 
mijn opleiding tot dermatoloog vervolgde, dit promotieonderzoek met succes kon afronden. Ik ben jullie beiden hiervoor zeer erkentelijk!

De co-auteurs die hebben meegewerkt aan de artikelen in dit proefschrift wil ik graag bedanken voor hun bijdrage.

Ook wil ik mijn dankbaarheid uiten aan Susanne Hanssen die vele data voor mij heeft ingevoerd. Dank voor je inzet en hulp!

Mijn oud collega's van de GGD Zuid Limburg, van de Academische werkplaats en van de afdeling Sociale Geneeskunde van de Universiteit Maastricht wil ik bedanken voor al hun interesse, hulp en gezelligheid.

Mijn huidige dermatologie collega's wil ik natuurlijk ook graag noemen. Ondanks dat ik op een heel ander vakgebied promoveer, waren jullie altijd erg geïnteresseerd in de voortgang van mijn onderzoek. Merci voor jullie begrip, tips, adviezen en uiteraard alle gezelligheid. Door de fijne sfeer op onze afdeling en de lol die we samen hebben is het soms erg drukke bestaan van AIOS en promovendus heel goed vol te houden.

Lieve vrienden, jullie wil ik super graag bedanken. Jullie zijn altijd geïnteresseerd en betrokken. Jullie zorgen ervoor dat mijn vrije tijd optimaal wordt gevuld met gezellige avonden, borrelen, etentjes, kroegentochten en legendarische weekendjes. Merci voor deze geweldige tijd die ik altijd samen met jullie heb!!

Mijn paranimfen, Tessa en Janice, wil ik in het bijzonder bedanken. Het feit dat jullie me letterlijk bijstaan tijdens een van de spannendste momenten in mijn leven vind ik heel speciaal. Jullie zijn twee geweldige vriendinnen bij wie ik altijd terecht kan en met wie ik altijd veel lol heb... Hopelijk hebben we samen met de andere Muffe Veutsjes nog veel gezellige weekendjes in de Ardennen voor de boeg!

Lieve familie, merci voor jullie interesse en gezellige momenten! Onze familiedagen in het Heuvelland of in de Ardennen zijn altijd super leuk!! Yke en George, jullie wil ik natuurlijk in het bijzonder bedanken voor de correcties van de Engelse teksten.

Mijn schoonfamilie, Tiny, René, Susanne en Bjorn, bedankt voor jullie steun, begrip en gezelligheid. Fijn dat wij altijd welkom zijn bij jullie! Lieve Floor en Lotte, jullie wil ik speciaal bedanken voor het ontwerp van de prachtige kaft en decoratie van mijn proefschrift! 
Felipe, mijn lieve broertje. Jij bent de beste broer die je je kunt bedenken! Je staat altijd voor mij klaar en bent er altijd voor me, of dat nou is op gloriedagen, of tijdens de meest gênante momenten van mijn leven ;) Jij bent er! Wij hebben een super goede band en met jou kan ik het hardste lachen. Merci!!

Papa en mama, mijn lieve ouders, jullie onvoorwaardelijke liefde en steun is voor mij een oersterke fundering. Jullie hebben altijd alle vertrouwen in mij gehad en mij in alle opzichten geholpen. Bij jullie kan ik altijd terecht en dit is een hele fijne en geruststellende gedachte. Jullie zijn mijn grootste voorbeeld, belangrijkste klankbord en adviseurs. De wandelingen, het samen shoppen, de reizen en wintersport met ons gezin zijn voor mij optimale ontspanning! Bedankt voor... alles!!

En ten slotte Xavier, mijn grote liefde! Zonder jou was het afronden van dit promotietraject nooit gelukt. Natuurlijk dankzij jouw liefde, steun, hulp, motivatie, relativeringsvermogen en humor, maar ook op inhoudelijk vlak... Op de middelbare school gaf je me al bijles in de bèta vakken, tijdens de geneeskunde studie was je een grote steun bij het statistiek blok en tijdens dit promotietraject zijn alle tabellen, grafieken en de "finishing touch" aan jou toe te schrijven. Lieve Xavier, ik vind je geweldig, ben super gelukkig met jou en wil dit voor altijd met jou blijven! L'Amour Toujours!! 



\section{CURRICULUM VITAE}

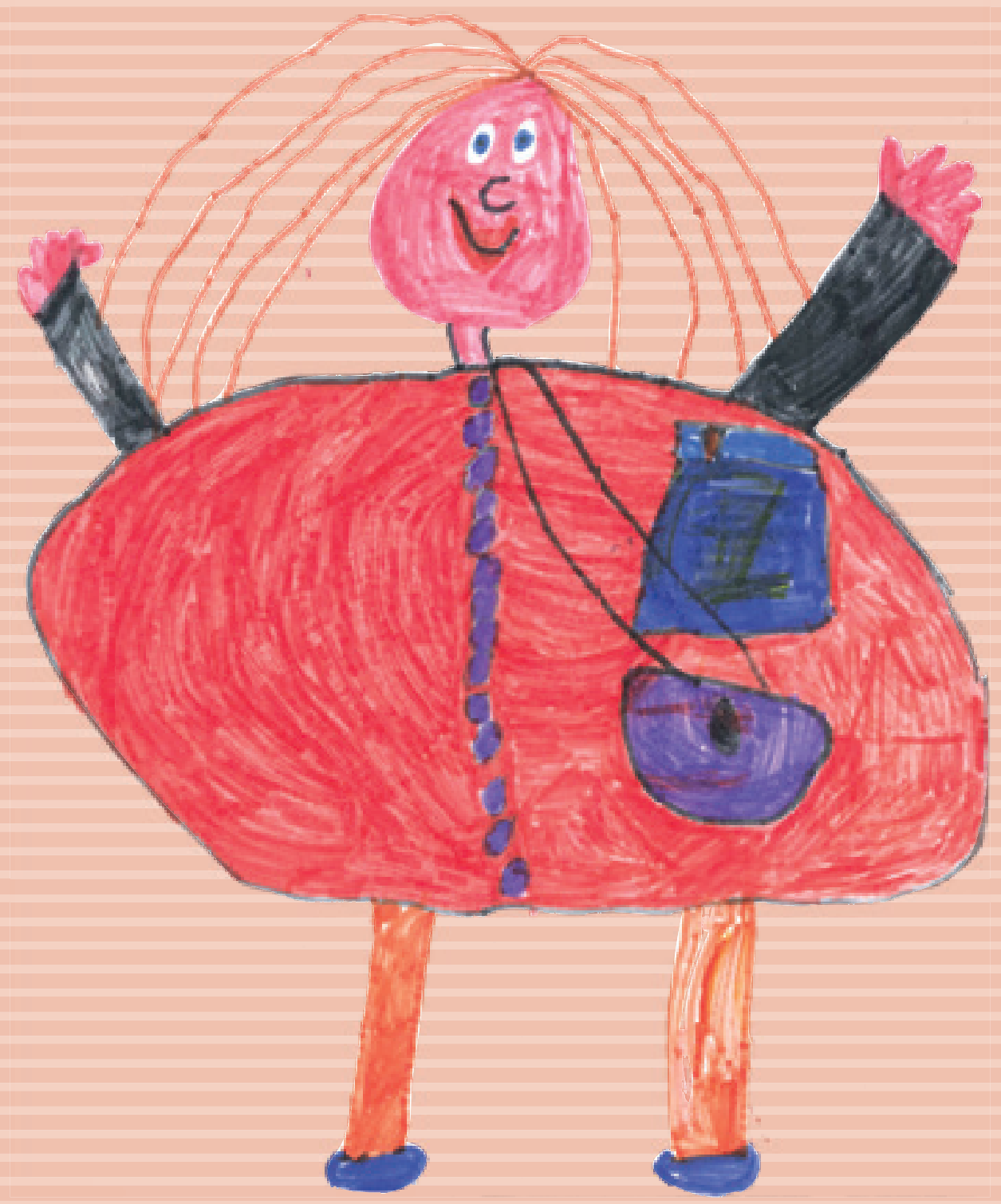




\section{Curriculum Vitae}

Manon Ernst werd op 14 juni 1982 geboren in Heerlen. Zij doorliep het lager onderwijs op basisschool "De Triangel" te Gulpen. In dezelfde plaats behaalde zij in 2000 haar VWO diploma aan het Sophianum.

Aansluitend begon zij haar studie Geneeskunde aan de Universiteit Maastricht, waarbij zij buitenlandse stages liep in onder andere Thailand en Zuid-Afrika. In 2006 verrichte zij wetenschappelijk onderzoek naar porfyrieën in het laboratorium van de afdeling Dermatologie. Het artsexamen werd in 2006 behaald.

Vervolgens werkte zij in de periode 2006-2007 bij Stichting Revalidatie Limburg als arts assistent op de afdelingen Orthopedie en Chronische pijn. Daarna ging zij in 2007 aan de slag als arts Jeugdgezondheidszorg bij de GGD Zuid Limburg. De voornaamste werkzaamheden waren het uitvoeren van het periodieke onderzoek van 5 jarigen en het uitvoeren van risicozorg van kinderen en jeugdigen met onder andere deelname in zorgadviesteams op basisscholen en voortgezet onderwijs. In 2008 startte zij op uitnodiging van de Academische Werkplaats Limburg (Prof. Dr. Ir. M.W.J. Jansen) met het promotietraject "Preventie van overgewicht bij kinderen", bij de Universiteit Maastricht onder leiding van Dr. W.J.M. Gerver. Dit resulteerde in dit proefschrift met Prof. Dr. L.J.I. Zimmermann als promotor en Dr. W.J.M. Gerver en Dr. M.A.H.B.M. van der Hoeven als co-promotoren.

In 2011 besloot Manon zich te specialiseren in de Dermatologie en Venereologie. Zij werd aangenomen voor de opleiding tot dermatoloog in het Erasmus MC te Rotterdam (Prof. Dr. H.A.M. Neumann en Dr. H.B. Thio). Gedurende de eerste 2 jaar was zij werkzaam in het Catharina Ziekenhuis te Eindhoven (Dr. G.A.M. Krekels). In 2013 vervolgde zij haar opleiding tot dermatoloog in het Maastricht Universitair Medisch Centrum (Prof. Dr. P.M. Steijlen). 




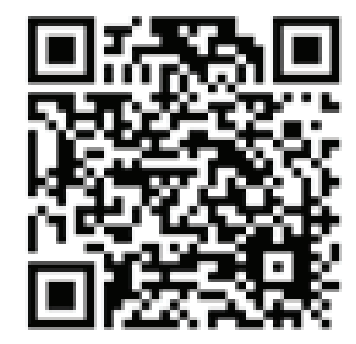

